\title{
Contract Interpretation as the Incidental Issue
}

While clarifying the tribunals' jurisdiction to interpret contracts (Chapter 4) and the relevance of national law for contract interpretation (Chapters 2 and 3), the preceding chapters did not however answer the question of how treaty-based tribunals should approach contract interpretation. Given that many occasions of interpretation are uninformed by national law (Chapter 1), it appears that investment treaty arbitration is in need of a conceptual framework that would ensure treatment of contract interpretation as a legal issue with due regard to the national law governing it. Drawing on the previous chapters, this chapter accordingly goes a step further and suggests a conceptual paradigm that ensures the proper approach to contract interpretation in investment treaty arbitration. This paradigm is based on the concept of the incidental issue as developed in private international law. ${ }^{1}$

The chapter begins by presenting the essential elements of the concept of the incidental issue in private international law. To this end, a number of questions are addressed, including the reasons for conceptualising the incidental issue, the conditions for the incidental issue, the types of incidental issues, the range of approaches for determining the law applicable to incidental issues, and the concept's overall contribution to decision-making in an ordinary context, unrelated to investment treaty arbitration. Prior to engaging in extending the paradigm of the incidental issue to contract interpretation in investment treaty arbitration, the chapter also demonstrates the suitability of approaching a broad range of national law issues as incidental issues in investment treaty arbitration. The observation on the appropriateness and value of the treatment of contract interpretation in investment treaty arbitration as the incidental issue concludes the chapter.

1 In Chapter 3, the international dimension of private international law and international commercial law were relied upon to broaden the scope of international law under investigation. That was necessary to verify whether international law might be viewed as having certain rules capable of substituting national law in contract interpretation. The traditional meaning of private international law used in this chapter relates to a set of primarily national rules regulating conflict of laws and jurisdiction together with some harmonised international rules on the choice of laws and jurisdictions. 
The starting point for understanding the problem of the incidental or preliminary issue ${ }^{2}$ in private international law ('Vorfrage' in German ${ }^{3}$ or 'question préalable' in France ${ }^{4}$ ) is the structure of a particular legal rule. If a legal rule links legal consequences exclusively with facts, in principle, no incidental issues arise, and the courts simply fulfil their duty to establish facts through assessing the available evidence and established legal presumptions. However, when a legal rule ties legal consequences not only with purely factual circumstances but also with legal relationships or statuses, ${ }^{5}$ this opens up a space for incidental issues. Before ruling on the principal issue, courts dealing with such legal rules frequently have to make decisions about these other subsidiary legal issues. For instance, it might be impossible to resolve a dispute relating to the registration of certain shares before deciding on the validity of the agreement about their transfer. Similarly, it might be impossible to decide on the acquisition of nationality (when the matter appears before the court) before deciding on the validity of a marriage. When deciding, the courts may base their decision on established legal presumptions ${ }^{6}$ or in the case of disagreement, they may also need to verify the existence of these legal statuses or relationships.

2 Laura Carballo Piñeiro and Andrea Bonomi, 'Incidental (Preliminary) Question' in Jürgen Basedow and others (eds), Encyclopedia of Private International Law (Edward Elgar Publishing 2017) 912-924; Rhona Schuz, Modern Approach to the Incidental Question (Kluwer Law International 1997); Torben Svenné Schmidt, 'The Incidental Question in Private International Law' (1992) 233 Recueil des Cours de l'Académie de Droit International 305; Wilhelm Wengler, 'The Law Applicable to Preliminary (Incidental) Questions: Chapter 7, Volume III', International Encyclopedia of Comparative Law (Martinus Nijhoff Publishers 1987) 7-5-6o; Allan Ezra Gotlieb, 'The Incidental Question Revisited - Theory and Practice in the Conflict of Laws' (1977) 26(4) International and Comparative Law Quarterly 734, 734-798.

3 Wilhelm Wengler, 'Die Vorfrage im Kollisionsrecht' (1934) 8 Rabels Zeitschrift für ausländisches und internationale Privatrecht 148.

4 Wilhelm Wengler, 'Nouvelles réfléxions sur les "questions préalables"' (1966) Revue critique de droit international privé 165 .

5 If a distinction is drawn between legal relationship and legal status in this context, questions relating to status are more naturally predisposed to be treated as the incidental issue - see Allan Ezra Gotlieb, 'The Incidental Question Revisited - Theory and Practice in the Conflict of Laws' (1977) 26(4) International and Comparative Law Quarterly 734, 764; Rhona Schuz, A Modern Approach to the Incidental Question (Kluwer Law International 1997) 4.

6 Legal presumptions are traditionally addressed from an evidentiary perspective. For a helpful definition of legal presumption, see Robert Kolb, The Elgar Companion to the International Court of Justice (Edward Elgar Publishing 2014) 241-243. For legal presumptions in investment treaty arbitration, see Frédéric G Sourgens, Kabir Duggal and Ian A Laird, Evidence in International Investment Arbitration (Oxford University Press 2018) 121-134. 
For the latter case, the validity of the contract and the marriage in the examples appear as the incidental issues, whereas the decisions on the acquisition of nationality or the registration of shares are the principal issues.

Basing the concept of the incidental issue in private international law on the idea of subsidiarity of certain issues is by no means unique. The distinction is primarily premised on a comprehensive idea of looking at legal issues in disputes through the prism of their centrality to the cause of action. Principal issues are the objects of disputes and trigger desirable solutions. Incidental issues are subsidiary issues to which solutions have to be found for decisions to be made on principal issues. If viewed only from the procedural perspective of their centrality to the principal cause of action, issues that are incidental regularly appear in contexts outside private international law. For instance, principal and incidental issues can also be distinguished in purely domestic settings with no international elements. No complexities would normally arise in characterising and determining the applicable law for these incidental issues - the law that is applicable to the principal issue would also apply to the incidental issue. The only aspect that would matter in this purely domestic context is the order or sequence of the decisions - incidental issues have to be decided first.

What makes incidental issues peculiar enough to justify their appearing as both a concept and a pervasive problem in private international law is undoubtedly the fact that different laws can potentially be applied to them. Instead of being static descriptions of the legal issues because of their centrality to the cause of action, incidental issues in private international law serve as dynamic constructions. The very raison d'être of the incidental issue in private international law is encapsulated in the dilemma concerning the choice of law. An incidental issue becomes the incidental issue in the sense understood in private international law and used here only when it raises a question about applicable law and triggers competitive approaches. This most frequently happens when a foreign lex causae governs the principal issue, upon which lex fori, lex causae or other considerations start to compete in their role of determining the law applicable to the incidental issue. It is therefore no coincidence that the incidental issue in private international law is frequently referred to as the incidental or preliminary question - that is essentially to say, a question about applicable law.

While the 'incidental' in the concept's name may imply a certain peripheral role, in fact it is not uncommon for the choice of applicable law for the incidental issue to influence the final outcome of a case. To use the examples mentioned above, a contract for the sale of shares can be valid under some laws and invalid under others, so the decision to register the shares would be positive or negative. A marriage can be treated as invalid under some laws and valid under 
others, so the decision on nationality would again be positive or negative. The choice of applicable law can be justified by various policy considerations: the general prevailing policy in a particular jurisdiction, deference to the particular nature of the incidental issue, the desirability and undesirability of the likely results, and other factors. Accordingly, the discussion of prevailing approaches to applicable law and their justification, which marks the academic coverage of incidental issues in private international law, is not driven merely by theoretical perfection. There are important practical implications in dealing with the incidental issue in a coordinated and predictable way, rather than on an $\mathrm{ad}$ hoc basis. The incidental issue, accordingly, is a separate legal issue that plays a subsidiary role and raises the question of applicable law to it.

The history behind the theory of the incidental issue, albeit with some disagreement among commentators, can traditionally be traced back to the 1930s. Three German authors are usually named in this context - Wilheim Wengler, George Melchior and Hans Lewald. ${ }^{7}$ Some authors also link the concept with

7 Torben Svenné Schmidt names George Melchior as a pioneer in developing the concept of the incidental issue - see Torben Svenné Schmidt, "The Incidental Question in Private International Law' (1992) 233 Recueil des Cours de l'Académie de Droit International 305, 342. Melchior's role was also recognised at the time by Walter Breslauer - see Walter Breslauer, The Private International Law of Succession in England, America and Germany (Sweet \& Maxwell 1937) 18 and more recently by Laura Carballo Piñeiro and Andrea Bonomi in their entry to the Encyclopedia of Private International Law: Laura Carballo Piñeiro and Andrea Bonomi, 'Incidental (Preliminary) Question' in Jürgen Basedow and others (eds), Encyclopedia of Private International Law (Edward Elgar Publishing 2017) 913. All the commentators mentioned above also praise Wilheim Wengler for the specific focus on the incidental issue that emerged in approximately the same period and continued throughout subsequent years. See also, Friedrich KJuenger, ‘General Course on Private International Law' (1983) 193 Recueil des Cours de l'Académie de Droit International 195. Hans Lewald did not concentrate on incidental issues; nevertheless he used the term 'preliminary issue' that enabled Gotlieb to mention him as one of those who contributed to the development of the theory of the incidental issue in addition to the widely recognised role played by George Melchior and Wilheim Wengler - see Allan Ezra Gotlieb, 'The Incidental Questions Revisited - Theory and Practice in the Conflict of Laws' (1977) 26(4) International and Comparative Law Quarterly 734, 735 (footnote 5). The work of George Melchior covering the incidental issue is George Melchior, Die Grundlagen des deutschen internationalen Privatrechts (De Gruyter 1932) 245-265; three works of Wilheim Wengler covering the incidental issue have been mentioned already, and include Wilheim Wengler, 'Die Vorfrage im Kollisionsrecht' (1934) 8 Rabels Zeitschrift für ausländisches und internationale Privatrecht 148; Wilheim Wengler, 'Nouvelles réfléxions sur les "questions préalables"' (1966) Revue critique de droit international privé 165; Wilheim Wengler, 'The Law Applicable to Preliminary (Incidental) Questions: Chapter 7, Volume III', International Encyclopedia of Comparative Law (Martinus Nijhoff Publishers 1987); the work of Hans Lewald covering the incidental issue includes Hans Lewald, 'Questions de droit international des successions' (1925) 9 Recueil des Cours de l'Académie de Droit International $1,72-75$. 
an Italian scholar and a PCIJ judge, Dionisio Anzilotti, ${ }^{8}$ whose particular contribution to the concept of the incidental issue in the context of public international law is discussed in further detail at a later stage in this chapter. ${ }^{9}$

When the concept of the incidental issue first emerged, it mainly revolved around the matrimonial and family issues that defined the statuses of individuals. This area continues to generate a significant number of examples that fall into the paradigm of the incidental issue. More recently, Rhona Schuz added a new type to what are now classic examples of incidental issues in the family and matrimonial field..$^{10}$ At the same time, incidental issues are not limited to matrimonial or family matters. As early as 1977, Gottlieb assumed that the overall number of cases involving incidental issues in common law jurisdictions was 'in the thousands' and suggested a typology that included, inter alia, issues relating to property, contract and tort. ${ }^{11}$ As the process of the intensification of private relationships with foreign elements continues apace, new examples will inevitably be 'discovered' and 'added to the list' of incidental issues. The sources for this discovery remain inexhaustible, as any type of legal status or legal relationship can potentially become necessary for deciding on the principal issue.

Regardless of the great diversity of incidental issues in private international law, they can all be divided into two large groups - incidental issues of the first order, or the first degree, and incidental issues of the second order, or the second degree. ${ }^{12}$ Incidental issues of the first order are less remote from the principal

8 Dionisio Anzilotti (1867-1950) - Italian lawyer and scholar. Anzilotti taught international law in Italy (1892-1937), and was a judge (1921-46) and President (1928-30) of the PCI . For an overview of Dionisio Anzilotti's academic work and his contribution to international law, see, for instance, Antonio Tanca, 'Dionisio Anzilotti: Biographical Note with Bibliography' (1992) 3 European Journal of International Law 156, 156-162; Jose Maria Ruda, 'The Opinions of Judge Dionisio Anzilotti at the Permanent Court of International Justice' (1992) 3(1) European Journal of International Law 100, 100-122; Giorgio Gaja, 'Positivism and Dualism in Dionisio Anzilotti' (1992) 3(1) European Journal of International Law 123, 123-138.

9 In 1937, Walter Breslauer mentioned Anzilotti's contribution to the development of the incidental issue in private international law (without actually naming the works in which the concept was developed) - see Walter Breslauer, The Private International Law of Succession in England, America and Germany (Sweet \& Maxwell 1937) 18. Anzilotti's name is not mentioned, however, in any encyclopaedia entry on the incidental issue in private international law.

10 Rhona Schuz, A Modern Approach to the Incidental Question (Kluwer Law International 1997) 221-242.

11 Allan Ezra Gotlieb, 'The Incidental Question Revisited - Theory and Practice in the Conflict of Laws' (1977) 26(4) International and Comparative Law Quarterly 734, 761-764.

12 Wilhelm Wengler, 'The Law Applicable to Preliminary (Incidental) Questions: Chapter 7, Volume III', International Encyclopedia of Comparative Law (Martinus Nijhoff Publishers 1987) 7-5. 
issue and their resolution leads directly to the resolution of the principal issue. Incidental issues of the second order are more remote from the main cause of action and their resolution leads to the resolution of other incidental issues. The validity of a marriage and the validity of a share transfer would be incidental issues of the first order, as the principal issues - nationality and share registration - would be directly and immediately dependent on the resolution of these issues. Incidental issues of the second order are those that have to be resolved for decisions about incidental issues of the first order to be made. If, for instance, a decision on the validity of a marriage as an incidental issue to a decision on the acquisition of nationality requires a decision on the validity of a previous divorce, the issue of the divorce's validity would be an incidental issue of the second order, whereas the issue related to the validity of marriage would be an incidental issue of the first order. Similarly, if resolving a dispute involving share registration means that it is first necessary to decide on the capacity of the companies who concluded the sales of the shares before the validity of the transfer can be established, not only does the incidental issue of the first order have to be addressed, but the incidental issue of the second order has to be dealt with first. While the order of remoteness may be potentially limitless, the incidental issues that are necessary for other incidental issues to be resolved are traditionally called incidental issues of the second order, i.e. not of the third or fourth order, etc. This distinction between the incidental issue of the first order and the incidental issue of the second order will be useful for locating the place for contract interpretation in the analysis of a treaty claim at a later stage.

With regard to the key question of the incidental issue - the method for determining the applicable law - there is continuous competition between the two major approaches as to which will play the most decisive role - lex fori or lex causae. ${ }^{13}$ Lex fori, or an independent connection, is the most commonly applied of the conflict of laws rules, both with regard to the principal and the incidental issues. Relying on lex fori removes the need for courts or tribunals to look at conflict of laws rules other than those of the forum. They approach the incidental issue as if it were the principal issue in the forum's jurisdiction; the consistency of an internal domestic order is thus guaranteed because the incidental issue is treated in a similar way in a given jurisdiction, regardless of the context of the proceedings in which it arises. The dependent connection, in contrast, suggests relying on the law applicable to the principal

13 On doctrinal support for lex fori and lex causae see Torben Svenné Schmidt, 'The Incidental Question in Private International Law' (1992) 233 Recueil des Cours de l'Académie de Droit International 305, 342-367. 
issue (lex causae), including its conflict of laws rules, and not on the law of the forum (lex fori) to decide on the law that is applicable to the incidental issue. By insisting that courts or tribunals apply the law of the principal issue (lex causae) to determine the law applicable to the incidental issue, proponents of the dependent connection aim to ensure that courts in different jurisdictions focus on the substance of the principal and incidental issues and not on the forum's conflict of laws rules. Because of this focus on lex causae, the question that constitutes the subject of the incidental issue is treated in a similar way, regardless of the jurisdiction in which it appears. As a result, international, but not necessarily national, harmony is achieved.

The chart below illustrates both approaches.

As seen in Figure 4, the lex fori and lex causae approaches share a common initial stage, and the difference between the two only appears during the last and most crucial stage in the choice of law analysis. Both dependent and independent connections rely on lex fori as the initial stage for deciding on the law applicable to the principal issue. Where the dependent connection is concerned, the same lex fori conflict of laws rules determine the law applicable to the incidental issue, while for the independent connection, it is the lex causae conflict of laws rules that establish which law governs the incidental issue.

Alternative solutions to the above methods for choosing the applicable law for the incidental issue have also been put forward. These either aim merely to mediate between the two approaches by emphasising one of them or to mix

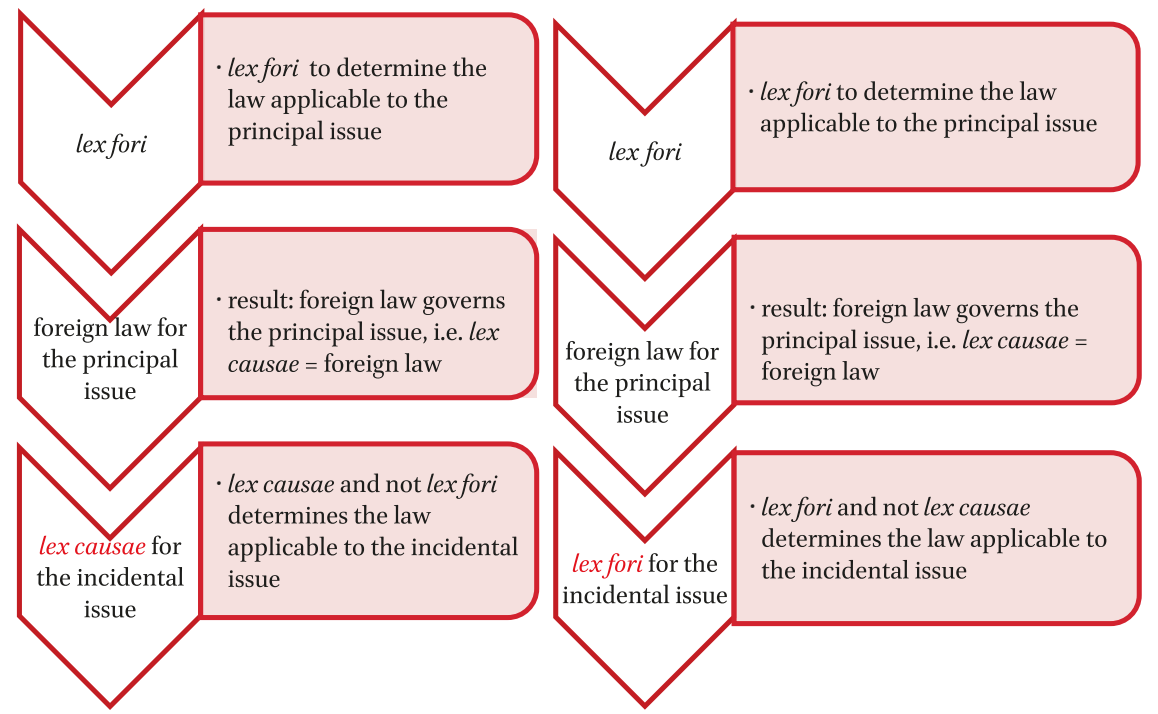

FIGURE 4 Lex fori and lex causae approaches to the incidental issue 
them with various policy-related considerations. The most well-known alternative solution is referred to as a 'result-oriented approach' and advocates a dynamic method instead of a pre-determined single preference for either lex fori or lex causae. ${ }^{14}$ As its name suggests, the result-oriented approach aims to achieve certain outcomes by relying on specific policy reasons ${ }^{15}$ and making a cognisant choice between lex fori and lex causae. Academics disagree as to what constitutes relevant policy: while some authors suggest that the policy can be implied from the substantive rules of lex causae, ${ }^{16}$ others suggest that the relevant policy should clearly come from the forum's conflict of laws rules and cannot be implied from any substantive rules. ${ }^{17}$ Because the prevailing approach is not predetermined, there is a risk of assimilating the result-oriented approach into ad hoc determination, which is not appropriate. Relying on policies as criteria for defining the applicable law implies a normativity that ensures similar results in an unlimited number of similar situations, and thus distinguishes the result-oriented approach from random ad hoc determinations. Despite the method's attractiveness, it has not been sufficiently researched, nor have all the relevant policies that aim to ensure certain results and avoid others been mapped. Similarly to the result-oriented approach, the empirical approach combines and coordinates various approaches, with some preference for lex fori as an underlying method. ${ }^{18}$ Rather than consisting of a single method, the empirical approach provides for a certain framework of considerations that might be taken into account in determining the law applicable to the incidental issue in situations in which the approach described above has failed to function adequately.

Neither of the approaches to the choice of applicable law has gained dominant support. Depending on the jurisdiction and the type of incidental issue, various approaches or combinations thereof can be observed. Gottlieb's

14 See, for instance, Rhona Schuz, A Modern Approach to the Incidental Question (Kluwer Law International 1997) 68-77.

15 The approach takes an analogy from the area of parent-child relationships in which there is frequently an alternative choice of law to guarantee the establishment of parent-child relationships or a child's legitimacy - see Laura Carballo Piñeiro and Andrea Bonomi, 'Incidental (Preliminary) Question', in Jürgen Basedow and others (eds), Encyclopedia of Private International Law (Edward Elgar Publishing 2017) 920.

16 Rhona Schuz, A Modern Approach to the Incidental Question (Kluwer Law International 1997) 68.

17 Laura Carballo Piñeiro and Andrea Bonomi, 'Incidental (Preliminary) Question' in Jürgen Basedow and others (eds), Encyclopedia of Private International Law (Edward Elgar Publishing 2017) 921.

Ibid. 
comment made in early 1977, on various considerations that may influence decisions on the applicable law for the incidental issues, continues to represent the relevant spectrum of values that affect decisions regarding the law currently applicable to the incidental issue:

$[\ldots]$ in every case where there is an incidental question, the specific facts must be looked to and an evaluation made of a wide variety of factors that can influence the results. As we have seen, these factors include the policy of the forum, the notion of public order, the need for consistency among decisions of the forum, the interpretation of the forum's statutes and substantive law, the policies and public order of the foreign State or States concerned in an issue, the construction of the foreign laws, the desire to avoid forum-shopping, the purpose behind the potentially applicable choice-of-law rules, the need to promote international harmony in the decision of various courts involved in a problem, the doctrine of renvoi and fairness and equity. ${ }^{19}$

The existent plurality of views on the choice of law reflects the different policies and underlying values that shape the private international law of a particular state. ${ }^{20}$

Being predominantly about the choice of the applicable law, the concept of the incidental issue also involves other important questions of private international law. The dilemmas that courts or tribunals may face are not necessarily only about the choice of laws, but may relate to the choice of rules. Instead of deciding on the incidental issue, a court or a tribunal may be faced with having to decide on the effect of decisions already made on the incidental issue in a certain jurisdiction. ${ }^{21}$ If a decision has come from a non-judicial body, a recognition rule may come into play and pose a dilemma along with the considerations regarding applicable laws. If the decision has originated in the judiciary,

19 Allan Ezra Gotlieb, 'The Incidental Question Revisited - Theory and Practice in the Conflict of Laws' (1977) 26(4) International and Comparative Law Quarterly 734, 797.

20 For instance, in the Czech Republic, overall preference is given to lex fori, although lex causae may apply under certain conditions if the issue has no relation to the countrysee Monika Pauknerová, Private International Law in the Czech Republic (Kluwer Law International 2011) 69. Furthermore, the same jurisdiction may take different approaches depending on the nature of the incidental issue - this difference is widely explored by the result-oriented approach.

21 Laura Carballo Piñeiro and Andrea Bonomi, 'Incidental (Preliminary) Question' in Jürgen Basedow and others (eds), Encyclopedia of Private International Law (Edward Elgar Publishing 2017) 913-914. 
the issue will turn on pure recognition and will cease to be the incidental question (but see the discussion on less subordinated deference to decisions and awards on contract interpretation of the competent adjudicatory bodies in the context of investment treaty arbitration in Chapter 4).

While the concept of the incidental issue remains largely based on national perspectives, ${ }^{22}$ one can also increasingly observe some inter-state coordination vis-à-vis incidental issues. By way of example, some coordination can be found in intra-EU private international law acts such as Council Regulation (EC) No 44/2001 of 22 December 2000 'On Jurisdiction and the Recognition and Enforcement of Judgments in Civil and Commercial Matters' ${ }^{23}$ Another example of a step towards regulating the incidental issue at the inter-state level may be the Convention of 30 June 2005 on Choice of Court Agreements. Entering into force in $2015,{ }^{24}$ the Convention prohibited party agreement on

22 The concept's development in France and Switzerland is illustrative, though less so than in Germany - see, for instance, Phocion Francescakis, 'Les questions préalables de statut personnel dans le droit de la nationalité' (1958) 23 Rabels Zeitschrift für ausländisches und internationale Privatrecht 466; Paul Lagarde, 'La règle de conflit applicable aux questions préalables' (1960) Revue critique de droit international privé 459; Pierre Lalive, 'Tendances et méthodes en droit international privé: cours général' (1977) 155 Recueil des Cours de l'Académie de Droit International 1; Pierre Mayer, 'Le phénomène de la coordination der orders juridiques étatiques en droit privé' (2007) 327 Recueil des Cours de l'Académie de Droit International 1; Andreas Bucher, 'La dimension sociale du droit international privé' (2009) 341 Recueil des Cours de l'Académie de Droit International 9. For an overview of the contribution of French authors to the development of incidental issues as of 1992 see also Torben Svenné Schmidt, 'The Incidental Question in Private International Law' (1992) 233 Recueil des Cours de l'Académie de Droit International 305, 305, 358362 . For a bibliography of incidental issues grouped by states as of 1987 see also Wilhelm Wengler, 'The Law Applicable to Preliminary (Incidental) Questions: Chapter 7, Volume III', International Encyclopedia of Comparative Law (Martinus Nijhoff Publishers 1987) 3637. Wilheim Wengler in particular provides examples of academic works from Argentina, Canada, Czechoslovakia (a single country at that time), France, Germany, Italy, Japan, the Netherlands, Portugal, Romania, Spain, Denmark, Sudan, Switzerland, the United Kingdom and the United States.

23 For an extensive overview of publications, albeit only in the German language, see footnote 5 in Susanne L Goessl, 'Preliminary Questions in EU Private International Law', (2012) 8(1) Journal of Private International Law 63. Some enactments in private international law in EU expressly provide for treatment for certain aspects of incidental issues. For instance, Article 33 (3) of Council Regulation (EC) No 44/2001 of 22 December 2000 on jurisdiction and the recognition and enforcement of judgments in civil and commercial matters' provides: 'If the outcome of proceedings in a court of a Member State depends on the determination of an incidental question of recognition that court shall have jurisdiction over that question.'

24 As of 13 June 2021, there are 37 contracting parties to the Convention on Choice of Court Agreements 2005 - Hague Conference on Private International Law, '37: Convention of 
the resolution of certain issues as principal objects in courts, while permitting the courts chosen by the parties to deal with these issues whenever relevant as incidental or preliminary issues. ${ }^{25}$ Given the broad harmonisation between various states in respect to conflict of laws issues at an international level, ${ }^{26}$

30 June 2005 on Choice of Court Agreements' <www.hcch.net/en/instruments/conventions/status-table/?cid=98> last accessed 25 June 2021.

25 Article 2 (2) of the Convention on Choice of Court Agreements 2005 excludes the following matters from the issues the parties may agree to refer to a chosen court: ' $(a)$ the status and legal capacity of natural persons; (b) maintenance obligations; (c) other family law matters, including matrimonial property regimes and other rights or obligations arising out of marriage or similar relationships; $(d)$ wills and succession; (e) insolvency, composition and analogous matters; $(f)$ the carriage of passengers and goods; $(g)$ marine pollution, limitation of liability for maritime claims, general average, and emergency towage and salvage'. At the same time paragraph 3 enables the courts to deal with the excluded matters as the incidental issue: 'Notwithstanding paragraph 2, proceedings are not excluded from the scope of this Convention where a matter excluded under that paragraph arises merely as a preliminary question and not as an object of the proceedings. In particular, the mere fact that a matter excluded under paragraph 2 arises by way of defence does not exclude proceedings from the Convention, if that matter is not an object of the proceedings.' While defining the incidental issues, the Convention on Choice of Courts Agreements 2005 does not clarify how the incidental issues should be addressed, leaving this to the national regulations of the relevant fora. The Convention helpfully clarifies that decisions on the incidental issues do not bear res judicata effect.

26 Harmonisation is particularly noticeable in three regions: European Union, Commonwealth of Independent States (CIS) and Latin America. Since 1980, the conflict of laws rules in the EU have experienced serious unification resulting in the Convention 80/934/EEC on the Law Applicable to Contractual Obligations (Rome Convention) (signed 19 June 1980, entered into force 1 April 1991). In 2008, Regulation (EC) No 593/ 2008 of the European Parliament and of the Council of 17 June 2008 on the law applicable to contractual obligations (Rome I) superseded the Rome Convention. The Rome I Regulation is applicable to all EU member states apart from Denmark. Denmark is still regulated by the Rome Convention. The conflict of laws regulation of non-contractual obligations also benefited from a harmonised regulation - Regulation (EC) No 864/2007 of the European Parliament and of the Council of 11 July 2007 on the law applicable to non-contractual obligations (Rome II) (applicable to all EU member states apart from Denmark). It should be noted that intra-EU regulation on conflict of laws is considered supra-national, and not really international in the strictest sense. For coordination in private international law in the cIs region see the Agreement on Settlement of Disputes Related to Commercial Activity - the Kiev Agreement (signed 20 March 1992, entered into force 19 December 1992); the Convention on Legal Aid and Legal Relations in Civil, Family and Criminal Cases - the Minsk Convention (signed 22 January 1993, entered into force 19 May 1994) and the Convention on Legal Assistance and Legal Relations in Civil, Family and Criminal Matters - the Chisinau Convention (signed 7 October 2002, entered into force 27 April 2004). See also, Eugenia Kurzynsky-Singer, 'Commonwealth of Independent States and Private International Law' in Jürgen Basedow and others (eds), Encyclopedia of Private International Law (2017) 397-452. For coordination in private international 
other examples of inter-state coordination with respect to incidental issues can be expected.

The ways in which the concept of the incidental issue can be transplanted into investment treaty arbitration in a theoretically stringent, comprehensive and practical manner, as well as its contribution, are discussed later. As far as the incidental issue's contribution to an ordinary (domestic) context beyond investment treaty arbitration is concerned, the concept contributes greater transparency and predictability to decision-making. As recent writings have shown, the conceptualisation of the incidental question in private international law is not (only) a matter of theoretical research, but of practical significance. ${ }^{27}$ Rather than ignoring incidental issues or assimilating them into facts or similar domestic legal substitutes, significant value lies in facing and discussing the controversies surrounding the legal issue in ways that fully acknowledge its nature, role and the relevant competing and overarching policies of a given jurisdiction in determining the applicable law. Relying on the concept of the incidental issue gives the courts the possibility of dealing with the principal question regardless of possible tactical attempts aimed at impeding resolutions by challenging all the subsidiary issues and insisting that they are settled by other competent courts. At the same time, incidental issues do not impede justice, as decisions taken on them would lack any res judicata effect. Should a competent court dealing with an incidental issue as the principal question later reach a decision contrary to the decision adopted in the proceedings in which the issue was incidental, judicial systems contemplate the possibility of review on the basis of the newly discovered circumstances. The alternative to the paradigm of the incidental issue seems to be unpredictability, reflected in random or uncoordinated ad hoc decisions.

law in Latin America see the Inter-American Convention on the Law Applicable to International Contracts (signed 17 March 1994, entered into force 15 December 1996); the Inter-American Convention on Conflict of Laws Concerning the Adoption of Minors (signed 24 May 1984, entered into force 26 May 1988); the Inter-American Convention on General Rules of Private International Law (signed 8 May 1979, entered into force 10 June 1981); the Inter-American Convention on Conflict of Laws Concerning Bills of Exchange, Promissory Notes, and Invoices (signed 30 January 1975, entered into force 16 January 1976); the Inter-American Convention on Personality and Capacity of Juridical Persons in Private International Law (signed 24 May 1984, entered into force 9 August 1992); the Inter-American Convention on Domicile of Natural Persons in Private International Law (signed 8 May 1979, entered into force 14 June 1980).

27 Rhona Schuz, A Modern Approach to the Incidental Question (Kluwer Law International 1997) 68-77; Susanne L Goessl, 'Preliminary Questions in EU Private International Law' (2012) 8(1) Journal of Private International Law 63, 71-76. 


\subsection{National Law Incidental Issues in Investment Treaty Arbitration}

\subsubsection{The Predisposition to Conceptualise Incidental Issues}

Treaty-based tribunals regularly have to decide on a range of national law issues prior to making any principal decision on a treaty claim. This broad exposure to national law issues has resulted in the shape acquired by international investment law throughout its history, which it still retains today. Rather than directly regulating investment activity, international investment law was intended to create treaty guarantees for foreign investors, with international law remedies for treaty violations. ${ }^{28}$ This regime enabled individuals and companies to protect their rights against states at an international level, and thus exposed treaty-based tribunals to thousands of national law issues connected with the status of individuals and companies, their activity and their interaction with state authorities. Although some concepts reached certain autonomy in investment treaty arbitration, ${ }^{29}$ and consensus might be achieved on certain requirements aimed at foreign investors, ${ }^{30}$ the ongoing discussions

28 For a historical account of the emergence of international investment law and investment treaty arbitration that did not attempt to create uniform international substantive regulation for foreign investment activity, see, for instance, Rudolf Dolzer and Christoph Schreuer, Principles of International Investment Law (2nd edn, Oxford University Press 2012) 1-11; Yuliya Chernykh, 'The Gust of Wind:The Unknown Role of Sir Elihu Lauterpacht in the Drafting of the Abs-Shawcross Draft Convention' in Stephan W Schill and others (eds), International Investment Law and History (Edward Elgar Publishing 2018) 241-285.

29 For an autonomous concept of nationality of a legal entity under international law see Orascom TMT Investments S.à r.l. v. People's Democratic Republic of Algeria, ICsid Case No. ARB/12/35, Final Award dated 31 May 2017, para. 266-281; for an autonomous concept of nationality of an individual under international law see David R. Aven and Others v. Republic of Costa Rica, ICsid Case No. UnCT/15/3, Award of the Tribunal dated 18 September 2018, para. 205-215. For interrelations between national and international law in the understanding of the concept of nationality see Christopher F Dugan and others, Investor-State Arbitration (Oxford University Press 2012) 296-299; Organisation for Economic Co-operation and Development, International Investment Law: Understanding Concepts and Tracking Innovations: A Companion Volume to International Investment Perspectives (OECD Publishing 2008) 10-38; Zachary Douglas, The International Law of Investment Claims (Cambridge University Press 2009) 77; Engela C Schlemmer 'Investment, Investor, Nationality, and Shareholders' in Peter Muchlinski and others (eds), The Oxford Handbook of International Investment Law (Oxford University Press 2008) 69-86.

30 Requirements for a foreign investor are directly connected with the possibility for the state to raise a counterclaim. A possibility to introduce a right of a host state to raise a counterclaim has been addressed during the ongoing discussion of the reform of investment treaty arbitration in UNCITRAL. See, for instance, various states' positions in favour of introducing counterclaims presented at the Working Group III Investor-State Dispute Settlement Reform 34th and 35th Sessions (the Secretariat made available the audio file 
over reforms have so far failed to result in any direct regulation of international investment activity as such. ${ }^{31}$ International investment law has made no provision for an entire replacement for national law regulation in any relevant field of foreign investment. ${ }^{32}$ Put simply, international investment law was neither intended to be a self-sufficient autonomous regime, completely disengaged from national law considerations, nor has it become one.

While exposure to national law issues may vary, it occurs at literally every step of the analyses undertaken by treaty-based tribunals. By way of illustration, the legitimate expectations of foreign investors that are protected by international investment law cannot be based exclusively on treaty regulation; they are ingrained by specific national law rights to which international investment law is not directly relevant. As discussed earlier, contracts do not come into existence as a matter of international investment law, nor are they directly regulated by it. Ownership rights do not arise as a result of applying international investment law. Accordingly, issues of contract formation, scope of contractual rights and obligations, contract validity, contract termination, validity of ownership title over property, transfer of the title and many other contractand property-related rights cannot be resolved under the direct application

but not the transcript) - UNCITRAL, 'Meeting Search' <https://uncitral.un.org/en/wor king_groups/3/investor-state > last accessed 25June 2021. For a summary of the discussion of the UNCITRAL Working Group on counterclaims with quotes, see Anthea Roberts and Zeineb Bouraoui, 'UNCITRAL and ISDS Reforms: Concerns about Costs, Transparency, Third Party Funding and Counterclaims' (EJIL: TALK!, 6 June 2018) <www.ejiltalk.org/ uncitral-and-isds-reforms-concerns-about-costs-transparency-third-party-funding-andcounterclaims $>$ last accessed 25 June 2021. See also Eric De Brabandere, who suggests that treaty-based tribunals accept 'in principle' the possibility of counterclaims, although acknowledges a lack of consistency - Eric De Brabandere, 'Human Rights Counterclaims in Investment Treaty Arbitration' (2017) 5o(2) Revue Belge de Droit International 591. For earlier material on asymmetry in ISDS and the need for counterclaims, see, for instance, Andrea K Bjorklund, 'The Role of Counterclaims in Rebalancing Investment Law' (2013) 17 (2) Lewis \& Clark Law Review 461, 461-48o; Christina L Beharry and Melinda E Kuritzky, 'Going Green: Managing the Environment Through International Investment Arbitration' (2013) 30(3) American University International Law Review 383, 407-411.

31 As of 25June 2021, the reform discussion is still ongoing in UNCITRAL. The efforts are concentrated on procedural aspects of investment treaty arbitration. All updates are available here <https://uncitral.un.org/en/working_groups/3/investor-state > last accessed 25 June 2021.

32 There is, however, an alternative view on the effect of international investment law that is replacing national law regulation. For a recent analysis covering the effect of international investment law on contract law, corporations, property and IP see Julian Arato, 'The Private Law Critique of International Investment Law' (2019) 113 (1) American Journal of International Law 1. See also the discussion on the dogmatic understanding of some contractual provisions in investment treaty arbitration in Chapter 4. 
of international investment law. Furthermore, administrative, licensing and other state regulatory activities that raise certain legitimate expectations or intervene in them do not come into existence on the basis of treaty provisions either, but are also subject to national law regulation.

In addition to the national law issues that directly trigger investment treaty protection, it is possible to identify infinite other peripheral national law issues that necessarily appear before treaty-based tribunals. As evidenced by Chapter 1, there could be various contract-related aspects that stem not from investment contracts but arise under assignment agreements, settlement agreements, guarantees, suretyship, etc. The questions pertaining to their formation and the scope of rights and obligations under these contracts, as well as their termination and validity, may be equally necessary for a decision on a treaty claim. Investment treaty arbitration also regularly decides on a range of classical incidental issues, the most characteristic examples including determination of the legal regime applicable to immovable property, ${ }^{33}$ the legal regime applicable to shares, ${ }^{34}$ the legal regime applicable to the calculation of interests ${ }^{35}$ and the legal regime applicable to power of attorney. ${ }^{36}$

Treaty-based tribunals' exposure to national law issues is further reinforced by the absence, as a rule, of a general requirement to exhaust local remedies. ${ }^{37}$

33 Lion Mexico Consolidated L.P. v. United Mexican States, ICSID Case No. ARB(AF)/15/2, Decision on Jurisdiction dated 30 July 2018, para. 226-227, 232.

34 Talsud S.A. v. The United Mexican States, ICSID Case No. ARв(AF)/04/4, Award dated 16 June 2010, para. 5-28; Gemplus S.A., SLP S.A., Gemplus Industrial S.A. de C.V. v. The United Mexican States, ICSID Case No. ARB(AF)/o4/3, Award dated 16 June 2010, para. 5-28; Urbaser S.A. and Consorcio de Aguas Bilbao Bizkaia, Bilbao Biskaia Ur Partzuergoa v. The Argentine Republic, ICSID Case No. ARB/O7/26, Decision on Jurisdiction dated 19 December 2012, para. 251, 281.

35 Swembalt $A B$, Sweden v. The Republic of Latvia, UnCitral, Decision by the Court of Arbitration dated 23 October 200o, para. 44-49.

36 Ambiente Ufficio S.p.A. and others v. Argentine Republic, ICSID Case No. ARB/o8/9, Decision on Jurisdiction and Admissibility dated 8 February 2013, para. 232-254.

37 See, for instance, Christopher F Dugan and others, Investor-State Arbitration (Oxford University Press 2011) 367-395 and Jonathan Bonnitcha, Lauge N Skovgaard Poulsen and Michael Waibel, The Political Economy of the Investment Treaty Regime (Oxford University Press 2017) 67-68. Because the absence of a requirement on exhaustion of local remedies is continuously criticised, it is not surprising that reintroducing the requirement on exhaustion local remedies appears on the agenda for the ongoing discussion of the reform in investment treaty arbitration - see, for instance, UNCTAD report on reform options dated 12 June 2017, reproduced in United Nations Commission on International Trade Law, 'Settlement of Commercial Disputes. Investor-State Dispute Settlement Framework Comments from International Intergovernmental Organizations. Addendum' (United Nations Commission on International Trade Law, Fiftieth Session Vienna, 3-21 
With a few exceptions, ${ }^{38}$ foreign investors are not required to exhaust local remedies before applying to investment treaty tribunals. The fact that there is no such rule not only means that it is possible to obtain investment protection at an international level when there has been no denial of justice - a natural outcome of the requirement for exhausting local remedies - but also that treaty-based tribunals themselves primarily make decisions on a broad range of national law issues that the local legal system does not resolve conclusively. The broader protection that is not limited to the denial of justice provided to foreign investors thus implies greater autonomy for treaty-based tribunals in dealing with relevant national law issues. At the same time, even if there were a requirement of exhaustion of local remedies, it could not exclude a necessity for a treaty-based tribunal to decide on various subsidiary issues.

The concept of the incidental issue, if modelled on the parallel concept in private international law, inevitably has to deal with a question or dilemma regarding the law applicable to such issues. Treaty-based tribunals' intensive engagement with national law issues naturally and inevitably poses this question on the choice of applicable law to them. However, the question that arises in investment treaty arbitration is of a somewhat different complexity from that in the private international law context. Two factors affect it. Firstly, the very question about the choice of applicable law is conditioned by the initial recognition or denial of the normative applicability of national law because it is IIA/public international law which is primarily applicable. Secondly, and more to the point when the choice of applicable law is concerned, international investment law lacks a set of conflict of laws rules that would assist to determine the law applicable to incidental issues, if one accepts the concept.

Indeed, neither of the two sub-systems of the procedural frameworks in which investment treaty arbitration operates - localised and delocalised - provide an easy answer in relation to relevance and the choice of conflict of laws rules. Both systems recognise party autonomy to choose the applicable law ${ }^{39}$ and both encourage an explanation for any tribunal's choice in the absence of

July 2017, A/CN.9/918/Add.7) <https://uncitral.un.org/en/commission> last accessed 26 September 2021.

38 For examples, see Article 8 (2) of Albania-Lithuania BIT (2007) or Article 7 (2) of RomaniaSri Lanka BIT (1981).

39 Article 42 of the ICSID Convention; Article 27 (1) of the SCC Arbitration Rules 2017 as revised in 2020; Article 21 (1) of the ICC Arbitration Rules 2017 and 2021; Article 33 (1) of the UnCitral Arbitration Rules 1976; Article 35 (1) of the UnCitral Arbitration Rules (2010). 
the parties' designation through a requirement regarding a reasoned award. ${ }^{40}$ Neither, however, has lex fori in the strict sense, and thus no predetermined gravity towards certain domestic conflict of laws regulations exists. Regarding lex causae as another alternative typically applied in the context of private international law for defining the choice for the incidental issue, it is primarily a relevant IIA that applies to investment treaty arbitration..$^{41}$ IIAs are typically silent on the choice of law applicable to incidental issues with exceptions to some of them which essentially mirrors Article 42 of the ICSID Convention. ${ }^{42}$

40 Article 47 (1) (i) of the ICSID Arbitration Rules (2006), Article 42 (1) of the sCc Arbitration Rules 2017 as revised in 2020; Article 32 (2) of the ICC Arbitration Rules 2017 and 2021; Article 32 (3) of the uncitral Arbitration Rules 1976, Article 34 (3) of the UnCitral Arbitration Rules (2010).

41 For a comprehensive overview of lex causae in investment treaty arbitration in the form of a book essay see Jean Ho, 'Unraveling the Lex Causae in Investment Claims' (2014) 15(3-4) Journal of World Investment \& Trade 757.

Verifying the IIAs of the countries whose model BITs contain a reference to conflict of laws and thereafter all BITs of their counterparties with a similar reference to conflict of laws, I have been able to identify 372 IIAs with reference to conflict of laws of the host state (Annex X). See, for instance, Article 8 of the Argentina - United Kingdom BIT (1990), Article 8 of the Argentina - France BIT (1991), Article 8 of the Argentina - Sweden BIT (1991), Article 8 of the Albania - China BIT (1993), Article 10 of the Chile - Ecuador BIT (1993), Article 9 of the Argentina - Jamaica BIT (1994), and Article 8 of the Brazil - Chile BIT (1994). Apart from the apparent similarity in the wording, another two factors point to ties of the analysed exceptional provisions in IIAs with the one used by the ICSID Convention. First, the geographical coverage of the analysed BITs enabling application of conflict of laws rules of the host state reflects the coverage of the ICsid Convention. Secondly, over $90 \%$ of IIAs with provisions referring to conflict of laws rules of the host state identify the ICSID as a competent adjudicatory organ for dispute resolution between an investor and a state. The history behind Article 42 of the ICsID Convention confirms its limited operation in enabling another law than the law of the host state. The provision is not normally used as a starting universal point of analysis of conflict of laws in investment treaty arbitration entirely based on domestic conflict of laws regulation of the host state see the International Centre for Settlement of Investment Disputes, 'History of the ICSID Convention' (Volume 1, 1970) 190-191 < https://icsid.worldbank.org/sites/default/files/publi cations/History\%20of\%2othe\%2oICSID\%2oConvention/History\%20of\%2oICSID\%2O Convention\%20-\%2oVOLUME\%2OI.pdf> last accessed 26 September 2021; International Centre for Settlement of Investment Disputes, 'History of the ICSID Convention', (Volume 2-1, ICSID Publication 1968, reprinted in 2009) 569-570 < https://icsid.worldbank.org/sites/ default/files/publications/History\%20of\%2othe\%2OICSID\%2oConvention/History\%2O of\%20ICSID\%2oConvention\%20-\%2oVOLUME\%2oII-1.pdf> last accessed 26 September 2021; International Centre for Settlement of Investment Disputes, 'History of the ICSID Convention' (Volume 2-2, ICSID Publication 1968, reprinted in 2006) 801-803 <https:// icsid.worldbank.org/sites/default/files/publications/History\%20of\%2othe\%2oICSID\%2O Convention/History\%20of\%2oICSID\%2oConvention\%2o-\%2oVOLUME\%2oII-2.pdf> 
Host state conflict of laws, to which Article 42 of the ICSID Convention and some of the IIAs refer, do not have universal application. The provisions of this kind relate only to the principal claim triggered only in situations in which the parties fail to agree on the applicable law for the principal issue. In the absence of a choice being made by the parties, the host state law may be determined as applicable in its totality, including its conflict of laws provisions; however, this does not automatically give host state conflict of laws provisions any predetermined authority (of the kind similar to lex fori) to provide guidance on the choice of law for each and every subsidiary issue that emerges outside the principal claim. Instead of being a universal mechanism for the choice of applicable laws in delocalised proceedings, its DNA was limited to transmission to a third law, i.e. to renvoi, for the principal claim, or lex causae, which as jurisprudence of investment treaty arbitration demonstrates, does not really happen that often, if at all. If a lack of lex fori brings problems with the choice of applicable law comparable with international commercial arbitration, ${ }^{43}$ the public international law nature of investment treaty arbitration poses questions on the choice of applicable law familiar to other public international law courts and tribunals. ${ }^{44}$

last accessed 26 September 2021; Christoph H Schreuer and others, The ICSID Convention: A Commentary (2nd edn, Cambridge University Press 2009) 6o1.

43 Gary Born, for instance, singles out eight categories of various approaches to the choice of applicable law, which include (1) application of the conflicts rules that the tribunal considers 'appropriate'; (2) application of the conflicts rules of the arbitral seat; (3) 'cumulative' application of all conflicts rules of states with a meaningful connection to the dispute; (4) 'international' or 'general' conflicts rules; (5) the conflict of laws rules of the state with the 'closest connection' to the underlying dispute; (6) the substantive law of the state with the 'closest connection' to the underlying dispute; (7) 'direct' application of a substantive law, purportedly without any choice-of-law analysis; and (8) application of the conflicts rules of the parties' nationalities, the place where enforcement of an award may be required, or other sui generis alternatives - see Gary Born, International Commercial Arbitration (2nd edn, Kluwer Law International 2014) 2643.

44 The works of Kurt Lipstein, Wilfred Jenks, and Edvard Hambro appear among the most noticeable studies in respect to conflict of laws analysis in international adjudication in the middle of the last century. For the works of Kurt Lipstein see Kurt Lipstein, 'Conflict of Laws before International Tribunals (A Study in the Relation between International Law and Conflict of Laws)' (1941) 27 Transactions of the Grotius Society 142; Kurt Lipstein, 'Conflict of Laws before International Tribunals (ii)' (1943) 29 Transactions of the Grotius Society 51; Kurt Lipstein, 'The General Principles of Private International Law' (1972) 135 Recueil des Cours de l'Académie de Droit International 9, 97-229; Kurt Lipstein, 'Conflict of Laws before International Tribunals Sixty Years Later' in Jürgen Basedow others (eds), Aufbruch nach Europa. 75 Jahre Max-Plank-Institut für Privatrecht (Mohr Siebeck 2001) 713-723. For the works of Wilfred Jenks relevant for conflict of laws in international adjudication see Clarence Wilfred Jenks, 'The Interpretation and 
The contrast between the nature and regulation of the principal and incidental issues further facilitates singling out national law issues into a separate category. The principal issues are all treaty-centred. They concern the jurisdiction of investment treaty tribunals, the attribution of liability or violations of investment protection standards, and are primarily governed by public international law - international investment law. ${ }^{45}$ The subsidiary national law issues discussed in this section - the legal status of companies, shareholder rights, property rights and contractual rights - are all governed by national law. While many subsidiary issues - depending on a claim - can also under different circumstances appear as the principal issue in the pure private international law context of domestic or cross-border litigation, incidental national law issues will never appear as the principal issue in the investment treaty arbitration context. It is this contrast that further facilitates conceptualising national law issues in investment treaty arbitration.

Application of Domestic Law by the Permanent Court of International Justice', (1938) 19 British Year Book of International Law 67, 95-97; Clarence Wilfred Jenks, The Common Law of Mankind (Stevens 1958) 1414. For the work of Edvard Hambro see Edvard Hambro, 'The Relations between International Law and Conflict Law' (1962) 105 Recueil des Cours de l'Académie de Droit International 1, 48. For early inquiry on interrelations between private international law and public international law viewed primarily from conflict of laws rules, see John R Stevenson, 'The Relationship of Private International Law to Public International Law' (1952) 52(5) Columbia Law Review 561, 561-588; for a recognition of the limits in national rules on conflict of laws and a call for public international law solutions for conflict of laws rules in 1975, see Fausto Pocar, 'Public International Law Solutions for Conflict of Laws Problems', (1975) 1 Italian Yearbook of International Law 179, 179-191. For a fuller and more up-to-date picture of the role of the PCIJ and the ICJ in developing conflict of laws rules, see Hans van Loon and Stéphanie De Dycker, 'The Role of the International Court of Justice in the Development of Private International Law' in Randall Lesaffer and others (eds), Mededelingen van de Koninklijke Nederlandse Vereniging voor Internationaal Recht - Nr. 140 - One Century Peace Palace, from Past to Present (T.M.C. Asser Press 2013) 73-119.

45 As discussed in Chapter 4, some authors, like Anthony Sinclair, Stanimir Alexandrov, James Mendenhall, Campbell McLachlan, Laurence Shore and Matthew Weiniger recognise that treaty-based tribunals may consider pure contract-based claims on the basis of a broad dispute resolution clause in a relevant IIA or express reference to investment contracts/agreements in a relevant IIA. See Anthony Sinclair, 'Bridging the Contract/ Treaty Divide' in Christina Binder and others (eds), International Investment Law for the 21st Century: Essays in Honour of Christoph Schreuer (Oxford University Press 2009) 9495; Campbell McLachlan and others, International Investment Arbitration: Substantive Principles (2nd edn, Oxford University Press 2017) 106, 154; Stanimir Alexandrov and James Mendenhall, 'Breach of Treaty Claims and Breach of Contract Claims: Simplification of International Jurisprudence' in ArthurW Rovine (ed), Contemporary Issues in International Arbitration and Mediation: The Fordham Papers (Brill/Martinus Nijhoff 2014) 30-33. 
Finally, the suitability of any concept depends on how well it can be integrated into a particular framework. The fact that the incidental issue paradigm can be smoothly integrated into the investment treaty arbitration framework creates further natural predispositions for conceptualising national law issues as incidental issues in investment treaty arbitration. In the context of private international law, the concept of the incidental issue contemplates incidental or preliminary jurisdiction to rule on these issues. If it is assumed that no incidental issues exist in investment treaty arbitration, investment treaty tribunals would be deprived of their incidental or preliminary jurisdiction to decide on the peripheral issues of varying importance that are necessary for a treaty claim, and treaty-based tribunals would therefore have to wait for the competent forums to decide on a wide range of incidental issues. They would be unable to consider whether a certain property had been expropriated because they would first have to establish whether the property came into existence as a matter of national law. They would also be unable to consider whether violations of certain contractual rights triggered standards of investment protection, as they would first have to ascertain whether these contractual rights existed. Finally, they would be unable to ascertain a claimant's legal personality, as that would entail deeming the issue incidental. If focused exclusively on treaty claims, the whole exercise of treaty jurisdiction would be paralysed; in reality, however, investment treaty arbitration works. There is information about numerous pending and concluded proceedings ${ }^{46}$ but substantially fewer about suspended proceedings. ${ }^{47}$ Likewise problematic would be an assumption that treaty-based tribunals consider various national law issues not as the

46 For a regular update see UNCTAD Investment Policy Hub at <https://investmentpolicy. unctad.org/investment-dispute-settlement>.

47 Suspension because domestic courts' exclusive jurisdiction over certain issues is not common. As a rare example, see, for instance, SGS Société Générale de Surveillance S.A. (Claimant) v. Islamic Republic of Pakistan, ICSID Case No. ARB/o1/13, in which the tribunal stayed proceedings to enable the competent court to decide first on the contractual dispute and the scope of contractual rights (the amount due). The most common grounds for suspension are non-payment of advance payments for costs (43(4) of the UNICTRAL Arbitration Rules; 36 (6) of the ICC Arbitration Rules; 24.3 of the LCIA Arbitration Rules; 14(3)(d) of the ICSID Administrative and Financial Regulations), and suspensions peculiar to ICSID arbitration (truncated tribunals, challenges and bifurcation). See also a relevant discussion on an anti-suit injunction, where Emmanuel Gaillard argued that arbitral tribunals should have inherent power to decide how to proceed in the presence of competing proceedings and anti-suit injunctions - Emmanuel Gaillard, 'Reflections on the Use of Anti-Suit Injunctions in International Arbitration' in Loukas A Mistelis and Julian D M Lew (eds), Pervasive Problems in International Arbitration (Kluwer Law International 2006) 203-213. 
incidental issue but as an appeal instance, for as discussed in Chapter 1, a claim before a treaty-based tribunal is an international law claim based on a relevant IIA, and not on the national law as such.

The conceptualisation of incidental issues in investment treaty arbitration is not only supported by arguments that revolve around the subsidiary role of national law issues for the treaty cause of action and a related question on the choice of applicable national law; it is also essentially supported by the concept's smooth integration into the overall investment treaty arbitration framework.

\subsubsection{Scholar Attempts to Conceptualise National Law Issues as Incidental Issues}

Despite the natural predisposition to conceptualise incidental issues in international investment law on the basis of the model of the incidental issue in private international law, this has not been (widely) advocated to date. This does not mean that there is no recognition of certain elements for conceptualising national law issues as incidental issues in academic writings and jurisprudence. There seems to be a broad consensus among scholars that national law matters for certain issues in investment treaty arbitration and that treatybased tribunals should resolve these issues prior to reaching a decision on a treaty claim. While the views may vary as to the precise approach or standard of review for national law issues, scholars working in the international investment law field have no trouble acknowledging that to resolve treaty claims tribunals may need to make preliminary decisions on various contract and property rights, for instance, that have emerged as national law issues. Scholars routinely refer to the questions related to these rights as 'preliminary' or 'incidental' issues, ${ }^{48}$ but it is hard to see if they draw any analogy with the concept of the incidental issue known in a private international law context. That is to say that the incidental issues in their analyses do not form a conceptual category that creates a significant choice of law dilemmas and requires a certain coordinated (pre-determined) approach/decision as to the choice of applicable law. Remoteness from the principal issue, priority in decision-making and the applicability of national law seem to serve as the only criteria for these

48 For instance, Christoph Schreuer, 'Jurisdiction and Applicable Law in Investment Treaty Arbitration' (2014) 1(1) McGill Journal of Dispute Resolution 17, 17-18; Eric De Brabandere, Investment Treaty Arbitration as Public International Law: Procedural Aspects and Implications (Cambridge University Press 2014) 44-45; Ole Spiermann 'Applicable Law' in Peter Muchlinski and others (eds), Oxford Handbook of International Investment Law (Oxford University Press 2008) 112. 
authors' separation of the incidental or preliminary issues. The criteria they use are certainly important, but not sufficiently so as to conceptualise national law issues as incidental issues as understood in private international law. As discussed in the preceding section, the incidental issue raises a question or dilemma in terms of applicable law, and the fact that this component requires a conflict of laws analysis for reoccurring patterns is largely overlooked in academic works.

The scarcity of academic research in the field of conflict of laws analysis in relation to national law in investment treaty arbitration may be attributed to the dominant focus on the role of national law and its interrelations with international investment. The complexity which such interrelations reveal takes all attention and rather a private international law question on the choice of national law is left aside. ${ }^{49}$ Among these works, one can nevertheless distinguish some which may be deemed to endorse the conceptualising of the incidental issue in investment treaty arbitration even without formally distinguishing between principal and incidental issues. In this respect, the works of Monique Sasson and Hege Elisabeth Kjos appear as good examples of an initial step in the direction of conceptualising national law issues as incidental issues in international investment arbitration.

In addressing certain national law rights - such as property rights, shareholder rights and contractual rights - that are protected in investment treaty arbitration, Sasson does not apply the term 'incidental' or 'preliminary' issue to describe their role in the investment treaty context. At the same time, Sasson undoubtedly acknowledges that these rights are subsidiary legal issues subject to national law that must be resolved prior to any decision on the treaty cause of action. To characterise the way national law becomes applicable to these issues, Sasson introduces her own term - renvoi. She borrows the term from private international law, where, as discussed, the concept of the incidental issue also originates, but fills it with a specific meaning. Unlike in private international law, Sasson's renvoi does not contemplate a conflict of laws analysis, but functions as a mechanism that is embedded in the application of

49 Taida Begic, Applicable Law in International Investment Disputes (Eleven International Publishing 2005); Jeswald WSalacuse, The Three Laws of International Investment:National, Contractual and International Frameworks for Foreign Capital (Oxford University Press 2013); Hege Elisabeth Kjos, Applicable Law in Investor-State Arbitration: The Interplay Between National and International Law (Oxford University Press 2013); Monique Sasson, Substantive Law in Investment Treaty Arbitration: The Unsettled Relationship between International Law and Domestic Law (2nd edn, Kluwer Law International 2017); Jarrod Hepburn, Domestic Law in International Investment Arbitration (Oxford University Press 2017). 
international law..$^{50}$ It is this application of international law, or international investment law to be precise, that 'sends back', or requires the direct application of national law. Nor does renvoi complete any analysis of applicable law, as the content of national law has to be 'tested against international law'.51 Because Sasson focuses exclusively on interrelations between international and national law and the application of national law required by the international law framework of the investment dispute, her argument does not cover the question of which national laws are relevant. At the same time her renvoi is an important move towards focusing on the choice of law problem and in denoting the direct and immediate application of a relevant national law to the issues defined here as incidental issues. ${ }^{52}$ In other words, even though the exact choice from among the relevant national laws is not a central issue for Sasson, the need to choose, nevertheless, may be viewed as being implicit in Sasson's renvoi proposition. Given the entire operation of renvoi, it appears that Sasson locates the solution to conflict of laws problems to such incidental issues in public international law.

Like Sasson, Hege Elisabeth Kjos does not use the concept of the 'incidental' or 'preliminary' issue when investigating national law's role in regulating a wide range of issues for investment treaty arbitration. At the same time, Kjos attempts to map a broad variety of occasions on which national law applies independently or in coordination with international law. She anchors her view in relation to the choice-of-law methodology in the distinction between localised (in her words, 'territorialised') and delocalised (in her words, 'internationalised') tribunals. ${ }^{53}$ Kjos acknowledges that delocalised tribunals base their

50 Monique Sasson, Substantive Law in Investment Treaty Arbitration: The Unsettled Relationship between International Law and Domestic Law (2nd edn, Kluwer Law International 2017) 3 .

51 Ibid. 11.

52 In this context, it is interesting to observe that a distinction drawn by Torben Svenné Schmidt between a theory of renvoi and the incidental issue, as understood in private international law, in fact demonstrates that Sasson's renvoi is closer to the incidental issue than renvoi properly understood in private international law. Schmidt connects renvoi with the choice of law to the principle issues whereas the problem of the incidental issue is focused on the choice of applicable law to the subsidiary issues: '... the renvoi theory presupposes that the judge applies the foreign choice-of-law rule to the same main question to which he has already applied his own choice-of-law rule, whereas the incidental question concerns another legal question than the one which was the object of the choice-oflaw rule of the lex fori' - see Torben Svenné Schmidt, 'The Incidental Question in Private International Law' (1992) 233 Recueil des Cours de l'Académie de Droit International 305, 334-335.

53 For a clarification regarding the distinction, see Hege Elisabeth Kjos, Applicable Law in Investor-State Arbitration: The Interplay Between National and International Law (Oxford 
conflict of laws analysis in the international legal order and 'are not bound to apply the choice-of-law rules of the seat' ${ }^{54}$ For localised tribunals, she affirms that choice-of-law methodology is based on the domestic legal order, ${ }^{55}$ primarily on the law regulating arbitration. Engaging with many of the possibilities and limitations of national conflict of laws methodology with respect to the identified national law issues, ${ }^{56}$ Kjos's scholarship also essentially embraces the conceptualising of national law issues as the incidental issue.

The only author who has so far directly acknowledged the relevance of the concept of the incidental issue as developed in private international law for investment treaty arbitration appears to be Zachary Douglas. ${ }^{57}$ To point to a theoretical basis for the concept in private international law, Douglas refers to the cited here works on the incidental issue of Wilheim Wengler and Rhona Schuz as well as on works on categorisation by Arthur Robertson and François Rigaux. ${ }^{58}$ Albeit concisely, Douglas invokes the concept of 'the incidental issue' for property, contract and other private law issues, not only to discuss their subsidiary role vis-à-vis a treaty cause of action as the principal issue, but primarily to deal systematically with a question on applicable law encapsulated in the concept of the incidental issue. To this end, Douglas attempts to formulate specific rules for the choice of applicable national law for these issues. A simple taxonomy of the most common national law incidental issues in investment treaty arbitration can be drawn up on the basis of these rules:

University Press 2013) 18-19. Kjos's distinction between territorialised and internationalised proceedings may raise questions because Kjos attributes a tribunal with a seat - the Iran-USA Claims Tribunal - to a category of internationalised tribunal together with the ICSID on the basis that their mandate is founded in the international legal order. This attribution, it may be suggested, ignores public international law as a foundation for other treaty-based tribunals, conducted under the arbitration rules of international commercial arbitration, which, similarly to the Iran-USA Claims Tribunal, also have a seat.

54 Ibid. 63.

55 Among various considerations, Kjos points to Articles 4 and 5 of the Resolution of the Institute of International Law on Arbitration between States, States Enterprises or State Entities, and Foreign Enterprises dated 12 September 1989 which provide that if parties have not chosen an applicable law, the tribunal shall identify it, taking into consideration various sources including 'the law that would be applied by the courts of the territory in which the tribunal has its seat' - available at <http://www.idi-iil.org/app/uploads/2017/06/ 1989_comp_o1_en.pdf> last accessed on 25June 2021.

56 Hege Elisabeth Kjos, Applicable Law in Investor-State Arbitration: The Interplay Between National and International Law (Oxford University Press 2013) 60-105.

57 Zachary Douglas, The International Law of Investment Claims (Cambridge University Press 2009) 39-150 (of immediate relevance 50-52). 
- the capacity of a legal entity to prosecute the claim is to be decided by lex societatis (Rule 8 in Douglas's book); 59

- the existence of property or the scope of property rights is to be decided by the national law of the host state, ${ }^{60}$ including its private international law rules (Rule 4 in Douglas's book);

- issues relating to contractual obligations, torts or restitutionary obligations are to be approached from the position of the law governing the contract, tort or restitutionary obligation in 'accordance with generally accepted principles of private international law' (Rule 11 in Douglas's book). ${ }^{62}$

Douglas does not seem to view the concept of the incidental issue of private international law as being foreign to international investment law; he regards conceptualising national law issues as the incidental issues in investment treaty arbitration as a result of the direct and rather natural interaction between private international law and public international law. In this regard, private international law does not consist solely of national conflict of laws rules, but also of commonly accepted conflict of laws rules or generally accepted principles of private international law. In the absence of 'generally accepted principles of private international law', Douglas suggests using a comparative approach to try to find common ground in conflict of laws analysis of relevant national laws. ${ }^{63}$ In other words, for Douglas private international law does not serve

59 Ibid. $78-79$.

6o This rule was not drafted for all property-related issues that appear in investment treaty arbitration, but only for property rights that go to the heart of the dispute and come into existence as a matter of host state national law.

61 Ibid. $5^{2-72 .}$

62 Ibid. 9o-94.

63 Ibid. 9o. A comparative approach suggested by Douglas can be traced back to 1941, when conflict of laws before international tribunals received their first substantial discussion. Reacting to Lipstein's paper 'Conflict of Laws before International Tribunals: A Study in the Relation between International Law and Conflict of Laws', émigré German professor Ernst Wolff raised sceptical concerns regarding the capacity of international courts and tribunals to develop an independent set of conflict of laws rules. Instead of a system of rules concerning conflict of laws created by the decisions of international tribunals, Wolff suggested among others that a comparison among potentially relevant conflict of laws considerations in national laws could be a way out of the difficulty generated by a lack of lex fori for international courts and tribunals and a real workable alternative to international rules for conflict of laws - see discussions published together with Lipstein's paper - Kurt Lipstein, Conflict of Laws before International Tribunals: A Study in the Relation between International Law and Conflict of Laws' (1941) 27 Transactions of the Grotius Society 142, 178. (Ernst Wolff should not be confused with another German scholar - Martin Wolff, who published extensively on questions of private international law - Martin Wolff, Private International Law (Clarendon 1945). 
as a source for transplant or analogy, but in its broadest sense, which encompasses national and international dimensions, coordinates directly with public international law to answer the question about the law applicable to incidental issues. This stepping outside the exclusive dominance of public international law (paradigm) and recognising the usefulness of the (possibility for) coordination between private international law and public international law enabled Douglas to arrive at the concept of the incidental issue for investment treaty arbitration. It therefore comes as no surprise that James Crawford praised Douglas's book for displaying 'fluency not only in public international law but also in private international law' and for the author's 'desire to comprehend individual cases and disputes within some overall frame and matrix'.64

Slowly but steadily, considerations pertaining to conflict of laws begin to appear on the agendas of scholars focused on both contract- and treaty-based investment arbitration. Early works on conflict of laws for international adjudication bodies of Wilfred Jenks, ${ }^{65}$ Kurt Lipstein, ${ }^{66}$ and Edvard Hambro ${ }^{67}$ to name but a few create a necessary foundation for them. In addition to the mentioned contemporary works engaging with conflict of laws consideration for investment treaty arbitration of Douglas and Kjos, one can name, for instance, the work of Jan Asmus Bischoff. ${ }^{68}$ A recent initiative of the Institute of International Law may further enhance understanding of conflict of laws in the setting on the international courts and tribunals, including investment treaty arbitration. ${ }^{69}$ The dominance of the public international law perspective

64 James Crawford, Foreword in Zachary Douglas, The International Law of Investment Claims (Cambridge University Press 2009) XXI.

65 Clarence Wilfred Jenks, The Common Law of Mankind (Stevens 1958) 1414; Clarence Wilfred Jenks, 'The Interpretation and Application of Domestic Law by the Permanent Court of International Justice' (1938) 19 British Yearbook of International Law 67, 95-97.

66 Kurt Lipstein, 'Conflict of Laws before International Tribunals (A Study in the Relation between International Law and Conflict of Laws)' (1941) 27 Transactions of the Grotius Society 142; Kurt Lipstein, 'Conflict of Laws before International Tribunals (ii)' (1943) 29 Transactions of the Grotius Society 51, Kurt Lipstein, 'The General Principles of Private International Law' (1972) 135 Recueil des Cours de l'Académie de Droit International 9, 97-229; Kurt Lipstein, 'Conflict of Laws before International Tribunals Sixty Years Later' in Jürgen Basedow and others (eds), Aufbruch nach Europa. 75Jahre Max-Plank-Institut für Privatrecht (Mohr Siebeck 2001) 713-723.

67 Edvard Hambro, 'The Relations between International Law and Conflict Law' (1962) 105 Recueil des Cours de l'Académie de Droit International 1, 48.

68 Jan Asmus Bischoff, 'Conflict of Laws and International Investment Arbitration' (2018) 7(1) European International Arbitration Review 143.

69 In 2017, the Institute of International Law created a commission focused on the choice of law in international courts and tribunals - the Sixth Commission. As of 30 June 2021, the work of the commission is still pending. 
for scholarship on international investment law and investment treaty arbitration and frequent engagement of private international law practitioners in investment treaty arbitration, ${ }^{70}$ may go some way towards explaining the scarcity of academic conceptualisation and the ease one may see in which some of the treaty-based tribunals implement the concept of the incidental issue in their reasoning.

\subsubsection{Other Supporting Considerations (1): Direct Conceptualisation- National Law Incidental Issues before Other Public International Law Courts}

National law issues as incidental issues appear not only in investment treaty arbitration but also in the broader context of international adjudication in the practice of the ICJ (and previously the PCIJ), the ECtHR and various regional international human rights courts, etc. Exclusively applying international law as a principal applicable law, these courts regularly recognise the relevance of national law to certain categories of questions that have a subsidiary role to the principal claim. This engagement with national law comes as a natural consequence of their international jurisdiction and the limited regulatory coverage of international law regulation ${ }^{71}$ and is not opposed to either monist or dualist views on international law or a mixture of the two. The engagement with national law entails a question about the choice of applicable law at various levels and makes the concept of the incidental issue's appearance in

70 On a clash between private and public law perspectives in investment treaty arbitration, see, for instance, Stephan W Schill, 'Public or Private Dispute Settlement? The Culture Clash in Investment Treaty Arbitration and Its Impact on the Role of the Arbitrator' in Todd Weiler and Freya Baetens (eds), New Directions in International Economic Law: In Memoriam Thomas Wälde (Martinus Nijhoff Publishers 2011) 23-44; Stephan W Schill, 'The Public Law Paradigm in International Investment Law' (EJIL: Talk!, 3 December 2013) <https://www.ejiltalk.org/the-public-law-paradigm-in-international-investmentlaw> last accessed 25June 2021; Anthea Roberts, 'Clash of Paradigms: Actors and Analogies Shaping the Investment Treaty System' (2013) 107(1) American Journal of International Law 45 .

71 It may be interesting to observe that in 1938 prior to the emergence of investment treaty arbitration, Clarence Wilfred Jenks noted that the PCIJ engagement with national law was an inescapable natural consequence of its international jurisdiction: '... recourse to domestic law has been a common feature of the experience of other international tribunals to create a strong presumption that the extent to which the Court has been called upon to consider domestic law has not been the result of any unusual series of accidents, but has been simply the inevitable reflection of the complexity of the legal relationships with which international tribunals are ordinarily required to deal' - see Clarence Wilfred Jenks, 'The Interpretation and Application of Domestic Law by the Permanent Court of International Justice', (1938) 19 British Year Book of International Law 67, 89 . 
public international law context, if not absolutely natural, then at least unsurprising. Broadly speaking, the incidental issues encountered by public international law courts and tribunals relate to status, ${ }^{72}$ legality ${ }^{73}$ and validity ${ }^{74}$ under national law. While the degree to which incidental issues and their precise content are dealt with may vary according to the jurisdictional design of international courts, ${ }^{75}$ their particular historical context, ${ }^{76}$ as well as the factual shape and other peculiarities of an individual case, none of the international courts mentioned above have ever been completely immune from the need to decide on them. This application of the incidental issue paradigm in the pure public

72 Barcelona Traction, Light and Power Company, Limited (Belgium/Spain), Second Phase, ICJ Reports 1970, 33-34, para.38; Ahmadou Sadio Diallo (Republic of Guinea v. Democratic Republic of the Congo), Judgment on Preliminary Objections dated 24 May 2007, para. 64-67.

73 For instance, Article 7(1) of the ECHR directly points to the necessity to consider national law: 'No one shall be held guilty of any criminal offence on account of any act or omission which did not constitute a criminal offence under national or international law at the time when it was committed.' Clarifying operation of the provision, Giulia Pinzauti points, among others, to the national-law incidental questions which are necessary to resolve prior to the decision on violation of Article 7: 'The Court's ruling on the alleged violation of the legality principle laid down in Article 7 (principal or primary question), is conditional upon the solution of another question, which is preliminary in nature (question prejudicielle): did the offence of which the applicant was convicted constitute a crime under either national or international law at the time of its commission? To solve that preliminary question the Court obviously has to take into consideration the relevant criminal provisions of the respondent state or, if need be, any international treaty or customary rules on international crimes, depending on the specific substance of the petitum.' - see Giulia Pinzauti, 'The European Court of Human Rights' Incidental Application of International Criminal Law and Humanitarian Law: A Critical Discussion of Kononov v. Latvia' (2008) 6 Journal of International Criminal Justice 1043, 1047. It may be interesting to observe that Wilhelm Wengler, who, as discussed, was among the first to address the incidental issue in a pure private international law context, in 1987 already recognised a (limited) possibility for the incidental issue to trigger application of criminal law. The category of cases which Wengler thus identified related to contract validity, the performance of which may lead to a criminal responsibility - see Wilhelm Wengler, 'The Law Applicable to Preliminary (Incidental) Questions: Chapter 7, Volume III, International Encyclopedia of Comparative Law (Martinus Nijhoff Publishers 1987) 4.

74 Certain German Interests in Polish Upper Silesia (Germany v. Poland) 1925 PCIJ (ser.A) No.6 (Aug.25), p.18 (the case is addressed in more detail below).

75 The extent of exposure to national law issues correlates with the possibility for an individual or company to initiate proceedings. National law issues appear more frequently in the practice of international courts that enable individual standing than in the practice of such courts that solely settle inter-state claims.

76 The nature of national law issues that appear in international court practice can be linked to a particular historical period. For instance, the PCIJ considered more contract-related national law issues than the ICJ. 
international law context accordingly demonstrates its viability as a concept, and thus supports the consideration that reinforces conceptualising national law issues in investment treaty arbitration.

Two early PCIJ judgments in connected cases, one contentious - Certain German Interests in Polish Upper Silesia ${ }^{77}$ - and the other interpretative Interpretation of Judgments Nos. 7 and 8 (Factory at Chorzów) ${ }^{78}$ - are of particular interest here. Not only are these cases among the first that help to illustrate the incidental issue paradigm in a public international law context, but they are both also linked with the name of Anzilotti who served as a judge in both of these cases. ${ }^{79}$ While not attempting to extend Anzilotti's role in enhancing the concept of the incidental issue beyond the private international law context into a public international law setting, it is very tempting to see a connection between his contribution relating to the incidental issue in private international law ${ }^{80}$ and the appearance of the concept, together with its own terminology, in the PCIJ's reasoning in a public international law context. Furthermore, viewing both cases together makes it possible to provide a meaningful response to possible criticism of conceptualising the incidental issue on the basis of national law's role in international law as a question of fact.

Both cases arose from an inter-state dispute between Germany and Poland over the latter's actions regarding German property in Upper Silesia, which Germany claimed contravened the Geneva Convention concerning Upper Silesia. Because the Geneva Convention guaranteed that German nationals' property would not be 'liquidated, Germany, among others, argued that a 1920 Polish law and actions of the Polish treasury replacing Oberschlesische Stickstoffwerke Company as the owner of the Chorzów Factory in the land

77 Certain German Interests in Polish Upper Silesia (Germany v. Poland) 1925 PCIJ (ser.A) No.6 (Aug.25); see also Matthias Hartwig and Ignaz Seidl-Hohenveldern, 'German Interests in Polish Upper Silesia Cases', Max Planck Encyclopedia of Public International Law <https:// opil.ouplaw.com/view/10.1093/law:epil/978o19923169o/law-978o19923169o-e137> last updated May 2011, last accessed 25 June 2021; see also Monique Sasson discussing the case in the context of property rights - Monique Sasson, Substantive Law in Investment Treaty Arbitration: The Unsettled Relationship between International and Domestic Law (2nd edn, Kluwer Law International 2017) 111.

78 Interpretation of Judgments Nos. 7 and 8 (Factory at Chorzów) (Judgment of 16 December 1927) (1927) PCIJ Series A. No.13.

79 Dionisio Anzilotti joined the majority in the Certain German Interests in Polish Upper Silesia (Germany v. Poland) (Merits) and dissented in Interpretation of Judgments Nos. 7 and 8 (Factory at Chorzów).

80 See the discussion on the emergence of the concept of the incidental issue in private international law at the beginning of this chapter and acknowledgement of Anzilotti's role by Walter Breslauer. 
register breached the Convention. Overall, Germany insisted that Poland had undermined Oberschlesische Stickstoffwerke Company's control over the factory and Bayerische Stickstoffwerke Company's possession of licences and patents in breach of the Geneva Convention. Poland explained its actions by insisting that the transfer of factory ownership from the Reich to Oberschlesische Stickstoffwerke Company, on the basis of which Oberschlesische Stickstoffwerke Company became the alleged owner, violated international law, and Poland was therefore entitled by its own law to assume ownership of the factory. Establishing who owned the nitrate factory in Chorzów under the relevant German national law before the 1920 Polish law took effect became critical for the dispute. In other words, to find out whether public international law - the Geneva Convention concerning Upper Silesia had been breached, the PCIJ first had to ascertain who owned the Chorzów Factory - the Reich or Oberschlesische Stickstoffwerke Company - and when this ownership had come into existence. The public international law question depended on the national law question - the incidental question on the existence of property rights.

It is noteworthy that the PCIJ began its consideration by expressly marking analysis as being tied with incidental considerations. The Court observed that it 'will not examine save as incidental or preliminary point, the possible existence of [ownership] rights under German domestic law ...' ${ }^{81}$ That verification implied the consideration of Auflassung as a specific instrument on the transfer of property rights under German law and routines of recording it in the land register together with verification of peculiarities connected to company registration as well. Having ascertained that the factory had been owned by a German company and not the state, the PCIJ ultimately found that Poland had violated the Geneva Convention.

Conceptualising national law as the incidental issue in the context of public international law may face a challenge connected with the treatment of national law as fact. By diminishing the normative implication of national law, the 'traditional' public international law approach essentially factualises not only national law but also issues to which that law applies. The 'factual' approach towards national law coincidentally originated from the respective statement in Certain German Interests in Polish Upper Silesia (Merits) that 'municipal laws are merely facts.' 82 And while Certain German Interests in Polish Upper Silesia (Merits) is associated with the 'factual' approach towards national

81 Certain German Interests in Polish Upper Silesia (Merits) (Judgment No.7 of 25 May 1926) (1926) PCIJ Series A No. 7.

82

Ibid. 19 . 
law, viewed together with the subsequent Interpretation of Judgments Nos. 7 and 8 (Factory at Chorzów) and through the prism of ownership ascertainment, the cases actually support the normative and not the 'factual' approach to national law.

Indeed, if the PCIJ statement is reconciled with the concept of the incidental issue, it becomes clear that the Court did not intend to deprive national law of its normative applicability for each and every aspect of international disputes. By first acknowledging that property rights were to be dealt with as the incidental issue through due regard to German law, and then by reconfirming this approach in the interpretative decision, the PCIJ cannot be perceived as supporting the position that national law is a question of fact in international law. Approaching ownership rights as the incidental issue, on the one hand, and treating national law as a question of fact on the other, are mutually exclusive; the former recognises the normative role of national law and the latter denies it.

The statement regarding national law's factual role should therefore be perceived in the narrow context of the role played by the 1920 Polish law in the case, and not as a universal statement. In Certain German Interests in Polish Upper Silesia (Merits), the PCIJ was not required to apply Polish law; instead the court was asked to assess its implication as a factual matter - whether in breach of international law, or not. The full statement incorporating the 'classical formula' fits this perception:

From the standpoint of International Law and of the Court which is its organ, municipal laws are merely facts which express the will and constitute the activities of States, in the same manner as do legal decisions or administrative measures. The Court is certainly not called upon to interpret the Polish law as such; but there is nothing to prevent the Court's giving judgment on the question whether or not, in applying that law, Poland is acting in conformity with its obligations towards Germany under the Geneva Convention. ${ }^{83}$

Likewise, if the decision on the transfer of the ownership of Chorzów were taken as a government decision instead of a legal decision, the PCIJ statement cited would be equally applicable. What the Court had to do in that context was simply to address the factual side of the matter, and it was therefore quite natural to say that legislative or government decisions, whichever applied,

83 Ibid. 
were to be perceived as questions of fact for the purpose of assessing their compliance with international law obligations. In that context, national law was certainly not viewed through its normative character, but rather through its factual implication for the international law claim.

At the same time, as discussed above, the decision as to whether Polish law complied with its international law obligations under the Geneva Convention was premised on determining the owner of the factory - the Reich or the German company - prior to the adoption of the Polish law. If it was the Reich, the Polish law had complied with its international law obligations; if it was a German company, Poland had violated these obligations. The decision required application of German law, so German law was not treated as a question of fact in this respect; on the contrary, it was approached and applied normatively.

Addressing the case in 1938, Wilfred Jenks already warned against overemphasising the declared approach in Certain German Interests in Polish Upper Silesia on national law as facts. According to Jenks:

The Court has not drawn from this remark the conclusion that municipal laws must be proved as facts in the manner in which foreign law is generally required to be proved in an English court, and in subsequent cases it has clearly passed beyond the line which separates exposition from interpretation. ${ }^{84}$

National law's normative, rather than simply factual, role in respect to the question of ownership, as the incidental issue became crystal clear at a later stage when Germany asked the Court to interpret the judgment. The PCIJ voted by eight to three to support Germany's request and make it clear that recognition of the ownership of the Oberschlesische of the factory in Chorzów was conclusive in the Interpretation of Judgments Nos. 7 and 8 (Factory at Chorzów). While Anzilotti felt compelled to dissent, ${ }^{85}$ the heart of the disagreement between the majority in the PCIJ and Anzilotti lay in the appropriateness of the interpretation and the consequences of a decision on the incidental issue, but not in German law's normative role. One may speculate on the reasons why the PCIJ made the decision on the incidental issue conclusive, ${ }^{86}$ but what is most

84 Clarence Wilfred Jenks, "The Interpretation and Application of Domestic Law by the Permanent Court of International Justice' (1938) 19 British Yearbook of International Law 67,68 .

85 Anzilotti perceived the request for interpretation as going beyond interpretation of the operative part of Judgments No. 7 and 8 and thus impermissible.

86 Among possible reasons for the decision one may potentially name a connected case on indemnity which was pending before the PCIJ at the time - Factory at Chorzów (Merits) 
important is understanding that the need to conceptualise the incidental or preliminary issue and to recognise the relevance of national law to them was rather unquestioned.

Treatment of national law as the incidental issue by other public international law courts and tribunals accordingly demonstrates the suitability of the concept of the incidental issue. Discomfort about approaching national law as a matter of fact and as a result having a more differentiated view on national law beyond merely factual penetrate nowadays various works in the field of public international law and directly or indirectly support the idea of the national law incidental issue. ${ }^{87}$ In investment treaty arbitration the view on the normative role of the national law receives further strength due to the special nature of disputes more intervened in by national law. ${ }^{88}$

with the judgment rendered only on 13 September 1928. Of particular interest are also observations of Bin Cheng who suggests that one has to differentiate between the roles of the incidental issue. If the incidental issue is an essential condition in relation to the principal question then the decision of the court on it retains a binding force for that decision: '... when preliminary and incidental questions, which do not normally come within the competence of tribunal, fall within its competence because they are necessary for the determination of the principal question, decisions on these questions are not conclusive and binding unless they are an essential condition to the judgement on the principal suit. Such binding force is, however, limited to that judgment. The same question may be the subject of dispute between the same parties again either as an incidental question in another suit, or as a principal question before the competent tribunal. But whatever the outcome of these subsequent proceedings, the force of res judicata of the previous decisions can in no way be affected.' - Bin Cheng, General Principles of Law as Applied by International Courts and Tribunals (Stevens \& Sons 1953) 353.

87 See, for instance, Humphrey Waldock, 'General Course on Public International Law' (1962) 106 Recueil des Cours de l'Académie de Droit International 1, 124; Pierre-Marie Dupuy, 'International Law and Domestic (Municipal) Law' para.33, Max Planck Encyclopedia of Public International Law <https://opil.ouplaw.com/view/10.1093/law:epil/978019923169o/ law-978019923169o-e1056> last updated April 2011, last accessed 25June 2021; Ian Brownlie, Principles of Public International Law (7th edn, Oxford University Press 2008) para. 28-37; Andreas Zimmermann and Christian J Tams (eds), The Statute of International Court of Justice: A Commentary (1st edn Oxford University Press 20o6) 776-779; Sharif Bhuiyan, National Law in WTO Law: Effectiveness and Good Governance in the World Trading System (Cambridge University Press 2011) 208.

88 See, for instance, Hege Elisabeth Kjos, Applicable Law in Investor-State Arbitration: The Interplay Between National and International Law (Oxford University Press 2013) 253-258; Florian Grisel, 'The Sources of Foreign Investment Law' in Zachary Douglas and others (eds), The Foundations of International Investment Law: Bringing Theory into Practice (Oxford University Press 2014) 222-223; Jarrod Hepburn, Domestic Law in International Investment Arbitration (Oxford University Press 2017) 105; Ole Spiermann, 'Applicable Law' in Peter Muchlinski and others (eds), Oxford Handbook of International Investment Law (Oxford University Press 2008) 110-116; Jorge E Viñuales, 'Sources of International Investment Law: Conceptual Foundations of Unruly Practices' in Jean D'Aspremont and 


\subsubsection{Other Supporting Considerations (2): Reverse Conceptualisation- Public International Law Incidental Issues in Domestic Contexts}

Using the model of the concept of the incidental issue in private international law, this chapter proposes to conceptualise the incidental issue governed by national law in a public international law setting, or more precisely in investment treaty arbitration (referred to below as direct conceptualisation). In this context, the question may arise as to whether a reverse attempt to distinguish incidental issues in a domestic context that are governed directly by public international law instead of foreign national laws is appropriate (referred to below as reverse conceptualisation - see the table below). Reverse conceptualisation of the incidental issue is certainly not in itself of interest for this chapter, but because it opens up an important perspective on the usefulness of direct conceptualisation as a paradigm, it deserves the brief account below. Firstly, it might be worth looking at an attempt at reverse conceptualisation as an indicator of the concept's viability. Secondly, it might be interesting to explore the possible complexities of reverse conceptualisation in more general terms and whether the same or similar complexities appear in the case for direct conceptualisation.

A course exploring the public-private law divide given by Burkhard Hess for the Hague Academy of International Law may serve as an example of an attempt to introduce an issue governed by public international law as the incidental issue. Using the term 'public interests', but referring essentially to the

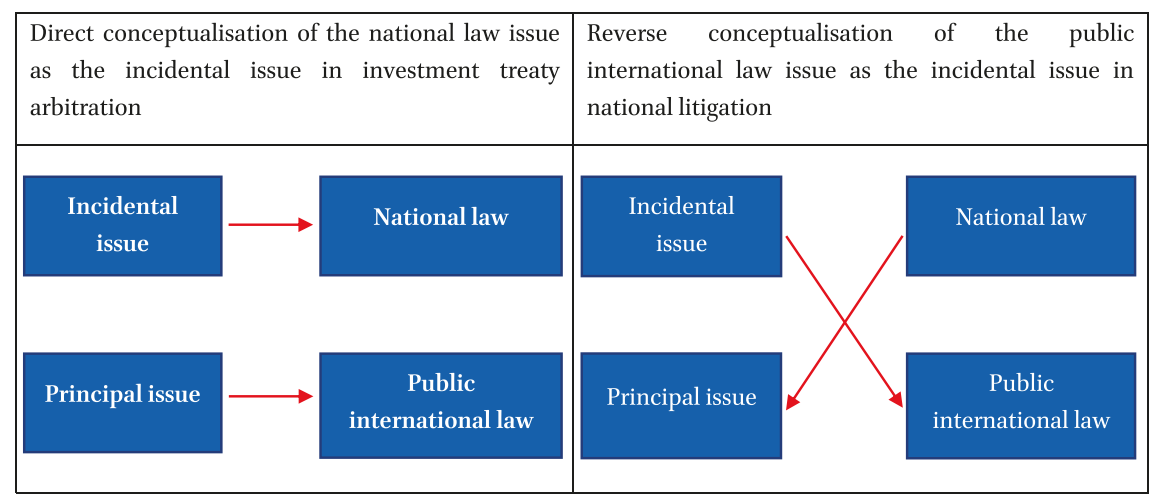

FIGURE 5 Direct and reverse conceptualisations

Samantha Besson (eds), The Oxford Handbook on the Sources of International Law (Oxford University Press 2017) 1074; Jan Ole Voss, The Impact of Investment Treaties on Contracts between Host States and Foreign Investors (Martinus Nijhoff Publishers 2011) 110-111. 
mandatory overriding provisions that domestic courts are required to take into account to decide on contract validity, Hess states that the origin of these 'public interests' may stem directly from public international law. Referring to the Nikiforidis case (ECJ case C-135/15) ${ }^{89}$ as an example, Hess suggests that 'public interests' deriving from public international law can be considered as the incidental issue in domestic proceedings. ${ }^{90}$

Of course, Hess's note on public international law as the origin of overriding mandatory provisions requires further explanation and exploration together with the suggested paradigm of the incidental issue. At the same time, there is nothing unusual as a matter of principle for international law to inform certain concepts, including the concept of public order. ${ }^{91}$ Extending the sources for overriding mandatory rules in domestic litigation beyond national law to public international law, Hess opens the door to public international law in domestic proceedings under the premises of the incidental issue, and thus overcomes challenges connected with the implementation and application of international law in domestic legal systems. Despite its novelty and a need for further thorough theorisation and (importantly enough) concrete examples, the attempt (to frame public international law as a core element of the incidental issue in domestic litigation) itself demonstrates the appeal of the theoretical frame that distinguishes between principal and incidental issues that are subject to different regulation to achieve uniformity in their treatment.

While it is true that domestic courts actively engage with public international law, and that this engagement is no less intensive than it is with foreign national laws, Hess identified a fundamental problem for reverse conceptualisation. Domestic courts regularly deal with numerous public international law issues ranging from human rights and environmental obligations to the law of the sea. These rules of international law frequently reflect international treaty obligations that states have undertaken to implement in their domestic legal systems ('inward looking' rules in the words of the International Law Association Preliminary Report) and are received and applied in many

89 Nikiforidis case (ECJ in the case C-135/15) <http://curia.europa.eu/juris/documents. jsf?num=C-135/15>, last accessed 25 June 2021.

90 Burkhard Hess, 'The Private-Public Divide in International Dispute Resolution' (2018) 388 Recueil des Cours de l'Académie de Droit International 49, 232-233.

91 On various sources for the Norwegian public order including public international law see Giuditta Cordero-Moss, 'Innholdet i ordre public-forbeholdet' in Giuditta CorderoMoss (ed), Norsk ordre public som skranke for partsautonomi i internasjonale kontrakter (Universitetsforlaget 2018) 163-186. 
different ways by domestic courts. ${ }^{92}$ However, whenever public international law is given effect, it is inevitably premised on national law. As a result, the regulatory distinctness of issues that are primarily governed by public international law is diluted, so in this sense public international law loses its 'foreign nature' in relation to national law and is assimilated by it before being applied. Precisely because the application of public international law in domestic contexts is rarely, if ever, completely disengaged from the domestic legal system, it is not surprising that reverse conceptualisation has not gained wide support. In contrast, this difficulty is not found in direct conceptualisation, as national law in public international law contexts retains its regulatory distinctiveness and exclusivity (at least with regard to subsidiary issues), and this, in contrast, serves as a basis for conceptualising the national law incidental issue in public international law contexts.

Reverse conceptualisation thus makes a two-fold contribution to this discussion. Firstly, an attempt at reverse conceptualisation demonstrates the legal paradigm's appeal and viability in addressing certain issues that are subject to different legal regimes separately, i.e. the concept of the incidental issue. Secondly, the obstacles to reversing conceptualisation in national law contexts, if contrasted with the lack of similar difficulties in public international law contexts (the differences between national law regulation and treaty regulation), assist in achieving a better understanding of existing predispositions for the direct conceptualisation of national law issues in public international law contexts, and adds to the argument for direct conceptualisation.

\subsubsection{Contribution of Conceptualising National Law Issues as Incidental Issues}

As the preceding discussion has demonstrated, investment treaty arbitration tribunals are exposed to the need to decide on legal issues that are governed by national laws. As these issues are not directly regulated by international investment agreements (IIAS) ${ }^{93}$ and may potentially be connected to various

92 The Preliminary Report of the International Law Association on Principles on the Engagement of Domestic Courts with International Law reveals, for instance, a wide range of ways in which domestic courts engage with international law. For more details see Antonios Tzanakopoulos, 'Preliminary Report: Principles of the Engagement of Domestic Courts with International Law (2011 - 2016)' <www.ila-hq.org/index.php/studygroups?study-groupsID=57 $>$ last accessed 25 June 2021.

93 While the interrelation between the public international law and national law as lex causae is an area for constant disagreement in investment treaty arbitration, what matters here is a sharp delineation between the principal and incidental issues that lies 
jurisdictions, they pose a question about the applicable national law. As a result, distinguishing between the principal and subsidiary issue in investment treaty arbitration is neither simply a reflection of the mechanical separation of the issues on the basis of their remoteness from the principal cause of action, nor of a different applicable regulation. The distinction contains more than that - a question about the relevant approaches or methodology for deciding on the law applicable to the issue that has to be resolved prior to any decision on a treaty cause of action. Investment treaty arbitration has therefore good ground for conceptualising the incidental issue in the same way as in private international law.

It is regrettable that there is not much done on conceptualisation of national law issues in investment treaty arbitration. In a similar way to the concept of the incidental issue in private international law, distinguishing between the principal and incidental issues in international investment law enables more structured reasoning and predictability. If we agree that certain issues are to be resolved $a b$ initio with due regard to governing national laws before treaty standards of investment protection are decided on, we do not risk mistreating or unduly assimilating the incidental issues that are governed by national laws. In this respect, decision-making algorithms based on premises that recognise incidental issues seem to be more coherent and stable in a conceptual sense. At the same time, the distinction does not erect a wall between international law's corrective role, which still has a place and for whose proper application national law's impact must first be considered. Nor does the distinction create any obstacles for investment treaty arbitration courts which are authorised to apply exclusively international law. The concept of the incidental issue frequently helps to remove unnecessary tension between international and national laws as lex causae introducing the relevance of national law consideration instead of the debatable applicability. While national law is applicable to the incidental issue, in the larger scale of the overall treaty dispute it may well be simply relevant. Treaty-based tribunals that are authorised by the NAFTA or the ЕСT, for instance, exclusively to apply international law to disputes may therefore retain their consistency and decide on incidental issues giving effect to national law applicable to them.

precisely on the border between international and national laws and reflects the nature of the questions involved. Whether national law applies to lex causae or not in investment treaty arbitration does not itself impact incidental issues which lie in full gravity of applicable national law. 
In the words of cognitive scientists, Mark Turner and Mathew McCubbins, concepts in law appear precisely as a result of the lack of mental capacity to deal with an infinity of various dependencies, which we tend to compress into 'tractable, much smaller, and more compact concepts that we can hold onto, manipulate, and develop. ${ }^{94} \mathrm{~A}$ legal concept's overall function is 'the compression of a messy reality into a simple logic that can be expanded again to guide decision-making in other messy environments.95 The concept of the incidental issue precisely compresses a messy reality of broad exposure to national law issues into an organised concept that requires a clear set of analytical efforts: identification, a question of the applicable national law and a decision under the applicable national law. It is better to face the problems of characterisation and conflict of laws and to look at how these questions are and should be resolved, instead of hiding and (mis)treating national law in isolation through idiosyncratic approaches or assimilation into other issues. Better-informed considerations can benefit both international and domestic systems, and can show that there is more unity than might be suggested. Once a decision on a national law issue is reached, it is easy to introduce it into the greater analytical effort of deciding on a treaty claim. The concept's appeal for investment treaty arbitration is further reconfirmed by the direct conceptualisation of the incidental national law issues of other public international courts and indirect conceptualisation of public international law issues in domestic settings.

While the boundaries identified in the nature of the issues and applicable regulations facilitate conceptualisation of the incidental issues, the issues themselves constitute important links between public and private international law. The fact that the very same issue pertaining to the legal status of companies, shareholder rights, property rights or contractual rights may appear as the incidental issue both in a pure private international law context and a public international law context demonstrates the complementary nature of both systems as units of a whole. The possibility of the same incidental issue appearing in a private international law context and a public international law context reinforces the value of conceptualisation in the increasingly connected world, ensuring intellectual discipline and the coherence of the internal (domestic) and international legal systems.

94 Mathew D McCubbins and Mark Turner, 'Concepts of Law' (2013) 86 Southern California Law Review 517, 568.

Ibid. 


\subsection{Contract Interpretation as the Incidental Issue in Investment Treaty Arbitration}

Having examined the requirements for the incidental issue in private international law and the reasons for conceptualising incidental issues in investment treaty arbitration, it is time to look at whether contract interpretation in investment treaty arbitration fits the incidental issue paradigm as developed in private international law and applied in public international law contexts. The section that follows explores in more detail the appropriateness of conceptualising contract interpretation as the incidental issue in investment treaty arbitration and this analytical approach's benefits for legal analysis.

To begin with, the discussion will concentrate on the fundamental parameters of the concept of the incidental issue in private international law that require an issue to be a separable legal question of subsidiary significance for the principal cause of action, with some dilemma regarding the applicable law.

\subsubsection{A Legal Issue}

Contract interpretation falls into the category of legal issue. Contract interpretation's legal nature, which has been already discussed in Chapter 2, is a fundamental element of the argument put forward here. Briefly, contract interpretation frequently entails assessing facts, and these facts often turn out to play a decisive role in understanding the content of contractual provisions. At the same time, reducing contract interpretation to fact-finding is an inappropriate oversimplification. Tribunals can ascertain the content of contractual provisions without resorting to fact assessment, as national law provides the necessary legal framework for this analysis. When fact assessment is needed for interpretative analysis, it is the law that defines its role and how it is carried out, either by allowing or excluding certain types of evidence or allocating evidence to specific stages in the process of ascertaining the content of contractual provisions, etc. Even jurisdictions that, due to the peculiarities of the judicial system's internal organisation mark contract interpretation as a factual matter for the purpose of limiting its review in the upper instances, nevertheless approach contract interpretation as a separate legal issue in legal doctrine and legislature. If carried out during interpretative analysis, fact-finding is therefore just one element of the process as a whole. In the law-fact dichotomy, ascertaining the content of contractual provisions is thus undoubtedly a legal issue and not a purely factual one. 


\subsubsection{A Separable Legal Issue}

Where the requirement to be a separable issue is concerned, contract interpretation, while compliant, brings a certain complexity and requires clarification. In the preceding section, it was not difficult to conceptualise contract formation, termination or validity as contract-related incidental issues in investment treaty arbitration because, in addition to other requirements, the issues were clearly distinguishable or separable. Instead of constituting a distinct ascertainable relationship or status, contract interpretation serves as the way to ascertain the content of contractual relationships, and in this sense, belongs to the field of legal interpretation, ${ }^{96}$ the category that depending on the object of interpretation also includes statutory interpretation, treaty interpretation, etc. No decisions can be made in relation to the contract-related incidental issue in investment treaty arbitration without a previous understanding of the contractual provisions. Accordingly, independent questions on contract interpretation are not usually raised unless there is a further question that is tied to more specific contract-related aspects, such as contract formation, contract termination, contract validity or contract rights and obligations. As a result, contract interpretation, whenever raised, is often confined to the shadows cast by other specific contract-centred legal issues, and this makes it more diffuse and 'less tangible', or separable.

Despite the diffuseness of its instrumental role in understanding other contract-related issues, contract interpretation is nevertheless traditionally treated as a separable legal issue in legal doctrine, national laws and transnational non-state instruments.

Legal doctrines in various jurisdictions traditionally define contract interpretation as an area of contract law that focuses on the approaches and

96 For locating contract interpretation among the various types of legal interpretation, see, for instance, Aharon Barak, Purposive Interpretation in Law (Princeton University Press 2005) 3-61; Jacques H Herbots, 'Interpretation of Contracts', Jan M Smits (ed), Elgar Encyclopedia of Comparative Law (Edward Elgar Publishing 2006) 325-348 and Stefan Vogenauer 'Statutory Interpretation' in Jan M Smits (ed), Elgar Encyclopedia of Comparative Law (Edward Elgar Publishing 2006) 677-689. Contract interpretation has two facets: one that is inward looking aimed at ascertaining the content of contractual provisions for decision-making and another that is outward looking and related to the persuasion reflected in the legal reasoning for an award. The inward looking ascertaining of the content of contractual provisions is not necessarily shown by lengthy reasoning and may be somewhat hidden (though still open to investigation by cognitive neurologists, etc.). Legal reasoning to varying extents represents the outward looking ascertainment of the content of contractual provisions. It is this aspect of contract interpretation that this book aims to investigate. See also Jaap Hage, 'Legal Reasoning' in Jan M Smits (ed), Elgar Encyclopedia of Comparative Law (Edward Elgar Publishing 2006) 407-422. 
methods used to ascertain the content of contractual provisions. The origin of treating contract interpretation separately has historical roots; in the European contract tradition those roots essentially come from Roman Law and have subsequently been shaped by other historical and socio-cultural peculiarities in each country ${ }^{97}$ Roman law paid particular attention to interpretative rules as essential elements of legal reasoning. As discussed in Chapter 2, certain jurisdictions choose not to have express specific provisions on contract interpretation which has not however impeded the development of contract interpretation in legal doctrine. On the contrary, contract interpretation in these jurisdictions receives elaboration through legal doctrine, judicial practice and other contract law rules.

With regard to national laws, again as discussed in Chapter 2, quite a few jurisdictions contain separate provisions on contract interpretation. Furthermore, private international laws in various jurisdictions list contract interpretation as one of the partial elements of a contractual relationship, along with other contract-related issues like contract formation, content of contractual rights and obligations, contract termination or contract invalidation..$^{98}$

The legal distinctness of contract interpretation as a legal issue is not only accepted by legal doctrine and in national laws, including national conflict of laws rules, but is also reflected by the final texts of various international documents aiming to harmonise international commercial law and private international law: the UPICC, the PECL and the DCFR, for instance, contain separate provisions on contract interpretation. Similarly, while defining the scope of applicable law for commercial contracts, the 2015 Principles on Choice of Law in International Commercial Contracts drafted by the Hague Conference on Private International Law expressly stipulate that contract interpretation falls into the sphere of the governing law. ${ }^{99}$

97 James Gordley, The Philosophical Origins of Modern Contract Doctrine (2nd edn Oxford University Press 2011) 30-230.

98 See, for example, Article 12 of Rome I, Article 33 of the Law of Ukraine on Private International Law, Article 1215 of the Civil Code of the Russian Federation, Article 1115 of the Civil Code of Kazakhstan, Article 35 of the Private International Law of Georgia, and Article 1612 of the Civil Code of Moldova.

99 Other issues defined by Article 9 of the Hague Conference on Private International Law which fall within the scope of applicable law are as follows: rights and obligations arising from contracts; performance and the consequences of non-performance, including assessment of damages; the various ways of extinguishing obligations, and prescription and limitation periods; validity and the consequences of invalidity, burden of proof and legal presumptions, and pre-contractual obligations. 
In other words, while contract interpretation is neither a completely autonomous legal issue, nor does it refer to status or legal relationships per se, as the most frequent types of incidental issues in private international law, it is nevertheless a distinguishable and separable legal issue.

\subsubsection{Playing a Subsidiary Role to the Principal Cause of Action}

Contract interpretation can certainly be said to play a subsidiary role in resolving the principal issue. Having defined its specific nature as somewhat diffuse if compared with other distinct contract-related issues, this in fact refers to contract interpretation's subsidiary role vis-à-vis the principal issue. As discussed in Chapters 1 and 4, contract interpretation is frequently needed before a decision on a treaty claim can be made. Tribunals may need to interpret contracts for contract-based treaty claims when a contract-related right directly triggers treaty protection under standards of investment protection such as FET, expropriation or umbrella clauses. Contract interpretation may be equally important because of another contract-related function in investment treaty arbitration that does not necessarily lead directly to a contract-centred treaty claim but may influence the overall decision on a treaty claim. It may therefore be necessary to interpret the contract to decide whether an investment has taken place or to define procedural aspects of the case or establish more peripheral aspects, etc. The ancillary role of contract interpretation is clearly shown by the multiple functions of contracts in investment treaty arbitration and the ultimate impossibility on many occasions to decide on a principal claim without first ascertaining the content of a contract.

This instrumental role of contract interpretation for understanding contractrelated issues is not an obstacle to conceptualising the incidental issue. On the contrary, the role of contract interpretation is directly captured by a specific sub-type of the incidental issue in private international law - the incidental issue of the second order. This refers to a subsidiary question that has to be dealt with before any other incidental issue of primary relevance for the principal issue can be resolved. Indeed, the content of relevant contractual provisions often has to be ascertained before a decision on termination, validity or any other contract-related incidental issue in investment treaty arbitration is reached. Contract interpretation's relevance for resolving these other incidental questions in investment treaty arbitration is thus a necessary precondition for conceptualising contract interpretation as the incidental question of the second order. Two subsections below illustrate type of occasions where contract interpretation shall fit well as the incidental issue of the second order in the structure of the tribunals decision-making. 


\subsubsection{The Case of Contract Termination}

The expropriation of contractual rights as a breach of international law was on the agenda for academics and in jurisprudence well before investment treaty arbitration emerged. With investment treaty arbitration, the expropriation of contractual rights as a breach of international investment law has received further development. While there may be numerous ways for a state to expropriate contractual rights, contract termination will be used here for illustration for simplicity and clarity. In this category of cases of expropriation of contractual rights via termination, the principal issue is whether the state has committed expropriation by terminating a contract and has thus violated international law. The answer to this public international law question depends on the responses to several other questions, including some that are contract-related and governed by national law. The question as to whether the state terminated the contract by exercising its contractual right must be among the national law questions to be asked, and tribunals have to ascertain the content of the contract provisions to answer this incidental question of the first order, and thus interpret the contract to some extent, where necessary.

Malicorp v. Egypt ${ }^{100}$ and Vigotop v. Hungary ${ }^{101}$ present two major patterns or tests for deciding on the expropriation of contractual rights via contract termination in investment treaty arbitration. As shown below, the tests differ as to when the question about contract termination should be asked, but contract termination plays a central role in both patterns, differences notwithstanding. The extent to which the tribunal engages with the contractual provisions varies from one case to another; as the parties did not disagree on the contract's precise content in Malicorp v. Egypt, its interpretation was less visible - mainly as part of the tribunal's analytical rational activity. By contrast, the parties in Vigotop v. Hungary disagreed vigorously over the content of the contract, calling expert witnesses and putting forward lengthy arguments on the contract's precise meaning to justify their positions. As a result, the interpretation of the contract became a hotly debated issue in the reasoning for the award and received extensive express coverage. ${ }^{102}$ What follows is a brief overview of how the contract termination question was dealt with as the contract-related incidental issue of the first order, and the role of contract interpretation was addressed as the incidental issue of the second order.

1 oo Malicorp Limitedv. The Arab Republic of Egypt, ICSID Case No. ARB/ o8/18.

101 Vigotop Limited v. Hungary, ICSID Case No. ARB B/11/22.

102 Vigotop Limited v. Hungary, ICSID Case No. ARB/11/22, Award dated 1 October 2014, para. 516-519, 535-538. 
In Malicorp v. Egypt, the tribunal dealt with the build-operate-transfer concession contract for the construction, management, operation and transfer of the Ras Sudr International Airport in Egypt agreed between a UK-registered company and the Government of the Arab Republic of Egypt. ${ }^{103}$ The concessionaire undertook to build and operate the airport on the land provided and subsequently to transfer it to the state. The general period of the contract was 41 years. The parties agreed that the contract was governed by Egyptian law and that CRCICA was the competent forum for contractual disputes arising under the concession. Less than a year after the contract was concluded, it was suddenly terminated by the Egyptian state, which referred, inter alia, to the failure on the part of the foreign investor, Malicorp, to open the company in Egypt and to fulfil other contractual undertakings. ${ }^{104}$ In its treaty-based claim before the ICSID, Malicorp claimed compensation for alleged treaty violations - the expropriation of contractual rights. ${ }^{105}$

By the time the treaty-based ICsID tribunal had started to deal with the issue, Malicorp had already obtained an award in a (parallel) commercial arbitration case before the CRCICA in relation to the contract's termination. The CRCICA tribunal found that the state had rightly terminated the contract, but because the termination had partly been due to a mistake on the state's part, Malicorp was nevertheless entitled to compensation of US\$14.7 million. ${ }^{106}$ While Malicorp tried to enforce the CRCICA award in France, ${ }^{107}$ the state initiated proceedings to set it aside in Egypt, which were still pending at the time of the ICSID claim.

The treaty-based tribunal approached the expropriation issue fairly straightforwardly. It stated that the solution essentially depended on a single issue regarding the validity of the termination of the contract. ${ }^{108}$ To reach a decision

103 Malicorp Limited v. The Arab Republic of Egypt, ICSID Case No. ARB/o8/18, Award dated 7 February 2011, para.93 (includes a summary of the content of the contract).

104 Ibid. para. 127 (cites the letter of rescission).

105 Since another claim on full protection and security had no other substantiation than the expropriation of contractual rights through premature termination, the tribunal dealt only with the expropriation claim.

106 Ibid. para. 58 .

107 Enforcement in France was refused at the time the ICSID case was being considered.

108 For completeness, it should be noted that a careful reading of the award shows that the test could have included another question on termination capacity that was redundant under the circumstances: 'The first question, therefore, is whether the Republic had the right to discharge itself from the Contract pursuant to the private law rules governing it .... If that is the case, it is unnecessary to examine whether the Respondent also took a measure under its public powers ("measures de puissance publique"), not as a party to the Contract but as a State, the effectiveness and conformity with the Agreement of which would have to be examined. Indeed, the rescission of the Contract would not leave any subsisting breach of the 
Contract interpretation

FIGURE 6 The Malicorp test

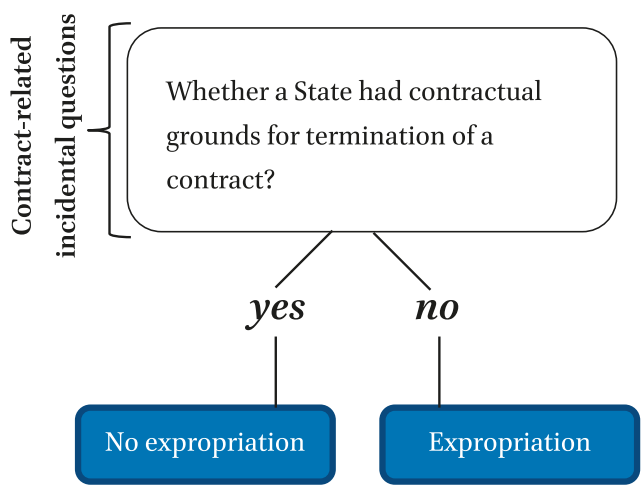

on the expropriation as a violation of an investment protection standard, the tribunal therefore had to decide whether the state had terminated the contract in compliance with its terms and the applicable national law. If it had, no issue of expropriation arose; if not - expropriation could have potentially taken place. In turn, the question on the correctness of the termination entailed investigating the obligations the parties had undertaken vis-à-vis each other under the contract, whether the parties had complied with their contractual obligations and whether the investor's failure to comply with contractual obligations was sufficient to justify its termination. ${ }^{109}$ Contract interpretation accordingly became part of the analysis aimed at establishing the content and significance of the undertakings agreed to by the parties under the contract. Figure 6 above shows the structure of the test.

Addressing the same contract provisions, the CRCICA award posed a serious question as to the effect of its reasoning and its finding in the treaty-based proceedings. The treaty-based tribunal decided to retain independence in its assessment of the contractual obligations. At the same time the reluctance to treat the CRCICA award as having res judicata effects did not prevent the treaty-based tribunal from selectively relying on some of the parts in which the CRCICA tribunal established the content of applicable Egyptian law. This approach enabled the tribunal to retain sufficient independence on the question of contract termination while selectively benefiting from the CRCICA award. In the annulment proceedings, the claimant attempted to argue that

umbrella clause nor, moreover, in the absence of a protected investment, of other clauses of the Agreement.' - see ibid. para. 126.

109 Another connected aspect of the case related to validity and mistake - see ibid. para. ${ }^{130-137 .}$ 
the treaty-based tribunal had failed to apply national law. The annulment committee found no violations amounting to a reason for setting the award aside in this form of ascertaining the content of national law.

In considering the weight of each contractual obligation, the treaty-based tribunal paid particular attention to the overall legal nature of the fact that the contract was concluded on вот terms. ${ }^{110}$ Build-operate-transfer schemes entail a serious input on the part of a foreign investor, starting as soon as the contract is concluded. The investor should have possessed sufficient financial, operational and technical capacity to begin building on the land provided by the state. From this perspective the tribunal understood that it was crucial for the foreign investor to provide due documentation of financial capacity, as well as readiness to carry out the project at its own cost and risk (Article 2.1), and, overall, demonstrate that there was a 'realistic prospect' of fulfilling the contract. ${ }^{111}$ The failure to set up the company in time to be able to fulfil contractual obligations (Article 3.1), which could potentially be less important in other contractual contexts, became crucial in the build-operate-transfer concession framework, and clearly showed unpreparedness on the part of the foreign investor in respect to this demanding contractual arrangement. Against this background the tribunal found that the state had terminated the concession contractually and rejected any attempts to justify or minimise the failures by referring to the failure on the part of the state to provide a site for the investor's use (Article 7.1). ${ }^{112}$ The findings also led the tribunal to conclude that the termination of the contract did not amount to expropriation because 'termination justified in fact and in law, could not be interpreted as an expropriatory measure'.113

In Vigotop v. Hungary, the tribunal dealt with a concession agreement for setting up and running one of the largest casinos in Europe on Hungarian territory. The concession agreement was concluded for 20 years with the option of a 10-year extension. ${ }^{114}$ The state terminated the contract after just over a year, alleging two major failures on the part of the foreign investor to fulfil the contract. One failure related to the obligation to possess the required property for

\footnotetext{
110 Ibid. para. 132.

111 Ibid. para. 141.

112 Ibid. para. 140. The tribunal recognised that the state had indeed failed to provide a plot of land. At the same time, the tribunal explained that the investor's argument could only have succeeded under different contractual arrangements if 'that land could have served as security for the company's founders to obtain loans for funds they did not have'.

113 Ibid. para. 143.

114 Vigotop Limited v. Hungary, ICSID Case No. ARB/11/22, Award dated 1 October 2014, para. $142-153$.
} 
the running of a casino (clause 9.3 of the contract) ${ }^{115}$ and another to the obligation to provide payment security (clause 12.1 of the contract)..$^{116}$ The parties disagreed on the precise content of these contractual obligations and these became the object of heated debate in the course of the proceedings, which involved expert witnesses on both sides.

In contrast to the essentially one-step analysis in Malicorp v. Egypt, the tribunal in Vigotop $v$. Hungary offered a more nuanced algorithm to deal with the question of the expropriation of contractual rights. As can be seen from Figure 7 on the next page, the test consists of three major steps. The question as to whether the contract was terminated in accordance with the terms appears as a single step in the analysis, and then only if the first question as to whether the state acted in its sovereign capacity when terminating the contract receives an affirmative answer (Question 1 in Figure 7). If the state acted in its sovereign capacity, the next question is whether there were contractual grounds for terminating the contract (Question 2 in Figure 7). If the termination is contractual, there is no case for expropriation. If the termination is not contractual, the analysis moves on to the reasons for the termination and a possible finding of expropriation (Question 3 in Figure 7 ).

Despite occupying second place in the algorithm [for the Vigotop test], the question on the contractual grounds for contract termination nevertheless retains similar significance to the question in the Malicorp test. To find expropriation, it is not sufficient for the state to exercise its public powers. There should be no contractual grounds that would justify termination; if, in addition to its public functions, the state terminates a contract because the terms allow it to do so, no expropriation can be found. The question on contract termination in turn entails the need to ascertain the content of the contract provisions, i.e. contract interpretation. Depending on the provisions' clarity, the parties' arguments, and the circumstances of the particular case, the contract interpretation may be more detailed or less, but in any event it is unavoidable

115 Ibid. para.147. Clause 9.3 of the Concession Contract says: 'Starting from January 1, 2011 up to expiry of the concession period, the Concession Company shall continuously hold the legitimate right to possession of the real properties for establishment of the Casino, to performance of the activities subject to Concession and the Supplementary Activities and/or the portion of those real properties suitable for performance of the activity subject to Concession and the Supplementary Activities and the right to encroachment of the necessary superstructures within the settlement where the activity subject to concession is exercised.'

116 Ibid. para.148. Clause 12.1 of the Concession Contract says: 'As a security for any of its payment obligations arising from this Contract, the Concession Receiver shall ensure from January 1, 2010 for the full concession period without interruption a bank guarantee, security deposit or cash surety.' 


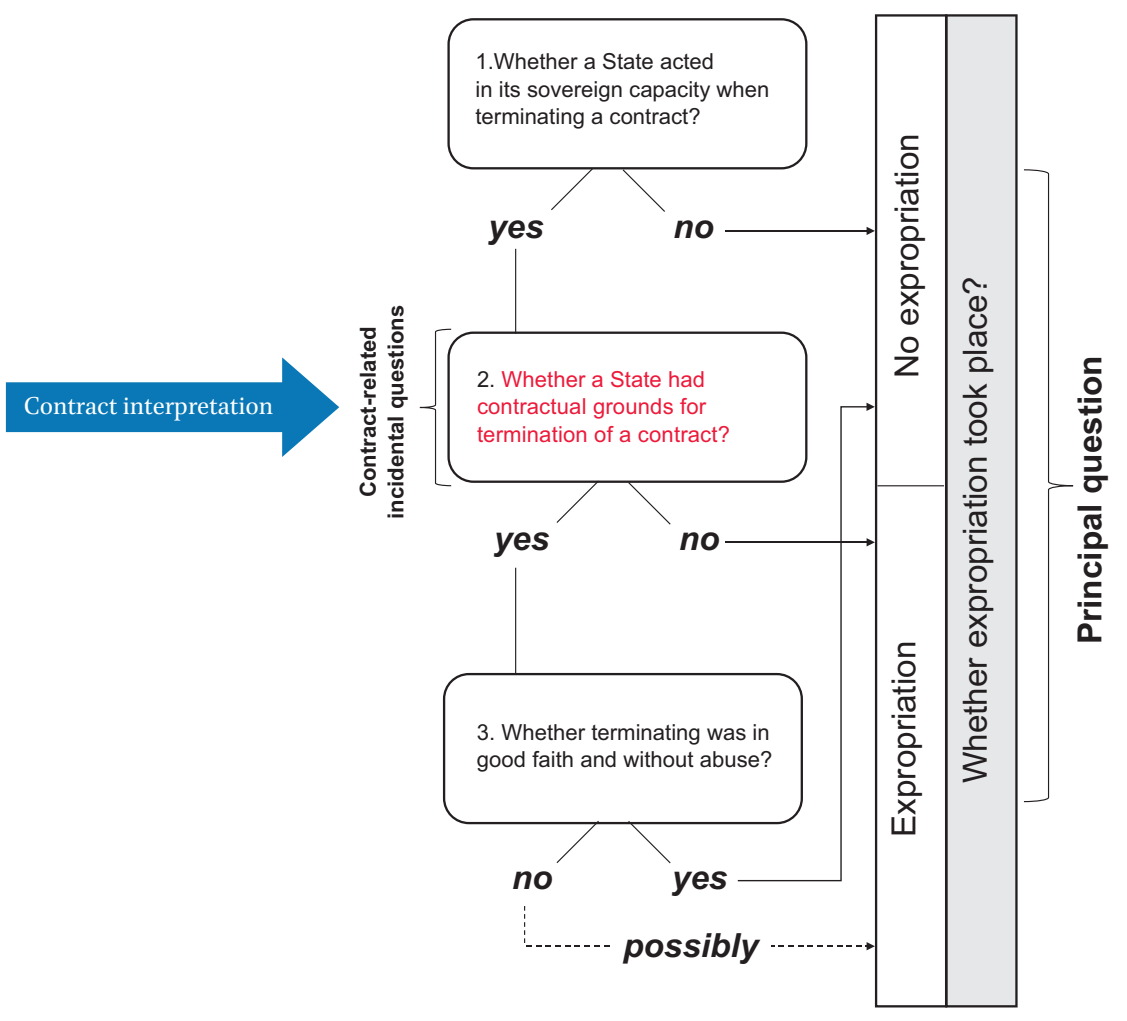

FIGURE 7 The Vigotop test

for deciding on the contractual validity of termination and ultimately on the expropriation of contractual rights.

Due to the acute disagreement between the parties on the precise content of the contractual provisions, it is no surprise that the tribunal in Vigotop v. Hungary engaged in interpreting the contract more intensively than the tribunal in Malicorp v. Egypt. With regard to the foreign investor's undertakings to secure property for the casino, the tribunal accepted the respondent's interpretation of the foreign investor's duty to secure property for the project and found no justification for Vigotop's failure in this regard. ${ }^{117}$ Where payment security was concerned, the tribunal also endorsed the respondent's interpretation of the relevant contract provision and found that the foreign investor

117 The fact that the land swap transaction by which an investor had previously obtained rights over a (valuable lakeside) property was cancelled led to the investor's failure to comply with the contract deadline for securing an alternative site; this served as relevant background to the tribunal's findings. The matter relating to the land swap cancellation 
had breached the contract in this aspect by failing to provide it. If the failure to provide security did not in itself amount to sufficient grounds for contract termination, in the tribunal's reading of the termination provision, the failure to secure possession of property was sufficient grounds for termination. This understanding of the contractual obligations led the tribunal to conclude that the termination was contractual and accordingly that no expropriation took place in relation to the concession agreement.

\subsubsection{The Case of Implied Terms}

Another example where contract interpretation plays a subsidiary role to the principal issue relates to analysis in disputes premised on the necessity to verify if there are implied terms in a contract. The question of implied terms typically appears in the context of discussion of FET or in umbrella clauses, or both. Tribunals face the question of whether an investor under a contract acquires certain legitimate expectations that are protectable in investment treaty arbitration. ${ }^{118}$ While some tribunals attempt to analytically divorce the establishment of legitimate expectations on the basis of contracts from contract interpretation, ${ }^{119}$ little doubt remains nowadays that legitimate expectations drawn on the basis of contractual undertakings necessitate the construction of the contractual undertakings of the parties in the first place. ${ }^{120}$ It is not uncommon for tribunals, instead of using national law to substantiate their reasoning by pointing to a contract as a whole, to analyse the economic underpinning and/or reasonableness of the alleged undertaking under the circumstances, as well as other contextual evidence - negotiations, exchanges, other contract-related documents, etc.

went through all the instances in the Hungarian court system, with Hungary's Supreme Court ultimately deciding that the land swap was null and void.

118 Mamidoil Jetoil Greek Petroleum Products Societe Anonyme S.A. v. Republic of Albania, ICSID Case No. ARB/11/24 Award dated 30 March 2015, para. 648; Georg Gavrilovic and Gavrilovic d.o.o.v. Republic of Croatia, ICSID Case No. ARB/12/39, Award dated 25July 2018, para.440-457, 946; AES Corporation and Tau Power B.V. v. Republic of Kazakhstan, ICSID Case No. ARB/10/16, Award dated 1 November 2013, para. 297, 336, 374.

119 See for instance, AES Corporation and Tau Power B.V.v. Republic of Kazakhstan, ICSID Case No. ARB $/ 10 / 16$, Award dated 1 November 2013, para. 297.

120 James Crawford, 'Treaty and Contract in Investment Treaty Arbitration' (2008) 24 (3) Arbitration International 351, 374; Georg Gavrilovic and Gavrilovic d.o.o. v. Republic of Croatia, ICSID Case No. ARB/12/39, Award dated 25July 2018, para.965, where the tribunal concluded: '... there can be no legitimate expectation in respect to the Properties to which the Claimants have no property or contractual right.' [emphasis added]. 
Save on some occasions, ${ }^{121}$ tribunals predominantly keep the contracts to their express terms.

For instance, in the case of the relocation of the investment in Mamidoil Jetoil Greek Petroleum Products Societe S.A. v. Republic of Albania, ${ }^{122}$ the tribunal refused to imply an undertaking on the use of port facilities for a longterm lease contract concluded 20 years beforehand. The claimant substantiated its position by the economic rationale that the whole idea of having a lease is to ensure stability for its investment, whereas the decision to build and operate a tank farm in the port was all about being able to use the port facilities. ${ }^{123}$ The tribunal found more persuasive a mismatch between the significance of the alleged undertaking for the whole transaction and a failure to address it in the exchanges and documents surrounding the deal, such as in its business plan. ${ }^{124}$ Furthermore, the tribunal took into consideration the fact that the nominal price agreed in the lease agreement was too small to cover the undertaking that the claimant attempted to imply. ${ }^{125}$ A refusal to imply a term appeared to be an important part of the decision denying the claim of violation of FET. ${ }^{126}$ While factual considerations of the surrounding context and economic underpinning of the transaction in question are relevant, it is national law that gives shape to the analysis. At no stage, however, had the tribunal considered the law governing the lease agreement (it is unclear from the analysis which law was applicable to the lease agreement though the tribunal

121 While it may be open to debate, one may consider the tribunal's statement in relation to the choice of applicable law for the settlement agreement concluded between Joseph Charles Lemire and Ukraine as being a finding on implied terms: 'When negotiating the Settlement Agreement, the parties evidently gave thought to the issue of applicable law, and were apparently unable to reach an agreement to apply either Ukrainian or US law. In this situation, what the parties did was to incorporate extensive parts of the UNIDROIT Principles into their agreement, and to include a clause which authorises the Tribunal either to select a municipal legal system, or to apply the rules of law the Tribunal considers appropriate. Given the parties' implied negative choice of any municipal legal system, the Tribunal finds that the most appropriate decision is to submit the Settlement Agreement to the rules of international law, and within these, to have particular regard to the UNIDROIT Principles.' - Joseph Charles Lemire v. Ukraine, ICSID Case No. ARB/ o6/18 (Lemire II) Decision on Jurisdiction and Liability dated 14 January 2010, para. 111.

122 Mamidoil Jetoil Greek Petroleum Products Societe S.A. v. Republic of Albania ICsID Case No.ARB $/ 11 / 24$.

123 Mamidoil Jetoil Greek Petroleum Products Societe S.A. v. Republic of Albania, ICsid Case No.ARB/11/24, Award dated 3o March 2015, para. 647 .

124 Ibid. para. 648 .

125 Ibid.

126 Ibid. para. 663 . 
applied Albanian law ${ }^{127}$ to decide on other issues, in particular regarding the legality of the investment). The decision was adopted with a dissenting voice. The dissenting arbitrator disagreed with the majority, arguing that they had ignored 'the factual record, including evidence that the parties understood that the ability to discharge tankers at Claimant's facility was essential to the viability of Claimant's investment.' ${ }^{128}$

Similarly, when dealing with implications of terms through preambles and best efforts clauses applicable national law shall be considered. Depending on their content, preambles (or recitals) may serve as an important tool for contract interpretation. ${ }^{129}$ Their interpretative capacity lies in their individualised character. Unlike boilerplate clauses, preambles are not standardised..$^{130}$ Parties negotiate them individually to reflect a common intent and considerations that have led them to conclude a contract. ${ }^{131}$ Preambles may contain

127 Under the Albanian Civil Code, interpretation is to be exercised with full effect given to the parties' 'common and real' intent without being limited to the literal meaning of the words and evaluating with due regard given to the parties' conduct (Article 681). As a rule of last resort Article $68 \mathrm{~g}$ of the Civil Code of Albania empowers an interpreter to adopt an interpretation for 'non-gratuitous' contracts which would equitably reconcile the interests of the parties.

128 Mamidoil Jetoil Greek Petroleum Products Societe S.A. v. Republic of Albania, ICSID Case No.ARB/11/24, Dissenting opinion of Steven A Hammond dated 20 March 2015, para.21.

129 In addition to interpretation, Marcel Fontaine and Filip De Ly name eight other legal effects of preambles which are not necessarily entirely independent from interpretation - see Marcel Fontaine and Filip De Ly, Drafting International Contracts (Martinus Nijhoff Publishers 2009) 87-100.

130 It may be illustrative that standard contracts prepared by various associations and organisations do not have preambles. This is the case, for instance, with ICC model contracts for sale, agency, distributorship and others - see Fabio Bortolotti, Drafting and Negotiating International Commercial Contracts (3rd edn, ICC 2017) 151-254. This is also the case with numerous GAFTA and FOSFA standard contracts on the sale of soft commodities, available at <https://www.gafta.com/All-Contracts> and at <https://www.fosfa.org/contracts/>, last accessed 27 August 2020. As an exception to the general trend, some FIDIC contracts have introduced preambles which essentially move the content of certain annexes into the text of the principal contract. For instance, the 1987 edition of the Yellow Book, on mechanical and electric work, introduced a preamble to insert information within the principal text of a contract instead of an Appendix to Tender - see Peter L Booen, 'The Four FIDIC 1999 Contract Condition: Their Principles, Scope and Details' available at $<$ http://fidic.org/node/6159>, last accessed on 27 August 2020.

131 A limitation of considering the parties' intent beyond its textual expression in a common law tradition, particularly under English law, may be viewed as a historic and most probably the primary reason for the emergence of voluminous preambles in contractual practice. See, for instance, an article from 1935 in which recitals are explained as follows: [ $[T]$ he introduction of contract recitals may have been induced by certain characteristics of early English law. Thus, the common law prohibition against the testimony of interested parties 
various narratives of factual and legal contexts preceding and surrounding the deal. ${ }^{132}$ Definitions of terms are frequently also located in preambles. Put figuratively, preambles frequently store important contractual DNA that might become critical to understanding the content of contractual provisions. The interpretative role of preambles, however, shall not be overstated in isolation from applicable legal frameworks. As with boilerplate clauses, ${ }^{133}$ the precise operation of preambles depends not only on their wordings and the interpretative task they help to solve, but also and primarily on the applicable national law governing a contract. The differences in approaching preambles under national law mimic the fundamental distinctions across jurisdictions in contract interpretation summarised in Chapter 2 as a tension between predictability and fairness which national laws solve somewhat differently. As a consequence of this tension and other distinctions, national laws may accord a greater or lesser role to the interpretative function of preambles. ${ }^{134}$ They may also set certain prerequisites for the preambles to control and qualify contractual provisions in the operative part of a contract. ${ }^{135}$ National laws may differ

may have provided a strong incentive for this admissible registering of mutual intent.' - 'The Effect of Recitals in Contracts' (1935) 35 (4) Columbia Law Review 565, 568.

132 It is interesting to note that some authors see preambles not as an introduction to the study of more context, but as indirect textualist clauses that are aimed at limiting contextual evidence by the precise content that became an integral part of it - see Uri Benoliel, 'The Interpretation of Commercial Contracts: An Empirical Study' (2017) 69 (2) Alabama Law Review 469, 484-485.

133 As discussed in Chapter 2, one of the most revealing visualisations of differences in contract interpretation across jurisdictions comes via the examples of commonly used contractual provisions - boilerplate clauses. Comparative studies demonstrate that entire agreement (merger) clauses, no oral amendment clauses, severability clauses and some other standard clauses may be understood differently and produce a different legal effect depending on the governing law. See, for instance, Giuditta Cordero-Moss (ed), Boilerplate Clauses, International Commercial Contracts and the Applicable Law (Cambridge University Press 2011).

134 The uncitral Guide on Construction of Industrial Works, cited by Marcel Fontaine and Filip De Ly to support a proposition on a different role being attributed to preambles under national laws, expressly specifies that: 'The extent to which recitals are used in the interpretation of a contract varies under different legal systems, and their impact on interpretation may be uncertain. Accordingly, if the contents of recitals are intended to be significant in the interpretation or implementation of the contract, it may be preferable to include those contents in contract provisions.' - The UNCITRAL Guide on Construction of Industrial Works 1988, available at <https://www.uncitral.org/pdf/english/texts/ procurem/construction/Legal_Guide_e.pdf $>$, last accessed 27 August 2020. See also Edward Allan Farnsworth, 'The Interpretation of International Contracts and the Use of Preambles' (2002) 3/4 International Business Law Journal 271.

135 For instance, under English law, the use of preambles to control, cut down or qualify contractual provisions may only be possible in cases when the respective provisions are 
in accepting preambles as an independent source for substantive contractual undertakings. ${ }^{136}$

Likewise, undertakings of due care and diligence in the operative part of a contract cannot be understood in isolation from applicable national law. Save for potential exceptions, these obligations do not result from the parties' failure to express themselves more clearly. The provisions are rather a consequence of a dilemma faced by the parties between an impossibility, for various reasons, to agree on an obligation in its absolute terms, on the one hand, and a desire to attribute to an obligation a certain binding force to facilitate its future fulfilment, on the other hand. Absolute obligations, or obligations of results, ${ }^{137}$ are not as a rule framed as a best efforts undertaking. One can hardly imagine an obligation to pay the price or deliver the goods as a best efforts undertaking, but one can easily accept an obligation of best effort in situations where an undertaking is conditioned by external forces or where an undertaking is dependent upon the performance of the other party. Unsurprisingly, undertakings of due care and diligence are frequently discussed in the literature, and in practice in the context of what would be a reasonable effort for a particular industry or field, for instance, in research, distributorship, joint venture, etc. While the industry or field is essential to understanding the nature of an

ambiguous - see Kim Lewison, The Interpretation of Contracts (5th edn, Sweet \& Maxwell 2011) 525-530. Under French law, there is arguably more possibility for the use of recitals in interpretation of the operative part regardless of whether the clauses are ambiguous, because Article 1188 of the Civil Code of France provides that a contract is to be interpreted according to the common intention of the parties rather than stopping at the literal meaning of its terms. See also, Marcel Fontaine and Filip De Ly, Drafting International Contracts (Martinus Nijhoff Publishers 20o9) 89.

${ }_{13} 6$ For instance, Lewison, while giving examples when courts applying English contract law treated undertakings in recitals as binding obligations, observed that the courts would be cautious in doing so and even reluctant if the contract in the operative part already has obligations on the same subject - Kim Lewison, The Interpretation of Contracts ( $5^{\text {th }}$ edn, Sweet \& Maxwell 2011) 531-533. In the same vein, Marcel Fontaine and Filip De Ly recommend that: [ $t]$ he appropriate place for operative provisions is the body of the contract and it is suggested that such provisions should not be contained in recitals.' - Marcel Fontaine and Filip De Ly, Drafting International Contracts (Martinus Nijhoff Publishers 2009) 102.

137 For instance, 'obligations de moyens' and 'obligations de résultat' in French contract doctrine and jurisprudence on the basis of the old Article 1147 in the Civil Code of France, prior to the 2016 revision (currently in Article 1231-1 of the revised Civil Code of France) also informed the 'obligation of best efforts' and 'obligation to achieve a specific result' in Article 5.1.4 of the UPICC - see Stefan Vogenauer and Jan Kleinheisterkamp (eds), Commentary on the UNIDROIT Principles of International Commercial Contracts (PICC) (Oxford University Press 2009) 548-552. 
undertaking and the degree of efforts in the best efforts undertaking, ${ }^{138}$ they are not self-sufficient. Because national laws differ in recognising good faith as a duty of the parties in contract performance, their role should not be ignored. Due care, diligence, best efforts undertaking, best endeavours, commercially reasonable efforts, reasonable care, and good faith efforts, are all variations, and are not necessarily identical, ${ }^{139}$ of a behavioural standard essentially based on the principle of good faith and fair dealing in contract performance. That some laws contain an implied duty of good faith for contracting parties and others ${ }^{140}$ may become an important consideration for understanding the precise content of the contractual provision referencing one of these variations of due care undertaking.

In the same vein, when both types of provisions - preambles and undertakings on best efforts - are invoked simultaneously to solve an interpretative question, their assessment cannot be exercised in entire disengagement from applicable national law. While no doubt dependent on the wording, principles and concepts of the underlying contract law would nevertheless inform understanding of these provisions and of the contract overall. Apparently, the similar wording of preambles and best efforts undertakings may receive different legal effects depending on the applicable national law. ${ }^{141}$

Eureko B.V.v. Poland ${ }^{142}$ illustrates a tribunal's failure to consider the applicable national law in the interpretation of a preamble and an obligation of due

138 In the context of the role of certain industries for understanding the parties' contractual undertakings, it is interesting to observe a recent view of some scholars on the global fragmentation in transnational contract laws as a phenomenon - see Joshua Karton, 'Sectoral Fragmentation in Transnational Contract Law' (2018) 21 (1) University of Pennsylvania Journal of Business Law 142.

139 Definitions of the terms may vary - for a comprehensive account, see Marcel Fontaine and Filip De Ly, Drafting International Contracts (Martinus Nijhoff Publishers 2009) 187230 and Christine Chappuis, 'Les clauses de best efforts, reasonable care, due diligence et les règles de l'art dans les contrats internationaux' (2002) 3/4 Revue de Droit des Affaires Internationales 281 .

140 See, for instance, Giuditta Cordero-Moss, 'Lectures on Comparative Law of Contracts' (2004) 166 Publications Series of the Department of Private Law, 124-136, University of Oslo. See also, Jeannie Marie Paterson, 'Good Faith Duties in Contract Performance' (2014) 14 (2) Oxford University Commonwealth Law Journal 283, 283-309 and Martijn W Hesselink, 'The Concept of Good Faith' in Arthur Hartkamp and others (eds), Towards a European Civil Code (3rd fully rev. and exp. edn, Kluwer Law International 2004), 630-634.

141 See Marcel Fontaine and Filip De Ly, Drafting International Contracts (Martinus Nijhoff Publishers 2009) 207-222.

142 Eureko B.V. v. Republic of Poland, Ad Hoc Arbitration under the Agreement between the Kingdom of the Netherlands and the Republic of Poland on Encouragement and Reciprocal Protection of Investment, Partial Award dated 19 August 2005. 
care and diligence. A dispute arose out of the privatisation of a large, stateowned insurance company, Powszechny Zaklad Ubezpieczen S.A. ("PZU"), in Poland. To resolve the dispute, the tribunal had to interpret precisely what the parties had undertaken in relation to the IPO. The tribunal had to decide, in particular, whether Poland unequivocally promised to sell shares to Eureko B.V. and whether, as a result, Eureko B.V. had acquired enforceable rights in respect of shares and subsequently in relation to corporate governance in this regard. Interpreting the SPA, the majority of the tribunal concluded that the initially signed SPA did not reflect a definite undertaking on the part of Poland in relation to the IPO, but just an intention. Reverting however to the First Addendum, the majority found that the text of the preamble and substantive provisions 'demonstrate clearly that the statement of intent which had been agreed by the parties in the SPA had now crystallized and become a firm commitment of the State Treasury'.143

The text of the preamble to the First Addendum became instrumental to the interpretation and was relied upon to find an obligation 'to exercise due care and diligence in order to have the IPO concluded before December 31, 2001' in the operative part of the First Addendum, a firm undertaking equivalent to the acquired right of an investor. This observation led the majority to find that Eureko B.V. possessed an investment that, when assessed together with the shares it had purchased, constituted a controlling share in PZU. Failing to carry out the IPO, together with other factual circumstances, was ultimately deemed Poland's failure to grant fair and equitable treatment, and a violation of an umbrella clause in relation to contractual rights to the IPO that formed the basis of the legitimate expectations of the foreign investor. Nowhere in the reasoning did the majority consider Polish law regulations pertaining to contract interpretation in general, or in relation to contractual preambles and due care and diligence undertakings. ${ }^{144}$

The exercised interpretation of the majority raised a dissenting opinion $^{145}$ of the only arbitrator on the panel qualified in Polish law - Jerzy

\footnotetext{
143 Ibid. para. 152.

144 The parties to the SPA and the First Addendum to the SPA made Polish law expressly applicable (paragraph 6 of the SPA and Article 6.1 of the First Addendum to the SPA).

145 Dissenting opinions are rather common in investment treaty arbitration. Some scholars question their significance, noting, on the basis of empirically studied dissenting opinions, that if an arbitrator should dissent on the basis of principles only, 'few ... seem warranted' - Albert van den Berg, 'Dissenting Opinions by Party-Appointed Arbitrators in Investment Arbitration' in Mahnoush H Arsanjani and others (eds), Looking to the Future: Essays on International Law in Honor of W. Michael Reisman (Martinus Nijhoff Publishers 2010) 842. For a view supporting dissenting opinions in investment treaty arbitration, see, for instance, Pedro J Martinez-Fraga and Harout Jack Samra, 'A Defense
} 
Rajski. ${ }^{146}$ The dissenter disagreed with the majority, who characterised the undertaking 'of due care and diligence' on the IPO as a firm undertaking. He pointed to another obligation of the parties in the First Addendum by which they were to undertake to adopt a new schedule if the IPO was not concluded before 31 December 2001.

Furthermore, Rajski specified the limited role of preambles for contract interpretation under Polish law:

In Polish contract law and practice (as in the law and practice of many other countries) it is beyond any doubt that the parties to a contract do not create contractual rules in its preamble (unless otherwise expressly stipulated by the parties). The preamble to a contract simply serves other purposes (to declare the parties intentions and expectations, to describe their objectives, etc. $)^{147}$

In his view, this failure led to the undue stretching of undertakings of 'due care and diligence' in the operative part of the First Addendum by inferring, on the basis of its preamble, a binding commitment. The dissenter became rather categorical in characterising the interpretation exercised by the majority as: 'bordering on manipulation, incompatible with basic rules applicable under Polish law. ${ }^{148}$ According to Rajski, more was required under Polish law for the preambles to become a source of binding undertaking in the presence of an express undertaking 'of due care and diligence' that the parties had agreed to.

of Dissents in Investment Arbitration' (2012) 43 (3) University of Miami Inter-American Law Review 445, 445-477. As will be demonstrated below, the dissenting opinion of Jerzy Rajski was warranted at least in what relates to the interpretation of the SPA.

146 Professor Jerzy Rajski was a member of the commission entrusted to develop the Civil Code of Poland and participated in the work on the UPICC from 1983-1989 as well as in the Study Group on a European Civil Code. He has authored a number of publications in Polish contract law, including for instance, Jerzy Rajski, 'European Initiatives and Reform of Civil Law in Poland' (2008) 14 Juridica International 151; Jerzy Rajski, 'On the Need for A Progressive Harmonisation of Private Law in The European Union: The Role of Legal Science and Education' (2006) 11 Juridica International 20. A list of publications and a biographic note for Jerzy Rajski is available here - Beate Gessel-Kalinowska vel Kalisz (ed), The Challenges and the Future of Commercial and Investment Arbitration (Lewiatan Court of Arbitration 2015) 7-29.

147 Eureko B.V. v. Republic of Poland, Ad Hoc Arbitration under the Agreement between the Kingdom of the Netherlands and the Republic of Poland on Encouragement and Reciprocal Protection of Investment, Partial Award dated 19 August 2005, Dissenting opinion, para 5 .

148 Ibid. 
That the tribunal has not cited an entire text of the SPA and the First Addendum in the Partial award makes it difficult to confront the analysis of the majority with a more reliable analysis, but even the cited provisions in the award are sufficient to question the reasoning of the majority. Reading Article 65 of the Polish Civil Code, one can no doubt see that the common intention of the parties and the contract purpose take priority over the literal meaning of the contractual wording. ${ }^{149}$ This means that, in an abstract way, one may accept that preambles, as repositories of the parties' intent and purpose, can assist in a teleological interpretation and that such interpretation should be sanctioned under Polish law. When one attempts to construe the concrete text of the SPA and the First Addendum, one becomes puzzled as to how an expression of intent in the preamble of the First Addendum could have transformed an undertaking that parties expressly framed as being of 'due care and diligence' in the operative part into a firm obligation, and de facto into an obligation of result. If one were to take the reasoning of the majority to its extreme, one could conclude that any undertaking on due care and diligence in the operative part can be (relatively easily) transformed into a firm obligation if the parties in the preamble spell their intent to achieve what, in the operative part, had carefully remained an obligation of due care and diligence. Furthermore, the exercised interpretation does not fit well with another express undertaking under the First Addendum, by which the parties agreed that in case no IPO is possible within the stipulated timeframe, they would 'unconditionally undertake to adopt a new schedule' but failed to specify the precise framing for agreeing this new schedule and for conducting the IPO. One may accordingly argue that should the parties have wanted the IPO unconditionally to have taken place within the set deadline, they could easily have spelt out their undertaking in more absolute terms. Inspired by the method of diagramming interpretation, ${ }^{150}$ Figure 8 visualises the tribunal's reasoning.

Even though the case was ultimately settled, it would not be unreasonable to conclude that the dissenting arbitrator was right on at least two accounts:

(1) the majority should have ascertained the approach to contract interpretation under Polish law prior to engaging in ascertaining the content of the SPA;

149 On the so-called 'combined' objective-subjective Polish method see, for instance, Zygmunt Tobor and Tomasz Pietrzykowski, 'Does Theory of Contractual Interpretation Rest on a Mistake' in Bettina Heiderhoff and Grzegorz Zmij (eds), Interpretation in Polish, German and European Private Law (Verlag Dr Otto Schmidt 2011) 16.

150 James Durling, 'Diagramming Interpretation' (2018) 35 (1) Yale Journal on Regulation 325. 

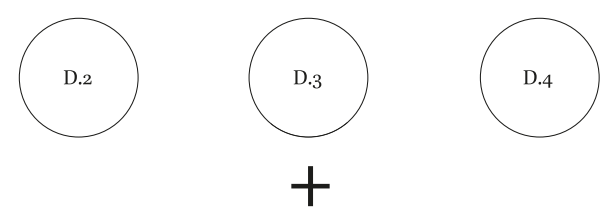

5.1. The Parties and their duly elected representatives in the respective management boards and supervisory boards of PZU and its subsidiaries, shall exercise due care and diligence in order to have the IPO concluded before December 31, 2001.

5.3 The Parties agree that in the case the IPO is not completed by the end of 2007 , the rules and terms established under 5.1 and 5.2 will apply to the IPO at a later stage. The Parties unconditionally undertake to adopt a new schedule for the IPO in such a case.

5.4 The Parties unconditionally undertake that following the IPO the Parties shall make their utmost efforts to agree the schedule for the public offering of any remaining shares held by the State Treasury.

5.4 (sic) The State Treasury undertakes to assist Eureko in their efforts to obtain the needed authorization for the performance of this Addendum and the permit of the Minister of Finance to allow Eureko to become a majority - $51 \%$ shareholder of Pzu.
Preamble,

by concluding this Addendum

The Parties intend

152. However, the preamble and substantive provisions of the First Addendum demonstrate clearly that the statement of intent which had been agreed by the parties in the SPA had now crystallized and become a firm commitment of the State Treasury.

157. Consequently, the Tribunal finds that, under the First Addendum, the Republic of Poland contracted obligations and Eureko acquired rights derived from its shareholding in PZU which were entitled to protection under the Treaty. If these rights were breached by conduct attributable to the Resnondent. Claimant is entitled to seek remedies under the Treatv.

FIGURE 8 Diagramming contract interpretation

Award

Tribunal's finding

(2) when interpreting the undertaking of due care and diligence in the operative part, as an enforceable, firm obligation, protected under international law, more reasoning was needed than merely enumerating excerpts from the preamble's text in which the parties had expressed their intent. The majority should have taken a clearer position by saying whether the preamble text served as a source of independent undertakings or how the undertaking of due care and diligence in the operative part should have been strengthened and qualified. 
Rajski's accusation, that the majority in Eureko B.V. v. Poland approached the SPA as a contract 'sans $l o i$ ', ${ }^{151}$ appears to be correct. Given that the majority consisted of Stephen Schwebel and Louis Yves Fortier, the failure to consider applicable Polish law for contract interpretation was hardly surprising. Stephen Schwebel not only participated in cases where contract interpretation was exercised in disengagement from applicable national law ${ }^{152}$ but has also clearly stated in publications that international law could be the proper law for investment contracts. ${ }^{153}$ Louis Yves Fortier somewhat later acted as an arbitrator in the Eurotunnel case discussed in Chapter 3 in which the tribunal, instead of considering applicable national law, relied on the VCLT to interpret the concession agreement. Instead of being informed by international law, ${ }^{154}$ the approach of the tribunal in Eureko B.V.v. Poland could be indeed tied to some practices observable in international commercial arbitration where arbitrators may interpret international contracts in isolation from their proper law. ${ }^{155}$ In this context it is also interesting to observe that in another case,

151 Eureko B.V. v. Republic of Poland, Ad Hoc Arbitration under the Agreement between the Kingdom of the Netherlands and the Republic of Poland on Encouragement and Reciprocal Protection of Investment, Partial Award dated 19 August 2005, Dissenting opinion, para. 5 .

152 Stephen Schwebel acted as a counsel in a contract-based Aramco case representing the claimant, whose arguments on contract interpretation, disengaged from applicable national law, were shared by the tribunal. Stephen Schwebel, 'The Kingdom of Saudi Arabia and Aramco Arbitrate the Onassis Agreement' (2010) 3 (3) Journal of World Energy Law \& Business 245, 245-256.

153 Stephen Schwebel observed, for instance, in one of his publications: 'There are many examples of contracts between States and aliens having international law as their proper law, or having international law as one of the systems of law that may govern aspects of the contract. International law may be expressly denominated as the, or a, governing law, or it may be found to be the proper law by the intent of the parties as reflected in less explicit but cumulatively determinative contractual provisions' - Stephen Schwebel, Justice in International Law: Further Selected Writings (Cambridge University Press 2011) 176.

154 Reliance on preambles for implying undertakings is not sustainable under public international law. Makane Moïse Mbengue, for instance, observes: 'Generally, in international law preambles are not capable of creating binding legal effects upon parties. Preambles are part of the narratio, not of the dispositio, ie they do not have the function of laying down legal obligations. Thus, preambular provisions are formulated in general wording and are usually not intended to constitute substantive stipulations. As such, preambles contain only exhortative clauses and do not create any legal commitment above and beyond the actual text of a treaty.'- Makane Moïse Mbengue, 'Preamble', Max Planck Encyclopedia of Public International Law <https://opil.ouplaw.com/view/10.1093/law:epil/978o19923169o/law978o19923169o-e1456> last updated September 2006, last accessed 27 August 2020.

155 Joshua Karton, 'The Arbitral Role in Contract Interpretation' (2015) 6 Journal of International Dispute Settlement 4, 10-17. See also the discussion in Chapter 2. 
Lemire v. Ukraine (II), the tribunal also disengaged from national law but was nevertheless hesitant to infer some binding obligation of result from an undertaking of best efforts to provide a radio licence ${ }^{156}$ in the settlement agreement.

At the same time, it is not certain that the conclusion would necessarily have been different if the majority had considered Polish law. ${ }^{157}$ The case, while primarily based on the SPA and its First Addendum, involved a complex factual background, and various governmental decisions in relation to whether the privatisation of PZU could provide a relevant framework for forming legitimate expectations from a foreign investor in addition to the SPA.

To sum up, even though tribunals in the cases cited do not formally refer to contract interpretation as the incidental issue, the conceptualising of contract interpretation as the incidental issue of the second order nevertheless fit well in the structure of the analyses carried. The structure of the decisionmaking in relation to the expropriation of contractual rights in the Malicorp and Vigotop tests shows that resolving a treaty claim requires deciding on a separate legal question that is subject to the terms of the contract and the applicable national law - contract termination. This question in turn requires ascertaining the content of the contract provision to some extent - contract interpretation. Similarly, tribunals may need to decide first if a contract contains implied terms that may give rise to protectable legitimate expectations under the standards of investment protection.

Furthermore, contract interpretation may be needed in contract-based proceedings to decide on a principal claim such as contract termination, contract validity, etc. In treaty-based proceedings, contract interpretation is always the incidental issue of the second order that precedes certain contract-related incidental issues. Even when applying the umbrella clause and engaging directly with contractual provisions, the treaty-based tribunal looks at contractual rights and obligations and legitimate expectations that arise in this regard, thus injecting intermediate concepts between contract interpretation and

${ }_{15}$ An obligation was worded in the settlement agreement as 'best possible efforts to consider in a positive way the application of Gala Radio to provide it with the licences for radio frequencies' - Joseph Charles Lemire v. Ukraine, ICSID Case No. ARB/o6/18, Decision on Jurisdiction and Liability dated 14 January 2010, para. 153-159.

157 Criticising the failure to apply national law to the SPA and its addendum, Zachary Douglas also expresses some doubts as to whether the result would have necessarily been different. He does not provide much clarification, though, as to how Polish law could have contributed to the reasoning of the majority or lead to the same result - Zachary Douglas, 'Nothing if Not Critical for Investment Treaty Arbitration: Occidental, Eureko and Methanex' (2006) 22 (1) Arbitration International 27, 44. 


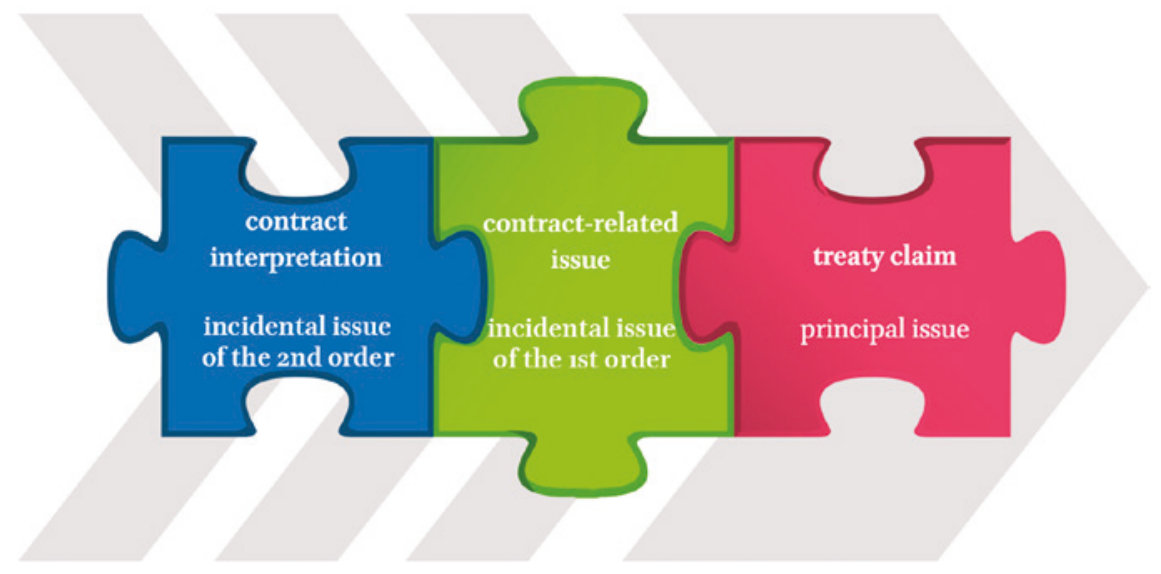

FIGURE 9 (Contract-related) decision-making in treaty-based claims

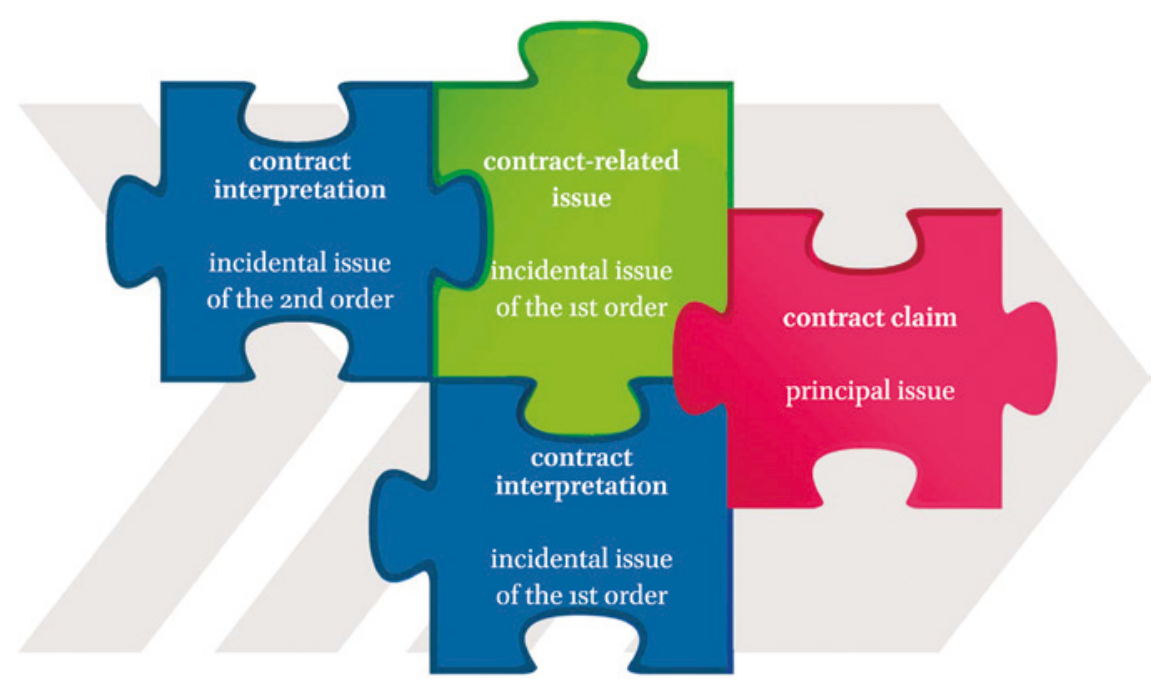

FIGURE 10 (Contract-related) decision-making in contract-based claim

the principal treaty claim. The two diagrams above summarise this point by showing that interpreting investment treaty arbitration contracts is always the incidental issue of the second order that precedes certain contract-related incidental issues, whereas in contract claims contract interpretation may be needed to solve a contractual claim and thus becomes the incidental issue of the first order. 


\subsubsection{Posing a Question about the Applicable Law}

The remaining element for conceptualising contract interpretation as the incidental issue is the requirement for some kind of a dilemma or a question regarding the applicable law. If the parties have expressly agreed on the law that is to govern their contract, the choice is generally upheld on the grounds of party autonomy, which is also recognised in the context of investment treaty arbitration. Major problems arise when the parties fail to choose the applicable law.

As discussed previously, investment treaty arbitration gives rise to a complexity that is somewhat different in nature in this regard. In a purely private international law context, the question as to which law is applicable to the incidental issue arises because of uncertainty as to which approach should prevail for incidental issues - lex fori or lex causae. ${ }^{158}$ Investment treaty arbitration does not operate with exactly the same methodological anchors for the choice of law. The problem with choosing the applicable national law for contract interpretation in investment treaty arbitration is not the outcome of indeterminacy as to which of several clearly defined alternatives should prevail (as is the case with lex fori and lex causae in private international law), but rather the result of more general and complex indeterminacy on the role and choice of national law in the context of public international law. There is no lex for in the strict sense. Arbitration regulation creates a procedural frame for treaty claims, whether they are delocalised proceedings or have a venue. Lex causae consists primarily of public international law and, with a few limited exceptions discussed before, there is no guidance on the choice of national law. This difficulty is further aggravated by indecisiveness regarding conflict of laws rules in this public international law setting - either national, and thus part of national law, or international and harmonised, and thus part of private international law in a broad sense. Above all, the precise interrelation between public international law and national laws creates its own complexity. The complexity surrounding the choice of the applicable law accordingly is more than sufficient to justify conceptualising contract interpretation as the incidental issue.

That governing law is frequently chosen by the parties in their contracts may explain the reasons why there is no plenty of analysis available of the awards made in conflict of laws cases in relation to contractual matters as a matter of practice in investment treaty arbitration. Be that as it may, even a

$15^{8}$ As discussed, the question or dilemma with applicable law appears in the situation where lex for $i$ leads to the application of foreign lex causae to the principal issue in the first place thus opening the door to a competition between the two principal approaches lex for $i$ and lex causae. 
scarce number of available awards that evidence conflict of laws analysis in relation to contracts enables one to trace some preferences for conflict of laws analysis in relation to contract interpretation in investment treaty arbitration.

William Nagelv. The Czech Republic ${ }^{159}$ is one of the relevant illustrations. The Cooperation agreement for the creation and operation of a GSM cellular telephone network in the Czech Republic is central to the tribunal's analysis. The three-partite agreement concluded between $\mathrm{MrNagel}$ (the claimant), Millicom International Cellular S.A. (a third party) and Sprava Radiokomunikaci Praha (an entity wholly owned by the state) did not contain a choice of applicable law. The failure to choose applicable law was not the only omission in the contract. The overall ambiguity of the text spanned many aspects, so the tribunal had to consider whether the Cooperation Agreement was even valid and binding for the parties at all and if so, what kind of undertakings the parties assumed vis-à-vis each other. The ultimate purpose for the tribunal to define the law applicable to the Cooperation Agreement and its interpretation was tied with issues of jurisdiction. To affirm jurisdiction, assuming that other obstacles to jurisdiction were to be overcome, the tribunal had to establish that the rights that Mr Nagel acquired under the Cooperation Agreement related to assets and investment. ${ }^{160}$ If not, the tribunal had to decline jurisdiction. This analysis would not be possible without defining and thereafter applying the governing national law.

As all roads lead to Rome, convincing all parties that Czech law was applicable to the Cooperation agreement was neither difficult, nor controversial. Both the claimant and the respondent relied on Czech law in parallel in their submissions while addressing the validity, character and content of the Cooperation Agreement. To the extent summarised in the award, the claimant has not clarified the reason for its reliance upon Czech law. ${ }^{161}$ The respondent argued that the Cooperation Agreement had to be subjected to the law of the Czech Republic because of the 'general conflict of laws principles', by which the respondent understood the overall connection of the contract with the Czech Republic, confirmed by the two connecting factors - the place of conclusion and the place of performance of the contract. ${ }^{162}$

Even in the absence of any disagreement on applicable law, the tribunal nevertheless had to cement certain connecting factors to explain the choice.

159 William Nagel v. The Czech Republic, scc Case No. 049/2002, Final Award dated 9 September 2003 .

160 Ibid, para. 316 .

161 Ibid. para. 68-69, 313-315.

162 Ibid. para. $15^{2}$. 
A blend of the connecting factors that the tribunal chose to emphasise included the nationality of a party and place of performance. A lack of disagreement between the parties on the points of applicable law also served as an argument for the tribunal in deciding that Czech law applies, though the tribunal did not interpret a lack of disagreement on applicable law as a subsequent agreement on it per se. The overall conflict of laws analysis featuring the Czech Republic as a centre of gravity for the contract took up several lines, as follows:

The Cooperation Agreement had strong links with the Government of the Czech Republic. One of the parties was a Czech State enterprise and the Agreement concerned cooperation in order to obtain rights to operate a GSM system in the Czech Republic. The Arbitral Tribunal therefore considers that Czech law should be regarded as the applicable law of the contract. Indeed, this view seems to be shared by both parties. ${ }^{163}$

Regrettably, but rather comprehensibly, the tribunal has not elaborated more and has not given more guidance that could be used for further analysis on conflict of laws in the context of investment treaty arbitration. The tribunal was more than qualified to do so given its high-profile composition, which also included a renowned expert in conflict of laws. ${ }^{164}$ It would have been helpful

163 Ibid. para. 303 .

164 The tribunal consisted of Martin Hunter (appointed by the claimant), former Justice Hans Danelius (appointed by the institution) and Herbert Kronke (appointed by the respondent). Being a Director of the Institute for Comparative Law, Conflict of laws and International Business Law of the University of Heidelberg and Former Secretary-General of UNIDROIT, Herbert Kronke is known for his work in the field of private international law and conflict of laws regulation, including as follows: Herbert Kronke, 'Capital Markets and Conflict of Laws' (2000) 286 Recueil des Cours de l'Académie de Droit International 245; Herbert Kronke, 'Applicable Law in Torts and Contracts in Cyberspace' in Katharina Boele-Woelki and Catherine Kessedjian (eds), Internet - Which Court Decides, Which Law Applies? Quel tribunal décide? Quel droit s'applique? (Kluwer Law International 1998) 6487; Herbert Kronke, 'Connecting Factors and Internationality in Conflict of Laws and Transnational Commercial Law' in Katharina Boele-Woelki and others (eds), Convergence and Divergence in Private International Law - Liber amicorum Kurt Siehr (Eleven International Publishing 2010) 57-70; Herbert Kronke, 'Transnational Commercial Law and Conflict of Laws: Institutional Co-operation and Substantive Complementarity, Inaugural Lecture, Private International Law Session, 2013' (2014) 369 Recueil des Cours de l'Académie de Droit International 9. It remains to be seen whether the issue of conflict of laws analysis will appear in another currently pending case in which Herbert Kronke sits as an arbitrator - see Itochu v. Spain, ICSID ARB/18/25<https://investmentpolicy. unctad.org/investment-dispute-settlement/cases/865/itochu-v-spain>, last accessed 26 September 2021. 
to have a more instructive assessment which would explain with more clarity that other factors have to be considered for the Cooperation Agreement as a collaborative contract where none of the parties exercise characteristic performance. Those factors are to be assessed on a balance of their relevance with place of performance being a decisive consideration.

Absence of generalised regulation on the choice of law makes the individualised approach exercised in William Nagel $v$. The Czech Republic an appropriate option as arbitrators exercising it have to make an individual assessment regarding the peculiarities of the given cases and existing links to a particular law. The individualised approach is not entirely unfamiliar for the domestic context, especially for those jurisdictions which do not have codified statutory regulation on conflict of laws rules. ${ }^{165}$ Rather than designating the relevant law as the tribunal wishes, the individualised approach attempts to justify the most connected law for a particular question by objective criteria. The latter distinguishes the approach from a discretionary ad hoc identification of the applicable law. The nationality of the parties, the place of contract conclusion, the place of contract performance, and the contract's nature may all appear among relevant considerations. Each of the connecting factors are to be assessed cumulatively in the context of the circumstances of a particular case. While distinguished from the discretionary determination of applicable law, the individualised approach inevitably bears an element of uncertainty and unpredictability. At the same time, it offers a flexibility which may be needed for the conflict of laws in investment treaty arbitration as the field that undergoes formation and where detailed conflict of laws regulation does not always deliver.

An individualised approach may take the Rome Convention as guidance. ${ }^{166}$ The Rome Convention addresses the choice of applicable law in relation to contracts' characteristic performance and captures the idea of the most closely connected law for a contract. That the Rome Convention and not the Rome I Regulation is used for this guidance is primarily explained by a preference for a general framework involving characteristic performance and overriding considerations of the most closely connected law, without restrictions tied to

165 Giuditta Cordero-Moss, 'New Trends in the Norwegian Practice on the Choice of Law Applicable to Contracts' (2012) 57 Scandinavian Studies in Law 45-61.

166 On the matter of contracts, Douglas seems to be positive that intra-EU unification, in relation to the choice of law for contracts, may point to the existence of general principles on the choice of law in relation to contractual matters - see Zachary Douglas, The International Law of Investment Claims (Cambridge University Press 2009) 90-91. 
the concrete, enumerated contractual types in the Rome I Regulation. ${ }^{167}$ To this end, one has to acknowledge an increasing recognition of the concept of characteristic performance ${ }^{168}$ with the acknowledgement of the controlling consideration of the most connected law. These two considerations, while not uniformly accepted, are nevertheless being met with increasing consensus, not only in the EU, but beyond its borders too. In this respect, the proposal in this book draws upon and adjusts the closest connection test that Benjamin Hayward ${ }^{169}$ suggests for international commercial arbitration.

If one were to determine the law applicable to these contracts based on what the most closely connected law would be, without looking at hard presumptions of characteristic performance, it is quite likely that the result would lead to the host state law. Place of performance on the territory of the host state and resulting close intertwinement with the administrative and other background law regulation of the host state, as well as the overall purpose to contribute to the development of the host state make ties of investment contracts and state contracts so close that these considerations taken together can override any other considerations for the choice of applicable law in the absence of the parties' choice. For instance, construction contracts, as a classical example of

167 Because the Inter-American Convention on Choice of Law in International Commercial has deliberately chosen not to specify concrete presumptions for characteristic performance or otherwise guiding the choice of the most closely connected law, the approach based on the Rome Convention may be more acceptable for countries in Latin America. For analysis of the approach to the choice of applicable law in the Inter-American Convention on Choice of Law in International Commercial see Friedrich K Juenger, 'The Inter-American Convention on the Law Applicable to International Contracts: Some Highlights and Comparisons' (1994) 42 American Journal of Comparative Law 381, 386-393.

168 Likewise, many national laws of the states who are not EU members attempt to clarify characteristic performance - see, for instance, Article 1125 of the Civil Code of the Republic of Belarus; Article 1211 of the Civil Code of the Russian Federation; Article 1113 of the Civil Code of the Republic of Kazakhstan; Article 119o of the Civil Code of Uzbekistan.

169 Benjamin Hayward, Conflict of Laws and Arbitral Discretion: The Closest Connection Test (Oxford University Press 2017). Peter Nygh can be also viewed as being supportive of the closest connection test based on Article 4(2) of the Rome Convention as a fallback residual rule for conflict of laws which should be favoured over lex fori-see Peter E Nygh, 'The Reasonable Expectations of the Parties as a Guide to the Choice of Law in Contract and in Tort' (1995) 251 Recueil des Cours de l'Académie de Droit International 269, 345. For examples of the reliance on the Rome I Regulation in international commercial arbitration for contracts between parties coming from the member states and for examples of commentaries pointing to the application of Rome I even for those arbitrations that do not have seats in the contracting parties see also Gary Born, International Commercial Arbitration (2nd edn, Kluwer International Law 2014) 2627. 
collaborative contracts, may necessitate equally significant performance from both parties, making it impossible to identify the characteristic performance. For this situation, the place of construction would create the most proximity. Even if, depending on the parties' undertakings, it would be possible to identify the constructor as undertaking a characteristic performance, the place of construction being the host state may nevertheless become decisive for the choice of applicable law as the most closely connected anyway. Even stronger considerations go to concession contracts because of their administrative nature. ${ }^{170}$

Overal, the most closely connected law, or the closest connected test, appears to be a widely accepted paradigm in modern regulation of conflict of laws. The paradigm may be shaped somewhat differently in various jurisdictions. Hard presumption rules relating to characteristic performance may appear in relation to some types of contracts in some jurisdictions and be unseen in others. The split in regulation would not necessarily lead to different results. The most closely connected law, or the closest connected test, determined without a look at hard presumptions, accordingly appear to be particularly suitable for the determination of the applicable law in the absence of the parties' choice for the contracts that appear in investment treaty arbitration, many of which are either entirely uncovered, or not commonly or expressly covered by the hard presumptions in the existing national and international conflict of laws regulation.

This being said a significant question remains regarding the nature of conflict of laws analysis for treaty-based tribunals. Should all treaty-based tribunals be viewed as international courts and tribunals exercising an autonomous conflict of laws analysis? Should treaty-based tribunals instead be considered in the same vein as arbitration tribunals, similarly to tribunals in international commercial arbitration and, if so, which, of numerous approaches on the choice of applicable law exercised in international commercial arbitration, is to be preferred? Furthermore and in connection with the above, what approach and which rules should treaty-based tribunals use to find out which law is applicable to a contract - international, national or both? All these questions essentially indicate the absence of the organising theory that would clarify the precise mandate of treaty-based tribunals in relation to conflict of laws and a necessity to have an agreement on specific rules or approaches for identifying the law that governs a contract. The solution proposed in this chapter

170 None of the analysed cases demonstrate that concession was subject to other laws than the law of the host state. But even if the choice is not spelled out, the host state law would most likely be applicable anyway because of the very close intertwinement of concession into the regulatory framework of the host state. 
on reliance on the Rome Convention is adjusted to contract interpretation as the incidental issue. For investment contracts, the suggested solution would rather result in the host state law.

\subsubsection{Additional Consideration: Cases with Compound Jurisdiction}

Appropriateness of treating contract interpretation as the incidental issue raises particular value for cases with compound jurisdiction and as a result evidences the viability of the concept.

As earlier discussed, this work refers to a case as 'the case with compound jurisdiction' when consent to jurisdiction in the case is both treaty-based and contract-based. ${ }^{171}$ When two types of consent appear in one proceeding, the distinctions which each of them brings are still present. The differences pertain to the jurisdictional foundation and substantive basis for the claims. When considering contract- and treaty-based claims, tribunals with compound jurisdiction apply different regulations to each of them. Each type may necessitate contract interpretation. Because contracts are not directly enforced for treaty-based claims and are directly enforced for contract-based claims, contract interpretation, it may be argued, plays a somewhat different role for each claim. ${ }^{172}$ At the same time, it is difficult to understand why the methodology used to address the same issue - contract interpretation - should differ in principle from one system to another, especially when both claims meet in a single proceeding and both depend on interpretation of the same contract or even

171 Of the analysed cases with elements of contract interpretation, tribunals have compound jurisdiction in the cases as follows: Khan Resources Inc., Khan Resources B.V., and Cauc Holding Company Ltd. v. The Government of Mongolia, UNCITRAL; Joseph Charles Lemire v. Ukraine, ICSID Case No. ARB/o6/18; Burlington Resources Inc. v. Republic of Ecuador, ICSID Case No. ARB/o8/5; Caratube International Oil Company LLP and Devincci Salah Hourani v. Republic of Kazakhstan, ICSID Case No. ARB/13/13; Duke Energy Electroquil Partners \& Electroquil S.A. v. Republic of Ecuador, ICsid Case No. ARB/04/19; Noble Energy, Inc. and Machalapower Cia. Ltda. v. The Republic of Ecuador and Consejo Nacional de Electricidad, ICSID Case No. ARB / o5/12; Occidental Petroleum Corporation and Occidental Exploration and Production Companyv. The Republic of Ecuador (II), ICSID Case No. ARB / o6/11; Perenco Ecuador Ltd. v. The Republic of Ecuador and Empresa Estatal Petróleos del Ecuador (Petroecuador), ICSID Case No. ARB/o8/6.

172 The distinction in the treatment of contract interpretation in treaty-based proceedings from treating it as the principal issue or along with the principal contract-centred issues in domestic litigation or in international commercial arbitration lies in the level of the subsidiarity. Whenever contract interpretation is conclusively decided in proceedings in which contract-centred issues constitute the principal issues, contract interpretation would most likely have res judicata status. However, when contract interpretation is decided as the incidental issue of the second order in investment treaty arbitration, this would not be mandatory for other proceedings. 
the same contractual provisions. Furthermore, in addition to bringing consistency in methodology, the concept of the incidental issue may enhance procedural economy. Tribunals may find it inappropriate to 'redo' interpretation for a treaty-based claim, once it is exercised in the framework of contract-based claims. ${ }^{173}$

In other words, contract interpretation remains the same phenomenon despite the different basis for the tribunal's jurisdiction - a contract or a treaty. ${ }^{174}$ Treating contract interpretation as the incidental issue both in the framework of considering contract-based claims and treaty-based claims would achieve uniformity and predictability associated with the application of national law to contract interpretation. In fact, of the identified cases with elements of contract interpretation where tribunals possessed compound jurisdiction, national law informed contract interpretation in the majority of them. ${ }^{175}$

\subsection{National Law in Operation through the Concept of an Incidental Issue}

\subsubsection{Jura Novit Curia}

When approaching contract interpretation through the concept of an incidental issue, treaty-based tribunals have to ascertain the content of national law applicable to the contract. Various scenarios may arise. Parties to a dispute

173 See, for instance, Joseph Charles Lemire v. Ukraine, Decision on Jurisdiction and Liability dated 14 January 2010, para.487-489. At the same time the approach to interpretation adopted in the contract-related part of the claim and thereafter relied on in a treatyrelated part is open to criticism. The criticism though does not change the point made here, namely that there are no grounds for treating contract interpretation differently in cases with compound jurisdiction, and contract interpretation exercised in relation to contractual claims may well be relied on in the part where a treaty claim is considered.

174 See also the discussion in Chapter 4 on distinctions between contract interpretation and other peculiar types of analysis in investment treaty arbitration.

175 Of eight cases with compound jurisdiction, national law informed contract interpretation in six of them: Khan Resources Inc., Khan Resources B.V., and Cauc Holding Company Ltd. v. The Government of Mongolia, UNCITRAL; Burlington Resources Inc. v. Republic of Ecuador, ICSID Case No. ARB/o8/5; Caratube International Oil Company LLP and Devincci Salah Hourani v. Republic of Kazakhstan, ICSID Case No. ARB/13/13; Duke Energy Electroquil Partners \& Electroquil S.A. v. Republic of Ecuador, ICSID Case No. ARB/O4/19; Occidental Petroleum Corporation and Occidental Exploration and Production Company v. The Republic of Ecuador (II), ICSID Case No. ARB/o6/11; Perenco Ecuador Ltd. v. The Republic of Ecuador and Empresa Estatal Petróleos del Ecuador (Petroecuador), ICsID Case No. ARB/o8/6. 
may build their arguments in relation to contract interpretation on national law, and provide sufficient elucidation of the relevant content of national law. Parties may also misrepresent the content of national law or entirely omit references to national law and be silent on its potentially critical capacity to overcome literal interpretation. For all of these scenarios, in order to discharge their adjudicatory function, treaty-based tribunals need to be in a position to make their own legal inferences from the factual basis proven by the parties, to verify the parties' submissions in relation to the content of national law applicable to contract interpretation, to invoke national law independently, where needed, and to apply it to contract interpretation.

The absence of direct normative regulation of the principle in investment treaty arbitration ${ }^{176}$ opens a possibility for different opinions on its content. Of the various facets of jura novit curia, the most controversial power is not relevant for contract interpretation in investment treaty arbitration. This power relates to ordering, independently from the parties' pleadings, remedies that were not asked for but that follow from the applicable sources of law. ${ }^{177}$ The irrelevance of this power for the context of contract interpretation in investment treaty arbitration, however, does not render the principle of jura novit curia entirely uncontroversial. Opposing views reflect the existent disagreements over the content of the principle jura novit curia and ongoing debate on the role of national law in investment treaty arbitration. One may perceive the principle quite literally as 'arbitrators know the law' and on that basis reject the extension of the principle to national law. This perspective would be premised on the understanding that the only law which arbitrators are supposed 'to know' is international law. Alternatively, one may perceive the principle as a power to invoke, ascertain and apply national law within the restrictions imposed by the requirements of due process, and on that basis acknowledge

${ }_{17} 6$ Jura novit curia does not find textual expression in the IIAs. Laws of the seat for localised arbitration and procedural regulation for delocalised ICsID proceedings do not directly and explicitly address the principle either. Similarly, arbitration rules are equally silent on the principle (with a rare exception in Article 22 (1) (iii) of the LCIA Arbitration Rules). While not addressing the principle explicitly, procedural regulation remains nevertheless of relevance for shaping the principle of jura novit curia - see national reports on jura novit curia assembled and analysed in Franco Ferrari and Giuditta Cordero-Moss (eds), Iura Novit Curia in International Arbitration (Juris Publishing 2018).

177 See, for instance, Bogdanov v. Moldova (I), where the sole arbitrator concluded that the tribunal 'remains free, within the borders of the applicable law ... to give the legal qualifcations and determine the legal consequences that it deems appropriate, even if they were not pleaded by the parties.' - Bogdanov v. Moldova (I), scc Case 93/2004, Award dated 22 September 2005, para. 69 . 
its extension to national law in investment treaty arbitration. This perspective would not expect arbitrators 'to know' the law, but would rather accept that they may invoke it, ascertain its content and apply it under the condition of giving the parties the opportunity to present their case and of treating the parties equally. ${ }^{178}$ In what relates to the role of national law in investment treaty arbitration, one may align treaty-based tribunals exclusively with international courts, and on that basis deny extension of jura novit curia to national law. ${ }^{179}$

178 Friedrich Rosenfeld, 'Iura Novit Curia in International Law' in Franco Ferrari and Giuditta Cordero-Moss (eds), Iura Novit Curia in International Arbitration (Juris Publishing 2018) 427-428; Mauro Rubino-Sammartano, International Arbitration Law and Practice (3rd edn, Juris Publishing 2014) 684-685. Rather exceptionally, newly developed guidance on the conduct of international arbitration - the Rules on the Efficient Conduct of Proceedings in International Arbitration (the Prague Rules) - explicitly address jura novit curia in Article 7.

179 For instance, in Murphy Exploration \& Production Company International v. Republic of Ecuador (II) the tribunal expressly acknowledged that 'municipal law in an international law context is treated as fact' and on that basis denied an extension of the principle of jura novit curia to national law - Murphy Exploration \& Production Company - International v. The Republic of Ecuador (II), PCA Case No. 2012-16, Partial Final Award dated 6 May 2016, para. 361. In doing so, the tribunal relied upon Oliver Dörr and Kirsten Schmalenbach (eds), Vienna Convention on the Law of Treaties: A Commentary (Springer 2012) 824. The case is also discussed in the section on distinctions between contract interpretation and fact-finding. See also Sourgens, who by referring to Fraport AG Airport Services Worldwide $v$. Phillipines suggests that annulment committees support the proposition that jura novit curia does not apply to national law - Frédéric Gilles Sourgens, A Nascent Common Law: The Process of Decisionmaking in International Legal Disputes Between States and Foreign Investors (Brill/Martinus Nijhoff 2015) 94. It appears though that what was unacceptable for the annulment committee in the Fraport case was rather procedural violations associated with the exercise of the tribunal's efforts on the ascertainment of the content of national law. By citing para.117 of the Decision on the Application for Annulment of Fraport AG Frankfurt Airport Services Worldwide dated 23 December 2010, Fraport AG Frankfurt Airport Services Worldwide v. The Republic of the Philippines, and characterising it as a blank denial of the principle of jura novit curia in respect to national law, Frédéric Gilles Sourgens does not include the final sentence in the same statement of the decision. The sentence in fact clarifies that the annulment committee did not consider that the original tribunal was deprived of the right to invoke and ascertain the content of national law; the committee was rather concerned about procedural aspects of the exercise of this power: 'How the Tribunal proceeded on this issue is the subject of the Committee's analysis in the next section of this Decision.' [emphasis added] - see Fraport AG Frankfurt Airport Services Worldwide v. The Republic of the Philippines, ICSID Case No. ARB/ 03/25, Decision on the Application for Annulment of Fraport AG Frankfurt Airport Services Worldwide dated 23 December 2010, para.119-247. A distinction between the principle of jura novit curia and the principle of due process together with their close interplay have been helpfully clarified in another decision of an annulment committee in Caratube v. Kazakhstan - see Caratube International Oil Company LLP v. Republic 
Alternatively, one may accept treaty-based tribunals as being tribunals applying national law to various questions along with international law, and on this basis recognise that jura novit curia equally extends to national law. ${ }^{180}$

This study supports the extension of the principle of jura novit curia to national law in investment treaty arbitration. The extension is premised on a flexible understanding of the content of the principle as a kind of normative frame for the allocation of the joint responsibility between the tribunal and the parties on the ascertainment of the content of the relevant national law. By saying that treaty-based tribunals should act under the principle of jura novit curia and that the principle extends to national law, one does not suggest that treaty-based tribunals should know national law. The suggestion merely enables the tribunals to retain judicial integrity by recognising their power to independently invoke and investigate any issue of national law which is relevant for the verification and exercise of their mandate. ${ }^{181}$ As a result, treaty-based tribunals are not constrained by parties' elucidation and may exercise their own efforts for invoking, ascertaining and applying national law to contract interpretation. Their power is not unlimited. Principles of due process control the exercise of jura novit curia.

The extension of the principle of jura novit curia to national law in investment treaty arbitration is also premised on the understanding that the existing debate about the status of national law does not impede it. While certain investment regimes (for instance, the ECT or the NAFTA) expressly recognise only international law as being applicable as lex causae, that in and of itself does not exclude the relevance of national laws to those questions which are governed by them. Rather than focusing on the primary applicable law in investment treaty arbitration, this work suggests that one should look at the tribunal's mandate to resolve disputes which have a substantial national law

of Kazakhstan, ICSID Case No. ARB/o8/12, Decision on the Annulment Application of Caratube International Oil Company LLP dated 21 February 2014, para. 90-96.

180 Zachary Douglas, The International Law of Investment Claims (Cambridge University Press 2009) 70, Jarrod Hepburn, Domestic Law in International Investment Arbitration (Oxford University Press 2017) 104-138; Hege Elisabeth Kjos, Applicable Law in Investor-State Arbitration: The Interplay Between National and International Law (Oxford University Press 2013) 213-271.

181 The tribunals have explicitly acknowledged their right to ascertain the content of national law in, for instance, Garanti Koza v. Turkmenistan, ICSID Case No. ARB /11/2O, Award dated 19 December 2016, para. 331; Metal-Tech Ltd.v Uzbekistan, ICSID Case No. AR B/10/3, Award dated 4 October 2013, para. 287; Anglo American PLC v. Bolivarian Republic of Venezuela, ICSID Case No.ARB(AF)/14/1, Final Award dated 18 January 2019, para.217-218; Vestey Group Ltd v. Bolivarian Republic of Venezuela, ICSID Case No. ARB/o6/4, Award dated 15 April 2016, para. 118. 
component. Interpreting contracts incidentally by applying national law is but a part of this mandate.

Further, internal controversy or unsettled character of the national regulation on certain issue shall not impede reliance on jura novit curia. ${ }^{182}$ As investment treaty arbitration does not have a system of referral that would enable tribunals to delegate decisions on these issues to the competent domestic body, ${ }^{183}$ they have to engage with these issues first. Because such an ascertainment would be done in the context of the incidental issue, its results would bear limited consequences, if at all, for the subsequent application of national law in the respective jurisdiction. In other words, the authority of treaty-based tribunals to form an opinion on the content of national law would be the role of a dispute-settlement function. In exercising it, tribunals would not perform the law-development function in any respect. Accordingly, their findings on the unsettling or controversial issue under national law would not be decisive

182 This section deals with available but for some reason controversial or unsettled regulation, but not with lacunae, in national law. Chapter 2 has established that there is no and could not be lacunae in national law in relation to contract interpretation. In what relates to lacunae, there is a common perception in the context of ICSID arbitration and more generally that international law may fill lacunae in national law regulation or exercise a supplementary function - W Michael Reisman, 'The Regime for Lacunae in the ICSID Choice of Law Provision and the Question of Its Threshold' (2000) 15(2) ICSID Review - Foreign Investment Law Journal 362; Christoph Schreuer and others, The ICSID Convention: A Commentary (2nd edn, Cambridge University Press 2009) 620-627. The corrective function of international law is addressed below.

183 A system of referral or preliminary ruling is well-established in the EU - see Mads Andenas (ed), Article 177 References to the European Court: Policy and Practice (Butterworth 1994). The idea of referral has been suggested by some authors as a model for the ISDS reform, though the subject of referral was limited to international law and has not been covered with regards to national law - see Christoph Schreuer, 'Preliminary Rulings in Investment Arbitration' in Karl P Sauvant and Michael Chiswick-Patterson (eds), Appeals Mechanism in International Investment Disputes (Oxford University Press 2008) 207-212; Katharina Diel-Gligor, Towards Consistency in International Investment Jurisprudence: A Preliminary Ruling System for ICSID Arbitration (Brill Nijhoff 2017). In a domestic context, one can find some peculiar forms of resolving controversy between certain acts. For instance, under Article 10 (6) of the Code of Civil Procedure of Ukraine, if the court finds that a certain law or other regulation contradicts the Constitution of Ukraine, the court can avoid applying this law or regulation and apply the Constitution as an act of direct force. In this situation, the court then has to ask the Constitutional Court of Ukraine to address the issue of the validity of that law or regulation which the court decided not to apply. On the interaction between constitutional and civil procedures under Ukrainian law, see, for instance, Ірина Берестова, ‘Форми взаємозв'язку конституційного провадження i цивільного судочинства' (2018) 10 Підприємництво, господарство і право 16о [Iryna Berestova, 'The Forms of Interactions between Constitutional and Civil Procedures' (2018) Entrepreneurship, Property and Law 16o]. 
regarding elaborating a resolution of the same controversy within the domestic legal order. Quite the opposite: the way national law is construed and applied by the high judicial authority in a given country, or clarified by the competent domestic authority, frequently guides treaty-based tribunals, sometimes even leading them to be decisive about their conclusions. ${ }^{184}$

Two cases illustrate this last point. In Chevron Corporation and Texaco Petroleum Corporation v. The Republic of Ecuador, ${ }^{185}$ the tribunal had to deal with the Constitution of the Republic of Ecuador to decide whether the settlement agreement ${ }^{186}$ finally resolved all possible collective environmental claims against two investors. Interpretation of the release provisions in the settlement agreement appeared central to the decision and had to be decided in light of the interpretation of the constitutional provisions. ${ }^{187}$ In another case, Ceskoslovenska obchodni banka, a.s. v. Slovak Republic, ${ }^{188}$ the tribunal had to deal with a complex interplay between the Civil Code and the Commercial Code of the Czech Republic. ${ }^{189}$ Not only did the tribunal have to find out

184 Some FTAS may even expressly state that when interpreting national law tribunals have to give deference to domestic interpretation exercised in that jurisdiction. See, for instance, Article 3.42 of EU-Vietnam FTA which provides: 'For greater certainty, the Tribunal and the Appeal Tribunal shall be bound by the interpretation given to the domestic law by the courts or authorities which are competent to interpret the relevant domestic law, and any meaning given to the relevant domestic law made by the Tribunal and the Appeal Tribunal shall not be binding upon the courts and the authorities of either Party.'

185 Chevron Corporation and Texaco Petroleum Corporation v. The Republic of Ecuador, UnCITRAL, PCA No.2009-23, First Partial Award on Track I dated 17 September 2013.

186 The settlement agreement was executed between Ecuador, the state-owned enterprise Petroecuador, and one of the investors/claimants in the TexPet proceedings on 4 May 1995, which provided that the parties undertook to release all of its obligations and liability for environmental impact arising out of the operation of their consortium.

187 Technically, the tribunal based its analysis on the content of the release clause in the part dealing with the 'Legal Effect' of the contractual provision and not in the part on 'Legal Interpretation'. Nevertheless, the analysis construed the content of the release provision and thus captured contract interpretation as an analytical effort. (Chevron Corporation and Texaco Petroleum Corporation v. The Republic of Ecuador, UNCITRAL, PCA No.20o9-23, First Partial Award on Track I dated 17 September 2013, para. 92-110). In the part labelled 'contract interpretation', the tribunal dealt with the interpretation of the reference to 'principal' in the settlement agreement. The tribunal, in particular, considered whether Chevron could benefit from the settlement agreement as a principal (Ibid. para. 62-91).

188 Ceskoslovenska obchodni banka, a.s. v. Slovak Republic, ICSID Case No.ARB/97/4. The jurisdiction of the tribunal was indeed based on the Czech Republic-Slovak Republic BIT, but the claim on the merits was contract-based.

189 The complexity of relations between civil and commercial regulation is also known for other jurisdictions. In Ukraine, since the adoption in 2003 of the Commercial Code of Ukraine (adopted 16 January 2003, entered into force 1 January 2004), and the Civil Code of Ukraine No. 435-IV (entered into force on 1 January 2004), there is an ongoing 
which act applied to the situation at stake, but it also had to take a view on the relevance and possible interplay of the specific regulation on contract interpretation in both acts (Section 35 of the Civil Code and Section 266 of the Commercial Code). Furthermore, if the tribunal in Chevron Corporation and Texaco Petroleum Corporation v. The Republic of Ecuador did not find the issue of construing the content of the constitutional provisions particularly burdensome or complicated, ${ }^{190}$ the tribunal in Ceskoslovenska obchodni banka, a.s. v. Slovak Republic openly recognised that the interplay between the interpretative provisions of the Civil Code and the Commercial Code was 'a delicate and debated matter under Czech law.'191 Yet that did not stop the tribunal from analysing the provisions in light of the parties' submissions, and the expert opinions and practices of the high courts in the Czech Republic in relation to the matter. Belonging to incidental construction of the national law, these findings do not have any bearing on domestic legal orders and merely enable the tribunals to discharge their treaty mandates.

\subsubsection{Expert Testimony}

While this work suggests that tribunals may rely on the principle of jura novit curia in their approach to contract interpretation as the incidental issue, one has to recognise that parties' clarification still appears as a primary source for construing the content of relevant national law. This, in turn, leads to the consideration of diverse material ranging from counsels' clarification to expert opinions and summaries of judicial practice. Recognising that tribunals may act on the basis of jura novit curia in respect to national law, this study was unable to identify a single case in which, in the absence of the parties' arguments on the relevance of national law for contract interpretation, tribunals have independently invoked national law. Similarly, this study was unable to identify a single case in which tribunals chose themselves to appoint an expert on points of national law in relation to contract interpretation. A lack of examples

debate on various aspects of the interrelations between the two. See, for instance, The Highest Commercial Code of Ukraine, Clarifying Letter as of 7 April 2008 No.o1-8-211 'On Some Questions on Application of Civil and Commercial Code of Ukraine' (Вищий Господарський Суд України, Інформаційний лист від о7 квітня 2008 N 01-8/211 “Про деякі питання практики застосування норм Цивільного та Господарського кодексів України.")

190 The tribunal characterised its task as being 'relatively short and uncomplicated' - see Chevron Corporation and Texaco Petroleum Corporation v. The Republic of Ecuador, UNCITRAL, PCA No.2009-23, First Partial Award on Track I dated 17 September 2013, para. 34, 62.

191 Ceskoslovenska obchodni banka, a.s. v. Slovak Republic, ICSID Case No.ARB/97/4, Award dated 29 December 2004, para. 88. 
does not overturn though the powerful potential that jura novit curia gives to tribunals as a matter of principle within the safeguards set by due process.

The concept of the incidental issue assists in safeguarding the quality of reasoning also in those situations where there is a strong temptation to delegate a decision on contract interpretation to experts. ${ }^{192}$ Overall, there is nothing wrong with a tribunal relying entirely or in part on expert conclusions to ascertain the content of contractual provisions if all procedural requirements are safeguarded. ${ }^{193}$ This it actually what the parties aim to achieve when they involve experts in proceedings, and this is what the role of experts is all about the facilitation of the tribunal's task. Problems may arise when tribunals substantially reduce their own analytical efforts in relation to the ascertainment of the content of contractual provisions and essentially substitute it with observations on the reasonableness and persuasiveness of expert findings. There is

192 Somewhat abbreviated reasoning which relied upon expert opinions can be found in two conjoined ICSID arbitrations, Gemplus S.A., SLP S.A., Gemplus Industrial S.A. de C.V. v. The United Mexican States and Talsud S.A. v. The United Mexican States, and are further contrasted with Gambrinus, Corp. v. Bolivarian Republic of Venezuela. See Gemplus S.A., SLP S.A., Gemplus Industrial S.A. de C.V.v. The United Mexican States, ICSID Case No.ARB(AF)/ 04/3, Award dated 16 June 2010, para 5-28; Talsud S.A. v. The United Mexican States, ICSID Case No. ARB(AF)/o4/4, Award dated 16 June 2010, para 5-28; Gambrinus Corp. v. Bolivarian Republic of Venezuela, ICSID Case No. ARB/11/31, Award of the Tribunal dated 15 June 2015, para. 265-277. (Subsequent attempts to annul an award on the basis that the tribunal failed to consider the parties' intent, and therefore to apply the proper law that mandated consideration of the parties' intent, were not successful.)

193 In admitting expert opinions and in assessing evidentiary value, tribunals have to ensure due process, the fair treatment of parties, etc. For a detailed discussion of various procedural implications that appear in connection with the use of experts in investment treaty arbitration, see Frédéric G Sourgens, Kabir Duggal and Ian A Laird, Evidence in International Investment Arbitration (Oxford University Press 2018) 225-233; Kate Parlett, 'Parties' Engagement with Experts in International Litigation' (2018) 9 (3) Journal of International Dispute Settlement 440; Brendan Plant, 'Expert Evidence and the Challenge of Procedural Reform in International Dispute Settlement'(2018) 9 (3) Journal of International Dispute Settlement 464; Mélida Hodgson and Melissa Stewart, 'Experts in Investor-State Arbitration: The Tribunal as Gatekeeper'(2018) 9 (3) Journal of International Dispute Settlement 453. See also, Laurence Boisson de Chazournes, Makane Moise Mbengue, Rukmini Das and Guillaume Gros observing differences in the role of experts in various types of international litigation, at the same time acknowledging that due process requirements impose and shape 'some universal characteristics of the functions, qualities and mode of functioning of experts'- Laurence Boisson de Chazournes and others, 'One Size does not Fit All - Uses of Experts before International Courts and Tribunals: An Insight into the Practice' (2018) 9 (3) Journal of International Dispute Settlement 477, 504 . 
high risk in this as so far as awards permit one to ascertain, ${ }^{194}$ none of the expert opinions invoked by parties and assessed by tribunals stop exclusively at clarifying the interpretative rules or establishing trade usages, experts rather give their opinions on the content of specific contractual provisions and their effect. ${ }^{195}$ Falling short in terms of reasoning can accordingly be viewed as a delegation of the adjudicatory function to experts, in relation to contract interpretation. While not necessarily leading to an annullable error, delegation in the form of abbreviated reasoning based on expert opinions may undermine the quality of a tribunal's legal reasoning. ${ }^{196}$ Treating contract interpretation as the incidental issue in turn assists in keeping focus on the adjudicatory function of the tribunal. The tribunals, not experts, are ultimately entrusted to discharge their adjudicatory function which in the context of investment treaty arbitration also means construing the content of contractual provisions and integrating it into a bigger analytical effort in relation to a treaty claim.

Rather exceptionally to the above, when an expert opinion relates to the establishment of trade usages or other aspects related to a certain industry (oil exportation, construction, etc.), which tribunals are not expected to know or ascertain independently and to which jura novit curia does not extend, tribunals may well assess the persuasiveness of the confirmations of the trade usages without being expected to demonstrate the same degree of independent reasoning in comparison to the interpretation on the basis of national law. At the same time, the precise role of trade usages and industry practices

194 Not all awards list all questions that were put to experts, not all awards cite expert opinions in extenso or otherwise make a clear summary of what experts had to clarify.

195 See discussion of the expert opinions in Ceskoslovenska Obchodni Banka, A.S. v. The Slovak Republic, ICsid Case No. ARB/97/4, Chevron Corporation and Texaco Petroleum Corporation v. The Republic of Ecuador, PCA Case No. 2009-23, Daimler Financial Services AGv. Argentine Republic, ICSID Case No. ARB/ 5/1, Gambrinus, Corp. v. Bolivarian Republic of Venezuela, ICSID Case No. ARB/11/31, Ampal-American Israel Corporation and others v. Arab Republic of Egypt, ICsID Case No. ARB/12/11, ACP Axos Capital GmbH v. Republic of Kosovo, ICSID Case No. ARB/15/22; Gemplus S.A., SLP S.A., Gemplus Industrial S.A. de C.V.v. The United Mexican States, ICsid Case No. ARB (AF)/o4/3; Talsud S.A. v. The United Mexican States, ICSID Case No. ARB(AF)/04/4; William Nagel v. The Czech Republic, sCC Case No. 049/2002; Occidental Petroleum Corporation and Occidental Exploration and Production Company v. The Republic of Ecuador, ICSID Case No. ARB/o6/11; Sergei Paushok, CJSC Golden East Company and CJSC Vostokneftegaz Companyv. The Government of Mongolia; Georg Gavrilovic and Gavrilovic d.o.o. v. Republic of Croatia, ICsid Case No. ARB/12/39; Bayindir Insaat Turizm Ticaret Ve Sanayi A.S. v. Islamic Republic of Pakistan, ICSID Case No. ARB / o3/29.

196 On the theoretical account of what a proper role of an expert implies in litigation, see James Flett, 'When is an Expert not an Expert?' in (2018) 9 (3) Journal of International Dispute Settlement $35^{2}, 35^{2-} 35^{6}$. 
for contract interpretation are still to be determined by the relevant national law. ${ }^{197}$

\subsubsection{Why Does It Matter?}

A limited, if any, review of the application of national laws to contract interpretation at the setting aside and enforcement stage calls for more efforts to be made within the proceedings. Approaching contract interpretation as an incidental issue assists in not omitting the relevance of national law to contract interpretation and its application. Ultimately, it assists in getting it right in the first place.

While procedures on annulment, setting aside or vacation of arbitral awards do not encompass a full scope of appeal as to the correctness of contract interpretation, it nevertheless is not entirely blind to it. A failure to apply national law to contract interpretation may potentially fall into a category of excess of the tribunal's power or mandate and thus serves as a ground for annulment, ${ }^{198}$ setting an award aside ${ }^{199}$ or the vacation of an award. ${ }^{200}$ Furthermore, an exercise of contract interpretation may trigger other grounds for annulment, setting aside or vacation, which pertain to due process ${ }^{201}$ and the reasoning in the award. ${ }^{202}$

197 See Chevron Corporation (USA) and Texaco Petroleum Company (USA) v. The Republic of Ecuador, UnCitral, PCA Case No. 34877, Partial Award on the Merits dated 3o March 2010, para. 450-451 and discussion of Garanti Koza v. Turkmenistan (ICsID Case No. ARB/ 11/20) Award dated 19 December 2016, para.15o, 333-337. Some laws expressly enable trade usages to be considered as a supporting argument in cases where the literal reading of a contract is not sufficient. Article 213 (4) of the Civil Code of Ukraine No. 435-IV (entered into force on 1 January 2004) <https://zakon.rada.gov.ua/laws/show/435-15?lang=ru>, last accessed on 25 June 2021, recognises trade usages among factors to be considered for contract interpretation as a last resort including post-contractual conduct and practice established between the parties.

198 Article $5^{2}$ (1) (b) of the ICsid Convention.

199 Article 1065 (1) (c) of the Dutch Code of Civil Procedure 2015; Article 1520 (3) of the French Code of Civil Procedure, Section 34 (3) of the Swedish Arbitration Act; Section 68 (2) (e) and Section 69 (appeal on point of law) of the English Arbitration Act 1996.

200 Section 10 (a) (4) of the United States Federal Arbitration Act.

201 Article 52 (1) (d) of the ICsid Convention, Section 34 (7) of the Swedish Arbitration Act, Article 1520 (4) of the French Code of Civil Procedure, Section 10 (a) (3) of the United States Federal Arbitration Act, Article 1065 (1) (d) of the Dutch Code of Civil Procedure 2015; Section 68 (2) (a), Section 68 (2) (c), Section 68 (2) (i) of the English Arbitration Act 1996.

202 Article 52 (1) (e) of the ICsid Convention, Article 1065 (1) (d) of the Dutch Code of Civil Procedure 2015; Section 68 (2) (d), Section 68 (2) (f) of the English Arbitration Act 1969. 
The threshold for the revision, in respect to contract interpretation, is necessarily high for all the described grounds, regardless of whether the revision is conducted by the ICSID annulment committee (as is the case for delocalised proceedings), or by state courts (as is the case for proceedings with a seat). Only those violations which amount to a manifest excessive exercise of mandate or power, a violation of due process, or with no reasons given in an award, justify award cancellation. It is, accordingly, not surprising that none of the analysed cases with elements of contract interpretation in fact evidence a successful annulment, setting aside or vacation of an award because of the irregularities connected to contract interpretation. ${ }^{203}$

The reasoning of the ICSID annulment committees cited below assists to clarify the high threshold for annulment, and thus valuably reinforces the importance of getting contract interpretation right, from the very beginning. In MTD Equity Sdn. Bhd. and MTD Chile S.A. v. Republic of Chile, the annulment committee was clear enough to identify that analysis of FET in respect to rights and expectations arising under the contract, also necessitated an analysis of national law. ${ }^{204}$ Rejecting the argument of the manifest excessive exercise of

203 Out of 91 analysed cases with elements of contract interpretation conducted under the ICSID Convention (identified from Annex IV), annulment proceedings took place in 42 cases. Only six awards were either fully or partially annulled: CMS Gas Transmission Company v. The Argentine Republic, ICSID Case No. ARB/o1/8; Compañiá de Aguas del Aconquija S.A. and Vivendi Universal S.A. v. Argentine Republic, ICSID Case No. ARB/97/ 3; Enron Corporation and Ponderosa Assets, L.P. v. Argentine Republic, ICSID Case No. ARB/o1/3; Malaysian Historical Salvors, SDN, BHD v. The Government of Malaysia, ICSID Case No. ARB/o5/10; Occidental Petroleum Corporation and Occidental Exploration and Production Companyv. The Republic of Ecuador (II), ICSID Case No. ARB/o6/11; Venezuela Holdings, B.V., et al (case formerly known as Mobil Corporation, Venezuela Holdings, B.V., et al.) v. Bolivarian Republic of Venezuela, ICSID Case No. ARB/07/27. Except for Vivendi (Compañiá de Aguas del Aconquija S.A. and Vivendi Universal S.A. v. Argentine Republic, ICSID Case No. ARB/97/3) discussed in Chapter 4, neither award was annulled because of the irregularities tied to contract interpretation. In remaining proceedings, that is, 36 cases with elements of contract interpretation which were conducted in arbitration proceedings with a seat (including those conducted under the ICSID Additional Facility Rules), only one award was annulled (Lee John Beck and Central Asian Development Corporation v. Kyrgyz Republic), for reasons unrelated to contract interpretation. Even for Eureko B.V. v. Republic of Poland discussed earlier in this chapter, the tribunal's failure to consider Polish law applicable to contract interpretation was not sufficient to set an award aside on the ground of the abuse of power in the competent state court of Belgium - see Judgment of the Court of First Instance of Brussels of 23 November 20o6, excerpts of the translation available at <https://www.italaw.com/sites/default/files/case-documents/ itao304_o.pdf $>$, last accessed on 25 June 2021.

204 MTD Equity Sdn. Bhd. and MTD Chile S.A. v. Republic of Chile, ICSID Case No. ARB/o1/7, Decision on Annulment dated 21 March 2007, para. 72. 
its power by the original tribunal, the committee elucidated that it was only the application of the national law to the contract that fell within the scope of revision in the annulment procedure, but not the correctness of its application. ${ }^{205}$ Similarly, in Malicorp Limited v. Arab Republic of Egypt ${ }^{206}$ and Adem Dogan v. Turkmenistan, ${ }^{207}$ the annulment committees agreed that the application of national law to a contract was subject to review in the annulment proceedings, whereas verification of the correctness of its application was not. In Malicorp Limited $v$. Arab Republic of Egypt, the annulment committee additionally specified that verification of the application of national law could not stop at mere assurances of the original tribunal. The annulment committee had to verify that the original tribunal in fact applied the law it claimed to be applicable. ${ }^{208}$ While being sceptical about the significance of the national law for the annulment in the first place, ${ }^{209}$ the annulment committee in Azurix Corp. $v$. Argentina also affirmed that the correctness of the application of national law pertained to the merits of the case and thus could not be subjected to the annulment review. ${ }^{210}$ In AES Summit Generation Limited and AES-Tisza Erömü $K f t v$ Hungary (II), being dissatisfied with the tribunal's findings, the investors failed to persuade the annulment committee that the allegedly frivolous reasons relating to interpretation of the settlement agreement ${ }^{211}$ amounted to no reasons at all. ${ }^{212}$ The annulment committee specified that its task was to verify

205 Ibid. para. 75 .

206 Malicorp Limited v. Arab Republic of Egypt, ICSID Case No. ARB/o8/18, Decision on the Application for Annulment of Malicorp Limited dated 3 July 2013, para.154-155.

207 Adem Dogan v. Turkmenistan, ICSID Case No. ARB/og/9, Decision on Annulment dated 15 January 2016, para. 15 o.

208 Malicorp Limited v. Arab Republic of Egypt, ICSID Case No. ARB/08/18, Decision on the Application for Annulment of Malicorp Limited dated 3 July 2013, para.157 (the committee found the reliance of the original tribunal on the reasoning of another arbitral tribunal based on national law in respect to the same contract to be a proper confirmation that the original tribunal 'in fact applied Egyptian law without performing de novo the entire review and analysis of Egyptian (aw.').

209 Azurix Corp. v. The Argentine Republic (I), ICSID Case No. ARB/o1/12, Decision on the Application for Annulment of the Argentine Republic dated 1 September 20o9, para. $146-153$.

210 Ibid. 169.

211 The investors essentially attacked the tribunal's interpretation of the provision on 'change in law' in the settlement agreement which, coupled with the conclusion on the lack of a stabilisation clause, led the tribunal to a finding on the lack of legitimate expectations of foreign investments.

212 AES Summit Generation Limited and AES-Tisza Erömü Kft. v. Republic of Hungary (II), ICSID Case No. ARB/o7/22), Decision of the Ad Hoc Committee on the Application for Annulment dated 29 June 2012, para. 54. 
that the original tribunal gave reasons, but not to check that those reasons were 'convincing' or 'good.'.213

In what relates to enforcement, this stage enables even less possibility for control over the exercise of contract interpretation than the annulment stage, the setting aside stage and the vacation stage. Of the two regimes for enforcement of awards rendered in investment treaty arbitration, in fact only awards rendered in the proceedings with a seat are subject to control at the enforcement stage. Awards rendered in delocalised arbitration have to be enforced without any control whatsoever 'as if it were a final judgment of a court in that State' pursuant to Article 54 (1) of the ICSID Convention. The grounds for non-enforcement of awards with a seat are defined by the New York Convention or other applicable regional treaties. Article V of the New York Convention specifies grounds for non-enforcement because of the most fundamental violations pertaining to the tribunal's jurisdiction, due process, arbitrability and public policy. Contract interpretation does not appear independently as a protectable value and may only fall within the scope of review at the enforcement stage indirectly when the grounds for non-enforcement under the New York Convention or a relevant regional treaty are triggered. One may, for instance, attempt to resist enforcement of an award pertaining to the application of national law to contract interpretation if a tribunal unjustifiably excludes evidence in this regard, depriving a party of the opportunity of presenting its case and thus triggering a violation of due process. Similarly to annulment and setting aside procedures, the threshold for non-enforcement is necessarily high, making it absolutely important to be correct from the very beginning with regard to the determination and application of national law to contract interpretation in investment treaty arbitration.

In order to verify the limits of the control that domestic courts exercise in relation to contract interpretation at the enforcement stage, it may be interesting to look at all occasions of enforcement procedures in investment treaty arbitration. This is not feasible, however, within the framework of this work. ${ }^{214}$ At the same time, not as a substitution to full-scope research, but as

213 Ibid. para. 48 .

214 A study of all occasions of award enforcement in investment treaty arbitration requires substantial time, familiarity with legal regulation in various jurisdictions and in the absence of translations of the awards, proficiency in the language of the proceedings before the state courts, etc. It is not surprising that the broadest research to date in the field is conducted at the invitation of the local experts - see Julien Fouret (ed), Enforcement of Investment Treaty Arbitration Awards: A Global Guide (Globe Law and Business 2015). 
an illustration, it is possible to verify the limits on the example of one state. For this purpose, Ukraine may serve as a good case study. ${ }^{215}$ Out of the completed cases in which treaty-based tribunals have attempted to ascertain the content of contractual provisions to various extents, six cases involved Ukraine. ${ }^{216}$ Three of these cases - Inmaris Perestroika v. Ukraine, Alpha Projektholding v. Ukraine, Joseph Charles Lemire v. Ukraine - resulted in awards being rendered against Ukraine and thus potentially motivating the state to consider all possible grounds for non-enforcement. Of the three cases, only Inmaris Perestroika v. Ukraine was conducted in the proceedings with the seat and thus subject to the New York Convention at the stage of enforcement. The tribunal interpreted various contracts pertaining to a bareboat charter. The state, however, chose not to oppose enforcement. ${ }^{217}$ In Joseph Charles Lemire v. Ukraine the state abandoned all attempts to oppose the irregularities in contract interpretation demonstrated in the annulment stage and performed the award voluntarily, ${ }^{218}$

215 With 23 cases in which Ukraine appears as a respondent at the time of this study, the country has become among the most sued in investment treaty arbitration. See the statistics at UNCTAD Investment Policy Hub available at <https://investmentpolicy.unctad. org/investment-dispute-settlement $>$, last accessed 27 August 2020. Not least relevant for the choice of Ukraine is the fact that the author of this work is admitted to practise law in Ukraine and can therefore verify all publicly available information on the enforcement of arbitral awards.

216 Inmaris Perestroika Sailing Maritime Services GmbH and others v. Ukraine, ICSID Case No. ARB / O8/8, Excerpts of Award dated 1 March 2012, para. 400-410; Decision on Jurisdiction dated 8 March 2010, para. 37-44; Alpha Projektholding GmbH v. Ukraine, ICsID Case No. ARB / 07/16, Award dated 8 November 2010, para. 149-514; Joseph Charles Lemire v. Ukraine, ICSID Case No. ARB/o6/18, Decision on Jurisdiction and Liability dated 14 January 2010, para. 61, 65, 73-83, 105-196; Award dated 28 March 2011, para. 81-91, 184-185, Excerpts of Decision on Annulment dated 8 July 2013, para. 201, 220-230; Generation Ukraine, Inc. v. Ukraine, ICSID Case No. ARB/oo/9, Award dated 16 September 2003 para. 18.23-18.42; Bosh International, Inc and B\&P Ltd Foreign Investments Enterprise v. Ukraine, ICsID Case No. ARB / o8/11, Award dated 25 October 2012, para. 253-259; GEA Group Aktiengesellschaft v. Ukraine, ICsid Case No. ARB / o8/16; Award dated 31 March 2011, para. 145-164.

217 Inmaris Perestroika v. Ukraine, Decision of the Pechersky District Court of Kyiv 26 September 2012, Case № 2-K-14/12 available at <http://www.reyestr.court.gov.ua/Rev iew/26148630 $>$, last accessed 25 June 2021.

218 The excerpts of the Decision on Ukraine's Application for Annulment of the Award that are available in Joseph Charles Lemire v. Ukraine, ICSID Case No. ARB/O6/18 enable one to understand the arguments raised in respect to interpretation of the settlement agreement at the annulment. On Ukraine's voluntary performance of the award, see Tatyana Slipachuk and Olesia Gontar, 'Investment Treaty Arbitration in Ukraine' available at $<$ https://www.lexology.com/library/detail.aspx?g=52c75c3a-e528-4832-ad2f-141b3f8c9 e47>, last accessed on 25 June 2021. 
and in Alpha Projektholding v. Ukraine, the state did not oppose enforcement proceedings that were executed via the decision of the state court. ${ }^{219}$

\subsection{Conclusion}

An approach to contract interpretation that is built on a theory of the incidental issue in private international law provides an essential theoretical framework for answering the question of not only whether treaty-based tribunals can decide on subsidiary matters in relation to the principal question, such as contract interpretation, but also how they should exercise their jurisdiction and what the ultimate effects of decisions on incidental issues are. Rather than being just a mechanical separation of the issues because of their role with respect to the cause of action, the incidental issue appears as an essential theoretical framework capable of safeguarding its distinguishable legal nature and ensuring application of the proper law to it.

By proposing a theoretical paradigm that recognises the legal nature of contract interpretation and focuses on the choice of national law that is applicable to it, this chapter gives a comprehensive response to the challenges surrounding ascertaining the content of contractual provisions in investment treaty arbitration. It is not sufficient to have incidental jurisdiction or power to ascertain the content of contractual provisions; it is also important to exercise this jurisdiction by acknowledging the legal nature of contract interpretation as embedded in the law governing the contract, and to choose and apply the right national law to the analysis. Treating contract interpretation as the incidental issue ensures that the relevant national law will be applied, and all the necessary conditions are thus created for a correct outcome that is consistent with approaching the contract in the jurisdiction in which it was drafted and concluded.

No doubt, treating contract interpretation as the incidental issue is not the only precondition for finding the right solution. When tribunals ascertain the content of contractual provisions through instrumentalities other than the primary application of national law, such as fact-finding or via selective reliance on canons of interpretation that are not expressly linked with the national law applicable to the contract, the result can be the same as if national law had duly been applied. For instance, a contractual duty to make certain payments

219 Alpha Projektholding v. Ukraine, Decision of the Pechersky District Court of Kyiv 23 July 2011, Case № 2-K-7/11 available at <http://www.reyestr.court.gov.ua/Review/16679895>, last accessed on 25 June 2021. 
can acquire a similar effect in investment treaty arbitration if tribunals justify reasoning based on fact-finding by simply stating 'what stands in the contract'. They may achieve a similar effect by relying on the effet utile canon without any substantiation based on the applicable national law by simply saying that words in the contract are to be valued and not ignored. They can also expressly refer to the applicable national law and emphasise that their interpretation is mainly shaped by an ordinary understanding of the text as a primary source for its interpretation. Also, it is highly likely that the same result will be achieved when approaches that are not informed by the relevant national law endorse textualism or literalism, and when the text itself is sufficiently detailed.

The results may differ dramatically, however, on extreme occasions. By extreme occasions one may understand those situations when the text alone is not sufficient and the tribunal requires a broader context or when the tribunal has to deal with internal controversy within the contractual text, etc. In these situations, various interpretative paths may lead to different results and it would be crucial to rely on the applicable national law. Conceptualising contract interpretation as the incidental issue would ensure correct interpretation.

Even when the same result can be achieved without applying national law, there is still value in approaching contract interpretation as the incidental issue. Without the analytical paradigm of the incidental issue, treaty-based tribunals inevitably seek to anchor their decisions to the most convenient approach in the circumstances. Disengaged from national law canons of interpretation, fact-finding, business practices, trade usages - all may arise during tribunals' attempts to understand contracts. Even if authorised by national law and occasionally or predominantly leading to a correct outcome, these approaches will still lack the necessary predictability ensured by the primary or ab initio application of national law, with its normative legal frame for contract interpretation. The most important contribution of the concept of the incidental issue to decision-making in investment treaty arbitration is thus methodological clarity and predictability for understanding the content of contractual provisions that is based on due regard to its legal nature and the applicable national law.

Furthermore, conceptualising contract interpretation as the incidental issue enables justice to be done without blocking a procedure in investment treaty arbitration. Generally viewed, the concept of the incidental issue ensures that a court or a tribunal can decide on the issue for the purpose of its jurisdiction without waiting for the issue to be conclusively resolved as a principal one before another competent adjudicatory body. For investment treaty arbitration, an approach to contract interpretation as the incidental issue means that the jurisdiction of treaty-based tribunals is not blocked until the issue is resolved as the principal issue in the relevant contract-based procedures. The 
tribunals' decision on the content of contractual provisions thus rendered would not have the same final effect as the decisions of courts or tribunals that exercise contract interpretation in the framework of contractual claims as the principal issue. ${ }^{220}$ The differences in effect of contract interpretation decided as the incidental issue or a part of the principal issue opens a possibility for deference discussed in Chapter 4.

Finally, the theoretical frame of the incidental issue fits well into the publicprivate divide in investment treaty arbitration and enhances more structured decision-making that is informed by a comprehensive account of increasing interrelations and coordination between private law and public law as well as between private international law and public international law. ${ }^{221}$

220 The tribunal in Vigotop explained this by saying that 'any findings that this Tribunal may make in respect of the Concession Contract are relevant only as a part of the Tribunal's analysis of Claimant's expropriation claim' - see Vigotop Limited v. Hungary, ICsid Case No. ARB $/ 11 / 22$, Award dated 1 October 2014, para. 313.

221 On various aspects of distilling frontiers between private and public as well as between private international law and public international law see Veronica Ruiz Abou-Nigm, Kasey McCall-Smith and Duncan French (eds), Linkages and Boundaries in Private and Public International Law (Hart Publishing 2018); Horatia Muir Watt and others (eds), Global Private International Law Adjudication without Frontiers (Edward Elgar Publishing 2019); Roxana Banu, Nineteenth Century Perspectives on Private International Law (Oxford University Press 2018); Burkhard Hess, 'The Private-Public Divide in International Dispute Resolution' (2018) 388 Recueil des Cours de l'Académie de Droit International 49; Julian Arato, 'The Private Law Critique of International Investment Law' (2019) 113(1) American Journal of International Law 1; Alex Mills, The Confluence of Public and Private International Law: Justice, Pluralism and Subsidiarity in the International Constitutional Ordering of Private Law (Cambridge University Press 2009). 